ALFREDO CARLOS RODRIGUES FEITOSA

\title{
AVALIAÇÃO CLÍNICA E MICROBIOLÓGICA EM PUÉRPERAS COM DOENCAA PERIODONTAL E A SUA RELAÇÃO COM DESFECHO REPRODUTIVO RUIM
}

Tese apresentada ao Programa de Pósgraduação em Microbiologia do Instituto de Ciências Biomédicas da Universidade de São Paulo para obtenção do Título de Doutor em Ciências.

São Paulo

2011 


\section{AVALIAÇÃO CLÍNICA E MICROBIOLÓGICA EM PUÉRPERAS COM DOENCAA PERIODONTAL E A SUA RELAÇÃO COM DESFECHO REPRODUTIVO RUIM}

Tese apresentada ao Programa de Pósgraduação em Microbiologia do Instituto de Ciências Biomédicas da Universidade de São Paulo para obtenção do Título de Doutor em Ciências.

Área de Concentração: Microbiologia.

Orientador: Prof. Dr. Mario Julio Avila-Campos.

Versão corrigida. A versão original se encontra arquivada no Serviço de Comunicações do ICB.

São Paulo

2011 
DADOS DE CATALOGAÇÃO NA PUBLICAÇÃO (CIP)

Serviço de Biblioteca e Informação Biomédica do

Instituto de Ciências Biomédicas da Universidade de São Paulo

(C) reprodução total

Feitosa, Alfredo Carlos Rodrigues.

Avaliação clínica e microbiológica em puérperas com doença periodontal e a sua relação com desfecho reprodutivo ruim / Alfredo Carlos Rodrigues Feitosa. -- São Paulo, 2011.

Orientador: Mario Julio Avila-Campos.

Tese (Doutorado) - Universidade de São Paulo. Instituto de Ciências Biomédicas. Departamento de Microbiologia. Área de concentração: Microbiologia. Linha de pesquisa: Bacteriologia de anaeróbios.

Versão do título para o inglês: Clinical and microbiological evaluation in pregnants with periodontal disease and its relation to perinatal adverse outcome.

Descritores: 1. Periodontite 2. Bactérias 3. Porphyromonas gingivalis 4. Corioamnionite 5. Placenta 6. Membranas fetais I. Avila-Campos, Mario Julio II. Universidade de São Paulo. Instituto de Ciências Biomédicas. Programa de Pós-Graduação em Microbiologia III. Título. 


\section{UNIVERSIDADE DE SÃO PAULO \\ INSTITUTO DE CIÊNCIAS BIOMÉDICAS}

Candidato(a):

Título da Tese:

Orientador(a):
Alfredo Carlos Rodrigues Feitosa.

Avaliação clínica e microbiológica em puérperas com doença periodontal e a sua relação com desfecho reprodutivo ruim.

Mario Julio Avila Campos.

A Comissão Julgadora dos trabalhos de Defesa da Tese de Doutorado, em sessão pública realizada a considerou

\section{( ) Aprovado(a) ( ) Reprovado(a)}

Examinador(a): Nome completo:

Instituição:

Examinador(a): Nome completo:

Instituição:

Examinador(a): Nome completo:

Instituição:

Examinador(a): Nome completo:

Instituição:

Presidente: Nome completo:

Instituição: 
São Paulo, 04 de outubro de 2007.

\section{PARECER 807/CEP}

Prezado Senhor

Atendendo sua solicitação, a Comissão de Ética em Pesquisas com Seres Humanos do ICB, em sua $79^{\circ}$ reunião realizada em 03.10 .07 , analisou o projeto de sua responsabilidade intitulado: "Avaliação Microbiológica da doença periodontal e da Placenta de parturientes atendidas em Hospitais Públicos de Vitória-Es".

Informo a V.Sa. que, após análise e discussão o referido projeło foi aprovado por esta Comissão.

Lembramos que cabe ao pesquisador elaborar e apresentar a este Comitê, relatórios anuais (parciais ou final), de acordo com a resolução 196/06 do Conselho Nacional da Saúde, item IX.2 letra c.

O primeiro relatório deverá ser encaminhado à Secretaria deste CEP em 03 de outubro de 2008.

Atenciosamente,

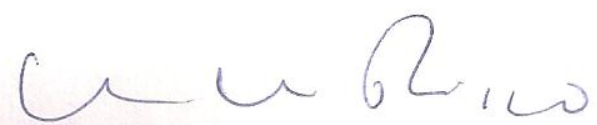

Prof. Dr. LUIZ VICENTE RIZZO

Coordenador da Comissão de Ética em Pesquisas com Seres Humanos - ICB /USP

IImo. Sr.

ALFREDO CARLOS RODRIGUES FEITOSA

Departamento de Microbiologia

Instituto de Ciências Biomédicas -USP 


\section{Meu agradecimento especial}

À minha esposa, Edna Maria Lorenzoni Feitosa, pela sua infinita compreensão nas minhas constantes ausências como esposo, companheiro, amigo e pai na concretização deste sonho, assim como, pelo desprendimento de horas preciosas de convívio nesta fase, pelos seus conselhos, pelos estímulos constantes recebidos para o meu desenvolvimento profissional e pessoal e pela sua amizade e amor eternos.

À minha amada filha, Loise Lorenzoni Feitosa, pela doçura do seu amor de inocência transmitido a mim, nas duras e longas caminhadas longe de ti, mas que sempre respondeu com amor, carinho e atenção.

Ao meu pai, Wildon Feitosa (in memorian) e à minha mãe, Layr Rodrigues Feitosa, pelo apoio incondicional durante toda essa caminhada profissional, pelos ensinamentos e princípios de família fundamentais, e pelo amor, carinho, e coragem para prosseguir com os meus sonfos.

Aos meus amados irmãos, Marco Antonio Rodrigues Feitosa e Família, Ana Cristina Rodrigues Feitosa e Família, Karla Mariana Feitosa Oliveira e Família, Wildon Feitosa Filho (in memorian), Guilherme Rodrigues Feitosa e Família pela força e compreensão durante toda esta jornada.

Aos amigos, Roberto William Oliveira Ruy, sua esposa, Lúcia Lorenzoni Ruy e seus filhos, Tiago Lorenzoni Ruy, Bruno Lorenzoni Ruy e Mayara Lorenzoni Ruy pelo constante e profícuo apoio durante a minha ausência e acolhimento carinhoso e gratuito da minha pequena família no desfrute da amizade ao longo destes anos. 


\section{AGRADECIMENTOS}

Primeiramente a Deus, pelas bênçãos recebidas e pela minha salvação, pois sem Sua presença em minha vida, eu nada seria.

Ao meu Orientador, Professor Doutor Mario Julio Avila-Campos, pelo seu apoio, estímulo constante, compreensão e interesse em meu desenvolvimento profissional para a execução desta pesquisa. Professor amante da pesquisa e da ciência, de espírito renovador e dedicação à Universidade de São Paulo. Seu equilíbrio e amizade ao longo de todos estes anos foram fundamentais em todos os momentos. Muito obrigado por ter acreditado em mim e por esta oportunidade acadêmica.

Ao Professor Doutor Paulo Roberto Merçon de Vargas, por ter compartilhado com suas brilhantes idéias no planejamento deste trabalho. Muito obrigado pela oportunidade de tê-lo neste projeto e, ainda, na academia da Universidade Federal do Espírito Santo.

A todas as puérperas que participaram deste estudo, pelo interesse e simpatia e confiança, cedendo momentos preciosos e muitas vezes difíceis de suas vidas no contexto da maternidade e do trabalho de parto durante a execução das entrevistas e do exame clínico periodontal. A elas, meu sincero reconhecimento.

À Universidade Federal do Espírito Santo, em especial, ao Reitor, Professor Dr. Rubens Sérgio Rasseli, ao Vice-Reitor, Professor Dr. Reinaldo Centoducate pelos constantes incentivos recebidos durante minha ausência.

Ao Diretor e Vice-Diretora do Centro de Ciências da Saúde, Professor Dr. Carlos Alberto Redins e Professora Drạ. Hermenegilda Grasseli Batitucci pelo apoio à dedicação dos meus estudos na Universidade de São Paulo.

Ao Diretor Superintendente do Hospital Universitário Cassiano Antonio de Moraes/HUCAM, Dr. Emílio Mameri e ao Diretor Clínico, Dr. Wilson Zanotti pela oportunidade de conhecer e partilhar este projeto com a equipe deste Hospital.

Ao Dr. Luiz Carlos Sobral Vieira Jr. pela viabilidade de execução deste projeto junto a Maternidade Hospital Universitário Cassiano Antonio de Moraes/HUCAM. 
Ao Diretor-Superintendente do Instituto de Odontologia, Prof. Dr. Ranulfo Gianórdoli Neto pela sua extrema boa vontade em disponibilizar espaços físicos para o exame clínico nas puérperas.

Aos Professores do Departamento de Clínica Odontológica da Universidade Federal do Espírito Santo, e em especial, à Professora Mestre Maria Rebeca Amaral Ganhoto pelo apoio acadêmico durante o meu afastamento para melhoria da qualidade docente desta instituição de ensino superior.

Aos colegas médicos do Serviço de Patologia do HUCAM pela atenção acadêmica e profissional dispensados a mim em todos os momentos que eu precisei estar com vocês durante a execução desta pesquisa, em especial, Dr. Adauto Persici, Drª. Helena Lucia Barroso dos Reis, Drª ${ }^{\mathrm{a}}$, Carla Regina Santos De Carli e Drª . Laura Fregonassi Ribeiro.

Ao cirurgião-dentista, Felipe de Oliveira Kiepper pela agradável companhia nas visitas ao HUCAM para registro dos dados hospitalares, coletas das amostras, exames clínicos periodontais, transporte e armazenamento das amostras.

A todos os funcionários do Serviço de Esterilização da Maternidade do HUCAM pelas facilidades no pronto atendimento na limpeza, esterilização, e armazenamento dos materiais odontológicos utilizados para a coleta dos espécimes bucais, e, em especial, à técnica de Enfermagem, Sra. Maria da Glória Reis Chagas pelo apoio no transporte das placentas para o Serviço de Patologia.

Aos meus colegas do Laboratório de Anaeróbios do Departamento de Microbiologia da Universidade de São Paulo, Dr. Elerson Gaetti Jardim Junior, Drª . Viviane Nakano Katz, Dr. Antonio Scalco Fabris, Dr. Vitor Rafael Castillo Merino, Drª . Thais Cristiane Wahasugui, Drª . Sheila Alexandra Belini Nishiyama, Dra . Viviane Aparecida Arenas Rodrigues, Dr. Luiz Antonio Llanco Albornoz, acadêmica Aline Ignácio Silvestre da Silva e à técnica, Zulmira Alves Souza e demais colegas, pelas incontáveis ajudas no preparo dos protocolos laboratoriais exigidos neste trabalho e pela alegria e amizade dividida em todos os momentos.

Agradeço aos atuais alunos e antecessores do Serviço de Patologia do HUCAM sob orientação do Professor Dr. Paulo Roberto Merçon de Vargas que dedicaram horas de análise, planejamento, montagem e execução dos dados desta pesquisa tornando viável a utilização de todo este material, especialmente aos 
doutorandos de Medicina, Antonio Alfim Malandrini Ribeiro pela conferência na reprodutibilidade das aferições; Karina da Silva Araújo, pela ajuda no levantamento de casos nos arquivos do Serviço de Patologia e na elaboração dos gráficos ramo-efolha; Lissa Severo Sakugawa e a Paulo Henrique Oliveira de Souza pelo auxílio no levantamento dos casos nos arquivos do Serviço de Patologia; Rafaela Batisti Nery, pela coordenação e organização dos dados, Rafael Calil Salim, pelo brilhante trabalho fotográfico, Daniel Ribeiro da Rocha, pela busca e organização das referências bibliográficas, à técnica, Solange Raquel de Carvalho pelo auxílio no preparo das lâminas e a Cristiane Borba, secretária e técnica do laboratório PAT pela gentileza no processamento histológico.

Ao Núcleo de Doenças Infecciosas, NDI, em especial, aos Professores, Dr. Reinaldo Dietzie (Coordenador Geral) e Dr. Rodrigo Ribeiro Rodrigues por terem cedido o laboratório para armazenamento das amostras.

Aos servidores técnicos do Instituto de Odontologia da UFES/IOUFES e servidores terceirizados, Carlos Alberto Loiola, Clebson Rodrigues, Cleonis Rodrigues, Deuza Lucindo dos Santos, Iracy do Carmo Oliveira, Ivanete Bernardo Rosendo, José Carlos Guterres Rosetti, Maria Natalina Tonoli Santiago, Marcos Araújo Cândido, Maria de Lourdes Bravim Calil, Stefania Louise, Rosemary dos Santos Pereira, e, Zenaide da Silva Oliveira Porchera, pela atenção dispensada em sempre disponibilizar um tempinho para me ajudar na esterilização, ou na compra de algum material permanente, no lanche, água, café e biscoito nos momentos mais críticos durante as minhas visitas no HUCAM.

Finalmente, a todos aqueles que efetivamente contribuíram de forma direta ou indireta para o meu êxito na obtenção deste título acadêmico. Posso ter omitido alguém, com estes, desculpo-me. Muito obrigado a todos pelo valioso auxílio prestado e pela excelente convivência durante todo este período de estudos. 
"Existe uma cortesia do Coração que ao amor se Irmana. Dela flui a cortesia serena da conduta exterior."

Goethe 


\section{LISTA DE ILUSTRAÇÕES}

Fluxograma 1 - Material clínico coletado de diferentes fontes e a possível relação com desfechos reprodutivos e infecciosos. 46

Fluxograma 2 - Momento da coleta dos diferentes espécimes clínicos entre as puérperas do HUCAM................................................

Figura 1 - Desenho esquemático da placenta e dos sítios coletados...47

Figura 2 - Coleta da membrana amniônica............................................47

Figura 3 - Coleta de parênquima placentário.........................................48

Figura 4 - Biofilme subgengival coletado com cones de papel inseridos na bolsa periodontal.

Figura 5 - Distribuição da profundidade de bolsa e do nível clínico de inserção.

Figura 6 - Presença de algum periodontopatógeno em qualquer sítio avaliado.

Figura 7 - Presença de bactérias periodontopatogênicas nas amostras de biofilme subgengival.

Figura 8 - Presença de bactérias periodontopatogênicas nas amostras vaginais

Figura 9 - Presença de bactérias periodontopatogênicas nas amostras amnióticas.

Figura 10 - Presença de bactérias periodontopatogênicas nas amostras de placenta. 59

Figura 11 - Presença de $P$. gingivalis em dois sítios analisados..........60

Figura 12 - Presença de F. nucleatum nos sítios analisados................61

Figura 13 - Presença de T. forsythia nos sítios analisados...................61

Figura 14 - Início de trabalho de parto nas terminações a termo..........62

Figura 15 - Rotura prolongada das membranas fetais..........................63

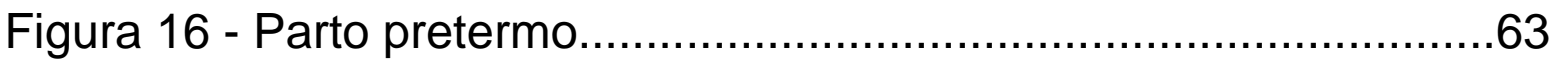




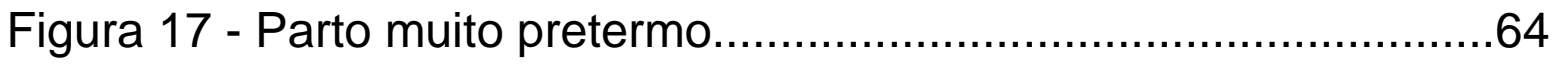

Figura 18 - Baixo peso fetal ao nascer...........................................64

Figura 19 - Alguma (qualquer) bactéria periodontopatogênica em âmnio

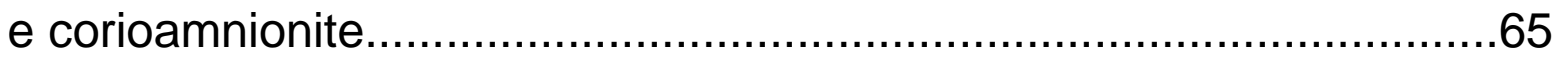

Figura 20 - Corioamnionite...........................................................66

Figura 21 - $P$. gingivalis no âmnio e corioamnionite..........................66

Figura 22 - P. gingivalis no âmnio e corioamnionite...........................67 


\section{LISTA DE TABELAS}

Tabela 1 - Bactérias alvo, sequência de primers, condições, temperatura de anelamento, pares de base e referência.....................51

Tabela 2 - Dados demográficos, gestacionais, obstétricos e fetais......53

Tabela 3 - Dados clínicos bucais....................................................54

Tabela 4 - Distribuição topográfica de bactérias periodontopatogênicas em 93 puérperas..............................................................................56 


\section{LISTA DE ABREVIATURAS E SIGLAS}

A.actinomycetemcomitnas - Aggregatibacter actinomycetemcomitans

ATCC - American Type Culture Collection

b - tipo de sorotipo da bactéria A.actinomycetemcomitans

BANA - N-benzoyl-DL-arginine-2-naphthylamide

BPN - Baixo peso fetal ao nascer

BPPG - Bactéria periodontopatogênica

CAM - Corioamnionite

CEP - Comitê de ética em pesquisa

DNA - Ácido desoxirribonucléico

dNTP - Mistura de nucleotídeos (dATP,dCTP,dGTP,dTTP)

DP - Doença periodontal

DRR - Desfecho reprodutivo ruim

ES - Estado do Espírito Santo

F.nucleatum - Fusobacterium nucleatum

FNTa - Fator de necrose tumoral alfa

HUCAM - Hospital Universitário Cassiano Antonio de Moraes

IC - Intervalo de confiança

ID - Incremento direto

IG - Idade gestacional

IgM - Imunoglobulina M 
IL-1 - Interleucina 1

IOUFES - Instituto de Odontologia da Universidade Federal do Espírito Santo

IPV - Índice de placa visível

IQR - Interquartil range

ISG - Índice de sangramento gengival

$\mathrm{Kb}$ - kilobase

LPS - Lipopolissacarídeo

MPN - Morte perinatal

$\mathrm{NCl}$ - Nível clínico de inserção

NDI - Núcleo de doenças infecciosas

NNE - Número necessário para efeito

OR - Odds ratio

p - Valor p (significância)

PAT - Laboratório de Patologia

PB - Profundidade de bolsa

PCR - Reação em cadeia da polimerase

PG - Prostaglandina

PGE2 - Prostaglandina E2

PS - Profundidade de sondagem

PPT - Parto pretermo

PCPUNC-BR - Periodontal Carolina Probe University of North CarolinaBrasil 
P.gingivalis - Porphyromonas gingivalis

PROM - Rotura prematura de membranas fetais

PPROM - Rotura precoce e prematura de membranas fetais

PTBPN - Pretermo e baixo peso fetal ao nascer

PT - Parto a termo

SINASC - Sistema de Informações de Nascidos Vivos

SS - Sangramento à sondagem

SUP - Supuração

SUS - Sistema Único de Saúde

Taq-Enzima Taq polimerase (Thermus aquaticus)

TE - Tampão Tris-HCl-EDTA

T.forsythia - Tannerella forsythia

TPPT - Trabalho de parto pretermo

TPPT - PPT - Trabalho de parto pretermo e parto pretermo

UFES - Universidade Federal do Espírito Santo

V - Volts

VB - Vaginose bacteriana

$X^{2}$ - Qui quadrado

Y4 - tipo de sorotipo da bactéria Aggregatibacter actinomycetemcomitans 


\section{SUMÁRIO}

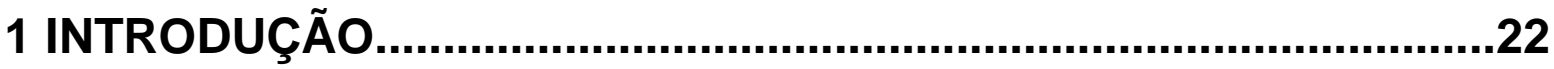

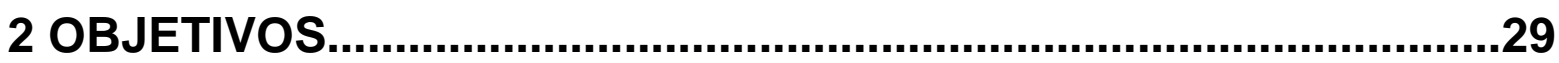

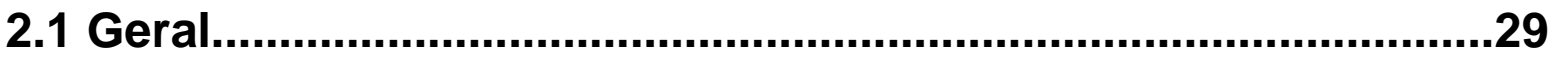

2.2 Específicos..............................................................................29

3 REVISÃO DE LITERATURA........................................................30

3.1 A Doença periodontal.................................................................

3.2 A Inflamação na doença periodontal...........................................31

3.3 Relações entre periodontopatógenos, doença periodontal e desfecho reprodutivo ruim.................................................................32

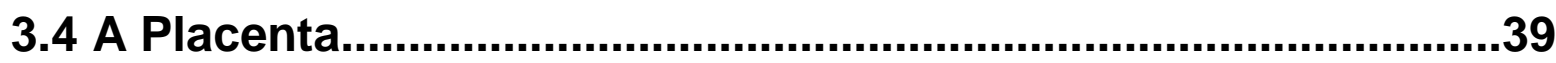

3.4.1 A Inflamação na placenta..........................................................39

3.4.2 Microbiota vaginal e sua relação com o tipo de parto e com a corioamnionite.

3.4.3 A Invasão microbiana da cavidade amniótica.........................42

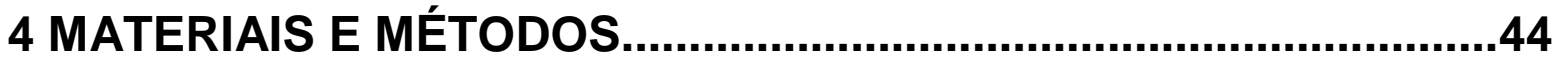

4.1 Seleção de paciente......................................................................44

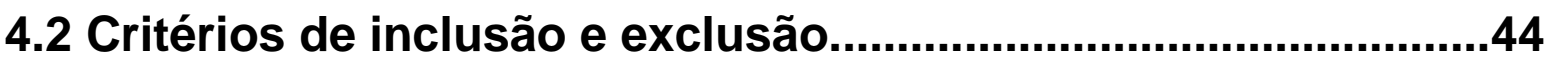

4.3 Processamento histopatológico...................................................44

4.4 Procedimentos clínicos............................................................44

4.4.1 Informações médicas-obstétricas...........................................44 
4.5 Coletas das amostras e os momentos de amostragem .

4.5.1 Cavidade bucal......................................................48

4.5.1.1 Biofilme subgengival..............................................................48

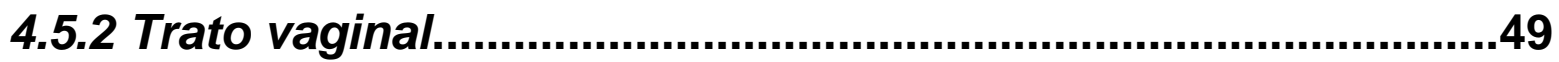

4.5.2.1 Secreção cérvico-vaginal........................................................49

4.5.3 Placenta e âmnio....................................................................49

4.5.3.1 Exame anátomo-patológico dos anexos fetais..........................49

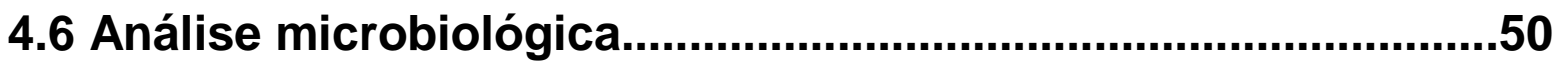

4.6.1Extração de DNA bacteriano das amostras clínicas................50

4.6.2 Deteç̧ão bacteriana pela reação em cadeia da polimerase

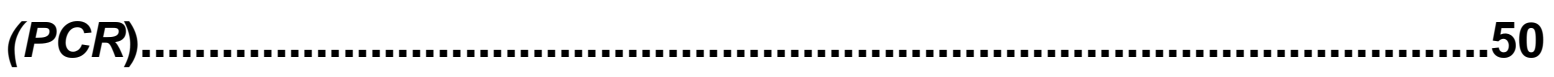

4.7 Análise estatística....................................................................51

4.8 Implicações éticas.............................................................52

5 RESULTADOS.............................................................................53

5.1 Dados demográficos, obstétricos e fetais................................53

5.2 Dados clínicos bucais.................................................................54

5.3 Prevalência de bactéria periodontopatogênica (BPPG)............55

5.4 Disseminação de bactéria periodontopatogênica.....................59 
5.4.1 Disseminação da boca para a vagina. 59

5.4.2 Disseminação da boca para o âmnio. .60

5.4.3 Disseminação da boca para o parênquima placentário. .60

5.4.4 Disseminação da vagina para o âmnio. .61

5.4.5 Disseminação do âmnio para o parênquima placentário 61

5.5 Associações entre doença periodontal, bactérias periodontopatogênicas e desfechos reprodutivos ruins (DRR).....62

5.5.1 Doença periodontal e desfechos reprodutivos ruins. .62

5.5.2 Bactérias periodontopatogênicas e desfechos reprodutivos ruins. .65

6 DISCUSSÃO. .68

7 CONCLUSÕES. .82

REFERÊNCIAS. .83 APÊNDICES 


\section{RESUMO}

Feitosa, ACR. Avaliação clínica e microbiológica em puérperas com doença periodontal e a sua relação com desfecho reprodutivo ruim. [Tese (Doutorado em Microbiologia)]. São Paulo: Instituto de Ciências Biomédicas da Universidade de São Paulo; 2011.

A doença periodontal é uma inflamação crônica dos tecidos periodontais causada por bactérias presentes no biofilme dentário, manifestando-se como gengivite ou periodontite e decorrente de uma complexa interação entre a microbiota e a resposta do hospedeiro. Tem sido postulada uma possível relação causal entre doença periodontal materna e desfecho reprodutivo ruim (parto pretermo, baixo peso fetal e morte perinatal), corioamnionite e vilosite. Este estudo analisou a prevalência de doença periodontal e de periodontopatógenos nos sítios relacionados com as vias ascendente (boca para vagina e âmnio) e hematogênica (boca para parênquima placentário) da infecção dos anexos fetais, visando relacioná-los com corioamnionite e desfecho reprodutivo ruim. Dados clínicos obstétricos e periodontais e amostras do biofilme subgengival, conteúdo vaginal, âmnio e parênquima da placenta foram obtidos de 93 puérperas atendidas no hospital universitário público terciário, em Vitória, ES. Porphyromonas gingivalis, $A$. actinomycetemcomitans, F. nucleatum e T. forsythia foram identificadas pela reação em cadeia da polimerase, o diagnóstico de CAM e vilosite estabelecidos por histopatologia, e as relações com o desfecho reprodutivo ruim, analisadas pelo incremento direto e odds ratio. Os casos estudados apresentavam o típico perfil das gestantes brasileiras atendidas pelo SUS: 20,4\% eram adolescentes, $75 \%$ negras, $79,6 \%$ com menos de oito anos de educação, 31,2\% ocupavam-se do lar, $70,6 \%$ não civilmente casadas, $10,8 \%$ atenderam menos de quatro consultas prenatais e 55,9\% eram primigestas. Rotura prematura ou precoce de membranas foi observada em $22,2 \%$, parto cesariano em $65,6 \%$, pretermo em $36,6 \%$, baixo peso fetal em 34,4\%, morte perinatal em 5,4\%; corioamnionite em 34,4\% e vilosite em $5,5 \%$ dos casos. Todas apresentavam alguma doença periodontal e $62,4 \%$ sua forma agressiva, com profundidade de bolsa mediana de 4,6 mm e nível clínico de inserção mediano de 3,8 mm; 72,04\% já haviam perdido algum dente e 83,87\% tinham cárie. Neste estudo, a presença de periodontite ou periodontopatógenos em 
qualquer sitio não se associou com maior freqüência ou com maior risco de corioamnionite ou de desfecho reprodutivo ruim. No biofilme subgengival observouse a presença de A.actinomycetemcomitans em duas puérperas $(2,1 \%)$, F.nucleatum em 16 (17,20\%), P.gingivalis em 30 (32,30\%) e T.forsythia em 29 (31.2\%); na vagina, A.actinomycetemcomitans em três (3,2\%), F.nucleatum em duas $(2,1 \%)$, P.gingivalis em $16(17,2 \%)$ e T.forsythia em três $(3,2 \%)$; no âmnio, F.nucleatum em quatro (4,2\%) e P.gingivalis em nove (9,7\%); na placenta, F.nucleatum em uma puérpera (1,07\%), P.gingivalis em quatro $(4,3 \%)$ e T.forsythia em uma puérpera $(1,1 \%)$. Apenas $P$. gingivalis e $F$. nucleatum foram concomitantemente observados em dois ou mais sítios, como segue: de 30 puérperas com P.gingivalis em boca, em seis $(20,0 \%)$ foram detectadas na vagina, três $(10,00 \%)$ no âmnio e uma (3,33\%) na placenta; das 16 com F.nucleatum em boca, apenas uma $(6,25 \%)$ foi encontrada na placenta. Esta pequena taxa de disseminação sugere que a maioria das bactérias periodontais presente na vagina, âmnio ou placenta não se originou na boca das puérperas, uma hipótese que necessita futuros estudos.

Palavras-chave: Periodontite. Bactérias periodontais. Corioamnionite. Placenta. Membranas fetais. Prematuridade. 


\begin{abstract}
Feitosa, ACR. Clinical and microbiological evaluation in pregnants with periodontal disease and its relationship to perinatal adverse outcome. [Ph. D. thesis (Microbiology)]. São Paulo: Instituto de Ciências Biomédicas da Universidade de São Paulo; 2011.
\end{abstract}

Periodontal disease is a chronic inflammation of periodontal tissues caused by bacteria in dental plaque, manifesting as gingivitis or periodontitis and results from a complex interaction between the microbiota and host response. It has been postulated a possible causal relationship between maternal periodontal disease and adverse perinatal outcome (APO: preterm delivery, low fetal weight and perinatal death), and chorioamnionitis and villitis. This study examined the prevalence of periodontal disease and periodontopathogens (PPG) related sites in the ascending pathways (mouth to vagina and amnion) and hematogenous (mouth to placental parenchyma) infection of fetal adnexal in order to relate them to outcome and chorioamnionitis (CAM) adverse perinatal was determined. Obstetrics and periodontal clinical samples, vaginal contents, amnion and placental parenchyma were obtained from 93 pregnant visiting a tertiary public university hospital (Vitoria, ES, Brazil). Porphyromonas gingivalis, Aggregatibacter actinomycetemcomitans, Fusobacterium nucleatum, and Tannerella forsythia were identified by polymerase chain reaction (PCR), the diagnosis of CAM and villitis established by histopathology methods and its relationships with APO analyzed by increasing direct and odds ratio. The case studies showed the typical profile of Brazilian pregnant women attended by SUS: $20.4 \%$ were teenagers, $75.0 \%$ nonwhite, $79.6 \%$ with less than 8 years of education, $31.2 \%$ took care of the home, $70.6 \%$ did not civilly married, $10.8 \%$ attended fewer than 4 prenatal visits and $55.9 \%$ were primigravidae. Early or premature rupture of membranes was observed in $22.2 \%$, cesarean delivery in $65.6 \%, 36.6 \%$ in preterm, low fetal weight by $34.4 \%$, perinatal death in $5.4 \%$, chorioamnionitis in $34.4 \%$, and villitis in $5.5 \%$ of cases. All of them had some form of periodontal disease and $62.4 \%$ aggressive periodontitis, with median pocket depth of $4.6 \mathrm{~mm}$ and clinical attachment level median of $3.8 \mathrm{~mm}, 72.04 \%$ had lost a tooth and $83.87 \%$ had caries. In this study, periodontitis or periodontopathogen in any site not associated with greater frequency or at greater risk of chorioamnionitis or APO was observed. In the subgingival biofilm A.actinomycetemcomitans was observed in 2 (2.1\%), F.nucleatum in 16 (17.20\%), P.gingivalis in 30 (32.30\%) and T.forsythia in 29 (31.2\%); in the vagina, 3 in A.actinomycetemcomitans (3.2\%), F.nucleatum in $2(2.1)$, P.gingivalis in $16(17.2 \%)$ and T.forsythia in 3 (3.2\%); amnion, F.nucleatum in 4 $(4.2 \%)$ and P.gingivalis in 9 (9.7\%); in the placenta, F.nucleatum in $1(1.07 \%)$, P.gingivalis in $4(4.3 \%)$ and T.forsythia in only one puerperae $(1.1 \%)$. Only F.nucleatum and P.gingivalis were observed simultaneously in two or more sites: 30 mothers with $P$.gingivalis in the mouth, $6(20.0 \%)$ were detected in the vagina, 3 $(10.0 \%)$ in amnion and 1 (3.33\%) in the placenta; F.nucleatum with 16 in the mouth, only $1(6.25 \%)$ was found in the placenta. This low rate of spread suggests that most of periodontopathogens present in vagina, amnion or placenta did not belong to the pregnant mouth, a hypothesis that needs further studies. 
Keywords: Periodontitis. Periodontal bacteria. Chorioamnionitis. Placenta. Fetal membranes. Prematurity. 


\section{INTRODUÇÃO}

A doença periodontal (DP) é uma inflamação crônica dos tecidos periodontais causada por bactérias presentes no biofilme dentário (Löe et al., 1965; Haffajee e Socransky, 1994; Haffajee e Socransky, 2005; Page 1986; Sakamoto et al., 2005; Socransky e Haffajee, 1994; Socransky et al., 1998; Socransky e Haffajee, 2005). Sua gravidade e manifestações clínicas, gengivite, periodontite e eventual perda de elementos dentários, decorrem de uma complexa interação entre a microbiota e a resposta do hospedeiro (Haffajee e Socransky, 2001; Schenkein, 2002; Socransky e Haffajee, 1994).

Tem sido postulado, recentemente, que patógenos oportunistas da microbiota bucal e de outros sítios corporais exercem efeitos sobre o trabalho de parto prematuro por meio da via hematogênica. Vários microrganismos oriundos de uma fonte não genito-urinária têm sido cultivados de infecções amnióticas. Entre esses, destacam-se, Fusobacterium nucleatum, Porphyromonas spp., Prevotella spp., Peptostrepotococcus spp., Eubacterium spp. e Eikenella corrodens. Além disso, F. nucleatum uma espécie residente da cavidade bucal, é a mais freqüentemente isolada de líquido amniótico entre mulheres com trabalho de parto pretermo e com membranas fetais intactas (Hill, 1988). Além dos efeitos locais de um foco infeccioso, a doença periodontal pode associar-se com manifestações em sítios distantes ou sistêmicos (Libby et al., 1997). Deste modo, as bactérias encontradas na boca podem alcançar o líquido amniótico via corrente sanguínea, particularmente na presença de gengivite ou periodontite durante a gestação (Kornman e Löesche, 1980). Por sua vez, os sintomas e alterações hormonais que ocorrem na gestação parecem agravar o processo infeccioso periodontal, requerendo cuidados 
específicos no pré-natal (Calabrich e Calabrich, 2005).

A possibilidade de a doença periodontal causar desfecho reprodutivo ruim (DRR) tem sido descrita na literatura como parto pretermo (PPT, antes de 37 semanas de gestação) ou prematuridade, baixo peso fetal ao nascer (BPN<2500g), infecção perinatal, morbidade e morte perinatal (MPN), e foi iniciado com os estudos de Offenbacher et al. (1996a), que demonstraram que gestantes com doença periodontal apresentavam 7,5 vezes mais chances de conceber crianças prematuras ou com BPN.

Em conjunto, parto pretermo e baixo peso fetal ao nascer constituem um dos mais importantes determinantes de morbidade e morte perinatal (Naeye e Tafari, 1983) sendo considerado também, um dos maiores desafios da obstetrícia contemporânea (Nordenvall e Sandstedt, 1990).

Nos países desenvolvidos, a prevalência de parto pretermo varia de 8 a $10 \%$ das gestações (Berkowitz e Papiernik, 1993), em contraste com a América Latina em que varia entre 10 e 43\% (Althabe e Schwarcz, 1978). Os dados do Ministério da Saúde (Sinasc) para o ano 2005, no Brasil, no Estado do Espírito Santo e na região de Vitória com relação a parto pretermo e baixo peso ao nascer foram respectivamente: $10,56 \%$ e $12,08 \% ; 9,18 \%$ e $11,17 \% ; 16,54 \%$ e $18,60 \%$. Em números absolutos, parto pretermo e/ou baixo peso ao nascer totalizam 686.997 nascimentos vivos $(22,64 \%$ dos nascimentos no Brasil), o que ainda constitui uma subestimação, porque estes valores não incluem os natimortos, o componente em crescimento da morte perinatal em todo o mundo (Merçon-De-Vargas, 2000; Wiglesworth, 1984).

O baixo peso ao nascer pode ser o resultado de parto pretermo ou de restrição 
de crescimento fetal (Kramer, 2003; López et al., 2002a) e decorrem de numerosas e complexas doenças e condições nosológicas, culturais, sócio-econômicas, geográficas e étnicas bem como das características da assistência pré-natal, parto e nascimento (Naeye e Tafari, 1983). Embora as variações destes fatores expliquem as correspondentes variações geográficas e locais da prevalência de desfecho reprodutivo ruim, esta prevalência é grande e constitui um imenso desafio, sem muitas evidências de melhora recente (Haram et al., 2003; Hoffman e Bakkteig, 1984; Kramer, 2003; Nordenvall e Sandstedt, 1990). Trata-se de situação grave que demanda cuidados intensivos neonatais prolongados e acarretam grandes custos materiais e de serviços para o sistema de saúde, e até emocionais para a família.

As hipóteses levantadas para explicar a associação entre doença periodontal e desfecho reprodutivo ruim são duas: (1) a doença periodontal constitui um foco infeccioso de onde bactérias se disseminam para outros sítios desencadeando novos focos infecciosos e inflamatórios, tais como vaginite, cervicite, endometrite, corioamnionite e vilosite; (2) a infecção e a inflamação periodontais produzem e liberam mediadores inflamatórios que agiriam à distância, no trato genital e nos anexos fetais.

Como outras infecções, a doença periodontal poderia constituir um reservatório crônico de lipopolissacarídeos e outros produtos bacterianos e inflamatórios determinantes diretos ou através da produção de vários mediadores locais (decídua, âmnio, cório, trofoblasto) que atuariam na determinação do parto ou na função do trofoblasto e culminaria com parto pretermo, restrição de crescimento e morte perinatal. Além das infecções, a pré-eclâmpsia também parece associar-se com alterações inflamatórias similares às encontradas na septicemia, como o aumento dos níveis do fator de necrose tumoral-alfa (TNF-a) e de interleucina-6 (Sacks et al., 
1998).

Estas evidências sugerem existir uma relação entre a infecção materna, incluindo doença periodontal, com pré-eclâmpsia e desfecho reprodutivo ruim, embora os mecanismos patogenéticos não tenham sido convincentemente demonstrados, sendo ainda um tema a ser estudado (Moore et al., 2005; Persson et al., 2009).

Os anexos fetais são livres de microrganismos e se eles os atingem, as lesões, as evidências necessárias para estabelecer o nexo entre etiologia e doença, podem ser duas: vilosite e corioamnionite, consideradas marcadores anátomo-patológicos respectivos de possível infecção hematogênica ou transplacentária (Altshuler, 1997; Benirschke et al., 2006; Fox e Sebire, 2007) e de inquestionável infecção amniótica (Blanc, 1961; Naeye e Tafari, 1983).

A vilosite é uma inflamação das vilosidades coriônicas em resposta à presença de microrganismos (Altshuler, 1997; Fox, 1978; Fox e Sebire, 2007) e/ou à resposta imunitária materna a antígenos paternos presentes no feto ou nos anexos fetais, ou resposta imunitária fetal a antígenos maternos (Benirschke et al., 2006; Fox e Sebire, 2007) usualmente denominada vilosite de etiologia desconhecida (Altshuler, 1997; Benirschke et al., 2006; Fox e Sebire, 2007).

Nas vilosites infecciosas, os microrganismos oriundos de qualquer sítio (pele, boca, vias urinárias e respiratórias, trato gastro-intestinal, etc) atingem o espaço interviloso pelo sangue materno, aderem e penetram nas vilosidades, desencadeando respostas inflamatórias materna e fetal, podendo atingir a circulação feto-placentária e infectar o feto (Altshuler, 1997; Benirschke et al., 2006; Fox, 1978; Fox e Sebire, 2007; Kloos e Vogel, 1978). Os microrganismos e as partículas virais 
mais comumente observados são aqueles do complexo $\mathrm{ToRCH}$, que produzem toxoplasmose, rubéola, citomegalovirose e herpes, mas também muitos outros como Parvovírus B19, Trypanosoma cruzi e HIV (Altshuler, 1997; Benirschke et al., 2006; Fox, 1978; Fox e Sebire, 2007; Kloos e Vogel, 1978).

Os dados de prevalência da vilosite variam muito segundo os métodos diagnósticos utilizados. A atribuição de desfecho reprodutivo ruim às vilosites é tema controverso porque, usualmente, não se distinguem as infecciosas das não infecciosas. Nas infecciosas o desfecho reprodutivo ruim é comum e inclui a morte perinatal (Altshuler, 1997; Benirschke et al., 2006; Fox, 1978; Fox e Sebire, 2007; Kloos e Vogel, 1978). Nas vilosites de etiologia desconhecida, parece haver uma maior freqüência de restrição de crescimento fetal, mas raramente de parto pretermo, baixo peso fetal ao nascer ou morte perinatal (Altshuler, 1997; Benirschke et al., 2006; Fox e Sebire, 2007).

A fonte de infecção da cavidade amniótica, é a vagina, de onde geralmente bactérias, fungos, micoplasmas e vírus ascendem através da cérvice uterina, atingindo as membranas extra-placentárias, podendo penetrar a cavidade amniótica e líquido amniótico, infectando assim, o feto diretamente (pele) ou por via transorificial (digestiva ou respiratória) (Blanc, 1959; Benirschke et al., 2006; Fox, 1978; Naeye e Tafari, 1983; Tolockiene et al., 2001). A origem de patógenos vaginais pode ser as microbiotas fecal, oral, cutânea ou peniana, o que é confirmado pela identificação concomitante das mesmas na vagina, membranas fetais, líquido amniótico e feto em casos de infecções perinatais (Sweet e Gibbs, 2002).

O efeito mais temível da infecção amniótica é o parto pretermo, o qual constitui o maior determinante (Morrison, 1990), embora o reconhecimento da 
infecção amniótica como o cerne do problema parto pretermo costuma ser subestimado devido à dificuldade e ao caráter post-factum do diagnóstico de corioamnionite (Merçon-De-Vargas, 1992). Por esta razão, a dimensão epidemiológica do problema perinatal tem sido apresentada como parto pretermo e baixo peso ao nascer, variáveis mais facilmente aferíveis (Kramer, 2003).

Os mecanismos determinantes da parturição são complexos e dependentes da interação de numerosos mediadores, incluindo progesterona, relaxina, óxido nítrico, $\mathrm{CRH}$, hCG, prostaglandinas e citocinas pró-inflamatórias (Haram et al., 2003; Williams et al., 2000a,b). A produção destes mediadores pode ser o eixo hipotálamohipofisário-adrenal-placentário ou em resposta a traumas, hemorragias e agentes infecciosos locais ou sistêmicos (Haram et al., 2003), fenômenos bem conhecidos e operantes nas membranas fetais (Kent et al., 1994; Williamns et al., 2000a,b;). Portanto, a infecção e a inflamação podem representar um fator precipitador ou amplificador da parturição fisiológica que, desencadeada, antecipa e culmina em parto pretermo (Haram et al., 2003; Naeye e Tafari, 1983; Williamns et al., 2000a,b).

Embora a identificação de bactérias no líquido amniótico seja possível há décadas (Fox e Langley, 1971; Fox, 1978; Hill, 1993) somente com as novas técnicas de biologia molecular, tem-se reduzido a incômoda situação representada pela dificuldade de comprová-la em todos os casos (Fox e Sebire, 2007; Han et al., 2009).

Acredita-se que parturientes de baixo nível sócio-econômico sejam as mais vulneráveis a desenvolver doença periodontal, infecção amniótica e baixa situação de saúde perinatal.

Assim, para evidenciar uma das fontes de microrganismos (a boca), as vias 
de contaminação da cavidade amniótica (hematogênica ou a vagina), sítios da infecção (parênquima da placenta ou âmnio), infecção amniótica (presença de BPPG no âmnio) ou parênquima da placenta (BPPG no parênquima) e lesões (corioamnionite ou vilosite), e finalmente, para analisar a provável relação entre estes e o desfecho reprodutivo ruim, foi delineado o presente estudo. 


\section{OBJETIVOS}

\subsection{Geral}

Pretendeu-se neste estudo transversal avaliar a associação entre doença periodontal e bactérias periodontopatogênicas (BPPG) no âmnio com corioamnionite (CAM) e quatro tipos de desfecho reprodutivo ruim/DRR (Parto pretermo/PPT, Rotura precoce das membranas fetais/PROM e rotura precoce e pretermo das membranas fetais/PPROM, Baixo peso ao nascer/BPN e Morte perinatal/MPN).

\subsection{Específicos}

2.2.1 Determinar a prevalência da doença periodontal em parturientes;

2.2.2 Determinar a prevalência de quatro periodontopatógenos (Porphyromonas gingivalis, Aggregatibacter actinomycetemcomitans, Fusobacterium nucleatum e Tannerella forsythia) nas bolsas periodontais, vagina, âmnio e parênquima da placenta;

2.2.3 Verificar a provável relação entre a presença desses periodontopatógenos no biofilme subgengival, vagina, âmnio, parênquima da placenta e desfecho reprodutivo ruim. 


\section{REVISÃO DA LITERATURA}

\subsection{A Doença periodontal}

A doença periodontal é uma enfermidade de natureza infecciosa, e está associada primeiramente à colonização das superfícies dos dentes por bactérias anaeróbias Gram-negativas que induzem uma resposta inflamatória a qual pode acarretar a destruição dos tecidos periodontais (Offenbacher, 1996; Page, 1998).

O biofilme bacteriano é o principal responsável por esta perda de tecidos uma vez que o seu acúmulo na superfície dental atua como um agente irritativo e desencadeia a resposta inflamatória/imunológica no tecido gengival adjacente (Offenbacher, 1996; Page, 1998). A falta de higiene bucal favorece a progressão do biofilme dental sobre os tecidos periodontais. Para testar essa hipótese, Löe et al. (1986) avaliaram a progressão da doença periodontal por um período de 15 anos em plantadores de chá do Sri Lanka, observando-se que a gengivite era uma doença generalizada, e $8 \%$ deles desenvolveram rápida perda de inserção, e 81\% progressão moderada. Observaram ainda que alguns indivíduos possuíram diferentes susceptibilidades à infecção.

A gengivite é comum e se manifesta clinicamente com o sangramento dos tecidos gengivais, sem evidências clínicas de perda de inserção do dente ao osso alveolar ou de perda óssea. Por sua vez, a periodontite ou doença periodontal destrutiva ocorre quando a resposta inflamatória induzida pelo biofilme nos tecidos resulta na perda de inserção das fibras colágenas do dente ao osso, na perda do osso alveolar e na eventual perda do dente. Portanto, a doença periodontal é a descrição geral dada à resposta inflamatória da gengiva e do tecido conjuntivo subjacente ao acúmulo de bactérias sobre o dente. Esses acúmulos bacterianos são altamente complexos e bem organizados em comunidades microbianas conhecidas como biofilme dentário (Löesche,1993).

Essa biomassa bacteriana distribui-se na cavidade bucal com cerca de 500 espécies, e algumas isoladas ou associadas na forma de biofilme são responsáveis pela destruição do tecido periodontal (Socransky e Haffajee, 1997). Recentemente, 
mais de 700 espécies bacterianas da cavidade bucal têm sido identificadas por meio de métodos moleculares. Por sua vez, acima de 400 espécies têm sido identificadas de bolsas periodontais, enquanto as 300 espécies remanescentes são isoladas de outros sítios bucais, tais como, dorso de língua, membranas mucosas, lesões de cáries e infecções endodônticas (Paster et al., 2006). Por outro lado, cerca de 35\% destas espécies bacterianas bucais não são cultivadas in vitro (Paster e Dewhirst, 2009).

No último quarto do século, notável progresso foi alcançado sobre a compreensão da natureza da doença periodontal. Deste modo, o impacto da infecção bucal sobre a saúde sistêmica possibilitou definir um novo ramo da periodontologia chamada de Medicina Periodontal. Em essência, dentistas e periodontistas são treinados para salvar dentes, mas regras clínicas para manipular a infecção bucal com finalidade de proteger a saúde sistêmica representam uma lacuna no conhecimento (Williams e Offenbacher, 2000).

\subsection{A Inflamação na doença periodontal}

$\mathrm{Na}$ patogênese da doença periodontal os mediadores químicos mais amplamente investigados têm sido a interleucina-1 (IL-1), o fator de necrose tumorala (FNT-a) e as prostaglandinas (PG) (Lindemann et al., 1988; Offenbacher, 1993; Page, 1991; Stashenko et al., 1987). Essas moléculas endógenas são responsáveis pela amplificação e perpetuação da resposta inflamatória, representando os principais fatores associados à destruição periodontal. A IL-1 é produzida predominantemente por macrófagos ativados por substâncias microbianas, especialmente por lipopolissacarídeos de bactérias Gram-negativas, mas, também, por complexos imunes e outras citocinas, linfócitos, plaquetas, fibroblastos, queratinócitos, e células endoteliais. Já, a prostaglandina E2 (PGE2), um produto do metabolismo do ácido araquidônico e produzida pelo hospedeiro é responsável pela destruição tecidual na doença periodontal, induz vasodilatação, aumento da permeabilidade vascular, promovendo edema e eritema. Também, atua na infiltração de células inflamatórias, e induzem à síntese de metaloproteinases, que degradam a matriz extracelular tecidual levando a destruição do tecido conjuntivo. 
O FNT- $\alpha$ atua concomitantemente com a IL-1, sendo produzido por macrófagos após sua ativação por LPS, atuando em leucócitos, células endoteliais e células do tecido conjuntivo, podendo estimular a proliferação de precursores de osteoclastos induzindo a reabsorção óssea (Offenbacher, 1996a; Page, 1991).

Embora o papel dos mediadores inflamatórios seja importante no trabalho de parto, admite-se que haja mecanismos biológicos associando a severidade da doença periodontal com o parto pretermo e o baixo peso fetal, porém sem confirmar uma relação linear causal. Postula-se que as gestantes acometidas por essas duas desordens tenham uma predisposição genética para uma resposta hiperinflamatória na presença de um desafio bacteriano. Deste modo, a infecção periodontal crônica age como um reservatório de produtos bacterianos ou de mediadores inflamatórios, ou ainda, de ambos, acarretando parto pretermo com baixo peso ao nascer (McGaw, 2002).

\subsection{Relações entre doença periodontal, periodontopatógenos e desfechos reprodutivos ruins.}

Muitos estudos têm sido direcionados à mera identificação de patógenos periodontais no líquido amniótico, sem a inclusão do exame anátomo-patológico da placenta. O desafio atual para determinar a importância da doença periodontal e das BPPG no desfecho reprodutivo ruim demanda que se demonstrem os agentes etiológicos na bolsa periodontal ou sulco gengival, no trato vaginal, anexos fetais e feto.

Durante a gravidez, o hormônio sexual se desequilibra e aumenta, afetando muitos órgãos. Foram reconhecidos na gengiva receptores de estrogênio e de progesterona; isto explica, entre outros fatores, a maior resposta gengival à placa (O’Neil, 1979; Vittek et al., 1979). Há também uma maior permeabilidade capilar gengival e, logo, um maior fluxo de líquido gengival (Löe, 1965). Além disso, a própria composição bacteriana está modificada pelos níveis aumentados de estradiol e progesterona, que favorecem o aumento da taxa de proporção de bactérias anaeróbias, e, em particular, Prevotella intermedia no segundo trimestre da gestação. No pós-parto, existe uma taxa menor na proporção de anaeróbios e 
aeróbios, porém F. nucleatum mantém-se como o anaeróbio mais prevalente (Kornman e Löesche, 1980).

O microrganismo anaeróbio Gram-negativo, $F$. nucleatum, tem sido freqüentemente isolado do líquido amniótico de gestantes com membranas fetais intactas e também do trato genital inferior. Esses resultados forneceram evidências de que as espécies e subespécies de fusobactérias isoladas desses sítios corporais estabeleceram a cavidade vaginal como uma fonte endógena primária.

Além disso, tem sido sugerido que a disseminação do $F$. nucleatum para o líquido amniótico origina-se na cavidade bucal da gestante (via hematogênica), ou da microbiota bucal do parceiro via contato orogenital (via ascendente) ou, ainda um aumento na colonização desse microrganismo no trato genital (via ascendente) durante a gestação (Bearfield et al., 2002; Hill, 1993). Além do F. nucleatum, outros microrganismos, tais como, Ureaplasma urealyticum, Mycoplasma hominis e Bacteroides urealyticus tem sido frequentemente detectados no liquido amniótico (Chaim e Mazor, 1992; Han et al., 2009; Hill, 1998; Romero et al., 1991; Watts et al., 1992). Estes microrganismos são considerados patógenos indígenas oportunistas do trato genital inferior da mulher e geralmente estão associados com vaginose bacteriana, considerada fator de risco para o nascimento de prematuros (Chaim et al., 1997; Hill, 1998; Yoon et al., 2000). Por sua vez, Madianos et al. (2001) demonstraram que a disseminação de outras bactérias bucais para a unidade fetoplacentária, tais como, Campylobacter rectus e $P$. intermedia induziu uma resposta imune no feto com aumento significante no nível de IgM nas gestantes com partos pretermos.

Vários fatores de risco foram avaliados em 124 mães com doença periodontal severa indicando que até $18 \%$ das puérperas com recém-nascidos de baixo peso poderiam ser devidos a infecções periodontais e as razões atribuíveis para esses nascimentos prematuros foram: 1) semelhantemente às infecções genito-urinárias, a periodontite pode ser causada por bactérias Gram-negativas anaeróbias que colonizam a área subgengival do paciente liberando lipopolissacarídeos de superfície (LPS); e, 2) o sistema imune da paciente reage a esses antígenos de uma forma que os níveis sanguíneos de citocinas inflamatórias, como PGE2, IL-1 e TNFa aumentam significativamente (Offenbacher et al., 1996a,b). Semelhantemente, Jeffcoat et al. (2001a) verificaram um aumento de 5 a 7 vezes maior nas gestantes 
com periodontite severa e generalizada que tiveram parto pretermo entre a $32^{\mathrm{a}}$ e $35^{\mathrm{a}}$ semana de idade gestacional. Quanto à morte perinatal, Shub et al. (2009) demonstraram associação entre doença periodontal materna e mortalidade perinatal nas gestantes com parto pretermo.

Outros estudos avaliaram a influência da doença periodontal durante a gravidez sobre o peso das crianças ao nascer (BPN) encontrando forte associação entre a extensão e severidade da infecção periodontal e BPN (Alves e Ribeiro, 2006; Bobetsis et al., 2006; Bosnjak et al., 2006; Brunetti, 2002; Clothier et al., 2007; Glesse et al., 2004; Gontijo et al., 2006; Guimarães et al., 2010; Khader e Ta'Ani, 2005; Khader et al., 2009; Jarjoura et al., 2005; Lopez et al., 2005; Louro et al., 2001; Lunardelli e Peres, 2005; Moliterno et al., 2005; Offenbacher et al., 2006; Radnai et al., 2004; Rakoto-Alson et al., 2010; Rajapakse et al., 2005; Santos-Pereira et al., 2007; Sharma et al., 2007; Toygar et al., 2007; Úrban et al., 2006; Vergnes e Sixou, 2007; Vettore et al., 2006; Xiong et al., 2006). Entretanto, outras pesquisas têm apontado uma ausência dessa associação (Agueda et al., 2008; Bassani et al., 2007; Cruz et al., 2009; Farrell et al., 2006; Gomes-Filho et al., 2006; Lohsoonthorn et al., 2009; Meurman et al., 2006; Moore et al., 2004; Moore et al., 2005).

Quanto aos parâmetros clínicos periodontais, Offenbacher et al. (2001) mostraram que a progressão da periodontite materna favorece risco obstétrico para parto pretermo e baixo peso ao nascer em gestantes com idade gestacional antes da 26 semana, e com menos de 37 semanas gestacionais (Offenbacher et al., 2006). Contudo, Marin et al. (2005) demonstraram associação significante entre sangramento à sondagem em gestantes acima de 25 anos de idade com neonatos com baixo peso. A profundidade de bolsa também se mostrou estatisticamente significante entre baixo peso ao nascer, especialmente em sítios $>3,0 \mathrm{~mm}$ (Moreu et al., 2005), porém no estudo de Moss et al. (2005) o número total de sítios periodontais que experimentaram progressão não se associou com esses fatores de risco, mas o sangramento gengival à sondagem e a presença de quatro ou mais sítios com bolsas $\geq 4,0 \mathrm{~mm}$ foram os dois melhores preditores. Também, Noack et al. (2005) não encontraram diferenças significante nos parâmetros de severidade da periodontite ( $\mathrm{PB}>2,0 \mathrm{~mm}$ após parto) relacionados aos desfechos. 
Com respeito ao efeito da terapêutica periodontal para reduzir risco de parto pretermo, os dados até então não mostraram evidências suficientes do efeito significante da terapia periodontal na redução desses desfechos (Jeffcoat et al., 2001b; Jeffcoat et al., 2003; Gazolla et al., 2007; Macones et al., 2009; Michalowicz et al., 2006; Michalowicz et al., 2009; Mitchell-Lewis et al., 2001; Newnham et al., 2009; Offenbacher et al., 2009; Scannapieco et al., 2002; Wimmer e Pihlstrom, 2008). Diferentemente dos estudos acima mencionados, a terapia periodontal reduziu significantemente a taxa de partos pretermos e de baixo peso ao nascer (PTBPN) em gestantes com doença periodontal (López; et al., 2002a,b; 2005; Tarannum e Faizuddin, 2007; Polyzos et al., 2009).

Os fatores de risco, situação sócio-econômica, idade, etnia com associação na raça negra (Bosnjak et al., 2006; Henriques, 2003; Lieff et al., 2004) e também na raça branca (Pitiphat et al., 2008), parto pretermo prévio (Mokeem et al.,2004), nível de escolaridade (Cruz et al., 2005), e tabagismo (Bergstrom, 1990, 1998, 2004; Grossi et al., 1995; Holbrook et al., 2004; Jeffcoat et al., 2001a, 2001b; Swenson. 1979), também têm sido relacionados com os marcadores clínicos da doença periodontal e desfechos reprodutivos ruins (Kierse, 1989; Shah e Bracken, 2000; Shiono et al., 1986) nas gestantes. Moore et al. (2001) mostraram uma maior proporção de bolsas periodontais, placa dental, e perda de inserção associados positivamente com esses fatores de risco conhecidos, diferentemente de Davenport et al. (2002) que não encontraram nenhuma relação significante.

Sabe-se, também, que partos pretermos são as principais causas de morbidade e mortalidade neonatal, e que representam um capítulo especial muito importante em saúde pública. Cerca de $30 \%$ dos partos pretermos são devido às condições médicas da mãe ou do feto, entre os quais, a pré-eclampsia tem um papel principal. Em geral, essa morbidade materna tem sido relatada associação com periodontite moderada ou severa, (Contreras et al., 2006; Kunnen et al., 2007; Riché et al.,2002) localizada ou generalizada entre as gestantes com parto pretermo (Nabet et al., 2010).

A vaginose bacteriana na gestação além de aumentar o risco para desfechos reprodutivos ruins tem sido associada significantemente com infecção periodontal 
(Marakoglu et al., 2008; Oittinen et al., 2005; Ovalle et al., 2009). Microrganismos tais como F. nucleatum, Ureaplasma urealyticum, Mycoplasma hominis e $B$. urealyticus (Chaim e Mazor, 1992; Hill, 1998; Romero et al., 1991; Watts et al., 1992) são considerados patógenos indígenas oportunistas do trato genital inferior da mulher e freqüentemente estão associados com vaginose bacteriana (Chaim et al., 1997; Hill, 1998; Yoon et al., 2000). Persson et al. (2009) investigando gestantes com gengivite e com vaginose bacteriana identificaram os periodontopatógenos $A$. actinomycetemcomitans (sorotipos a e b), Capnocytophaga gingivalis, C. ochracea, $C$. rectus, $E$. corrodens, $F$. nucleatum, $P$. gingivalis, $T$. forsythia, $T$. socranskii, alem de $P$. intermedia e $P$. nigrescens nas mulheres com gengivite, mas independente do diagnóstico de VB, igualmente, os mesmos patógenos periodontais obtidos de amostras vaginais relatado por Srinivasan et al. (2009).

As pesquisas mostram que as infecções intra-uterinas são altamente prevalentes entre mulheres que geraram neonatos prematuramente. Existem quatro possíveis mecanismos para disseminação de microrganismos até o útero, um ambiente considerado estéril: 1) os microrganismos que colonizam a vagina e a cérvice ascendem para o útero; 2) os microrganismos são transmitidos hematogicamente; 3) os microrganismos da cavidade peritoneal espalham retrogadamente através das trompas de falópio; e 4) os microrganismos são inoculados acidentalmente dentro do útero durante procedimentos invasivos, tais como amniocentese e amostragem da vilosidade coriônica. Mas, a infecção ascendente é considerada entre estes como a via de infecção mais comum. Por outro lado, a disseminação de microrganismos pelo sangue de outras partes do corpo humano para o útero é uma via secundária (Chaim e Mazor, 1992; Gonçalves et al., 2002; Romero et al., 1991).

A associação entre marcadores inflamatórios do trato genital superior na época do parto e doença periodontal apresentaram taxas muito semelhantes, porém sem significância. Goepfert et al. (2004) isolaram apenas os periodontopatógenos Peptostreptococcus micros, Streptococcus constellatus e Eubacterium sp. em cultura de placenta em cinco puérperas com parto pretermo espontâneo e em três com parto a termo. Mas nenhuma associação entre doença periodontal foi encontrada entre esses marcadores genitais e parto pretermo, fato esse também 
relatado por Holbrook et al. (2004), ou seja, nenhuma associação foi encontrada entre a microbiota oral e vaginal em gestantes com partos pretermos.

Dortbudak et al. (2005) ao analisarem se a periodontite era fator preditor para desfecho reprodutivo ruim, especialmente nascimento de prematuros, as amostras do líquido amniótico das gestantes não mostraram evidências de crescimento bacteriano, igualmente, Han et al. (2006) em 34 gestantes. No entanto, León et al. (2007) e Ovalle et al. (2009) investigando gestantes com doença periodontal e com ruptura prematura das membranas fetais e com trabalho de parto pretermo (PPROM) detectaram $P$. gingivalis nas amostras de líquido amniótico. Entre as bactérias bucais, F. nucleatum foi predominante nas amostras do líquido amniótico, ou seja, das sete gestantes, seis tinham membranas fetais intactas e apenas uma com PPROM (Han et al. 2009). Outro periodontopatógeno, Eikenella corrodens um bastonete Gram-negativo foi isolado por cultivo do líquido amniótico em gestante primigrávida de 17 anos de idade (Jadhav et al., 2009).

Estudos relacionando patógenos periodontais no biofilme subgengival como indicadores de risco (ou preditores) e parâmetros periodontais para parto pretermo e baixo peso fetal têm sido invariavelmente discutidos na literatura. Hasegawa et al. (2003) não observaram diferenças significantes entre gestantes com trabalho de parto pretermo (TPPT), parto a termo (TPPT-PT), e trabalho de parto pretermo e parto pretermo (TPPT-PPT) na porcentagem da bactéria periodontopatogênica $T$. forsythia. Por outro lado, A. actinomycetemcomitans, $P$. gingivalis e Prevotella spp. foram predominantes no biofilme subgengival de puérperas com parto pretermo (Holbrook et al., 2004). Por sua vez, Buduneli et al. (2005) verificaram que a ocorrência de $P$. intermedia, $F$. nucleatum, $P$. micros, $C$. rectus, $E$. corrodens, Selenomas noxia e $S$. intermedius foi maior nas gestantes com neonatos de baixo peso fetal comparado ao controle, mas as diferenças não foram significativas estatisticamente. Por outro lado, os microrganismos $P$. micros e $C$. rectus foram responsáveis pelo aumento significativo para o risco de baixo peso fetal, enquanto as espécies $P$. nigrescens e $A$. actinomycetemcomitans reduziram este risco. Diferenças significantes também foram relatadas por Skuldbol et al. (2006) com relação aos microrganismos $T$. forsythia, Treponema denticola, Peptostreptococcus micros, Streptococcus intermedius, Streptococcus oralis, Streptococcus sanguis e 
Capnocytophaga ochracea nas gestantes com parto pretermo e periodontite, mas sem nenhuma associação. A bactéria Bergeyella sp. foi detectada por Han et al. (2006) em apenas uma gestante (placa subgengival, mas não no trato vaginal). Quanto às gestantes com rotura precoce e prematura das membranas fetais e com trabalho de parto pretermo (PPROM), P.gingivalis foi detectado no biofilme subgengival. Em relação às outras BPPGs, nenhuma espécie foi identificada pelos exames microbiológicos (Cultura ou PCR) (León et al., 2007). Utilizando a técnica de checkerboard DNA-DNA, Vettore et al. (2008) identificaram apenas S. mitis e T. socranskii e mostraram diferenças significantes nas gestantes com parto pretermo e baixo peso fetal (PTBPN), porém as freqüências de bolsas periodontais $\geq 4,0 \mathrm{~mm} e$ do nível clínico de inserção $\geq 3,0 \mathrm{~mm}$ não foram associadas com parto pretermo e de baixo peso fetal. No entanto, as contagens de F. nucleatum, $P$. gingivalis, $S$. mitis $e$ T. forsythia apresentaram significância com o índice de sangramento a sondagem na $12^{\text {a }}$ semana de gestação, além de uma relação de significância com os patógenos $A$. naeslundii, $A$. odontolyticus e Prevotella nigrescens na $28^{\text {a }}$ semana gestacional. Contudo, os níveis subgengivais de $A$. actinomycetemcomitans, $P$. gingivalis, $T$. forsythia e $T$. denticola não se alteraram durante a gestação. Já na $12^{a}$ de gravidez, níveis elevados de $P$. gingivalis e $T$. forsythia estavam associados com sangramento gengival à sondagem (Adriaens et al., 2009).

As amostras de biofilme subgengival BANA-infectadas de gestantes no terceiro trimestre, bem como, ruptura prematura pretermo das membranas fetais foram preditores positivos significantes para partos pretermos (Chan et al., 2010). Por outro lado, espécies e subespécies de F.nucleatum foram identificadas por Han et al. (2010) nas amostras de biofilme subgengival de uma puérpera asiática, primigrávida de 35 anos de idade com gengivite e com feto natimorto. Entre as BPPG, $P$. gingivalis, mostrou uma diferença significante com desfecho reprodutivo ruim, mas nenhuma condição clínica periodontal não mostrou associação significante com parto pretermo (Ryu et al., 2010).

Outra vez mais as evidências apontam para um aumento da associação entre doença periodontal e desfechos reprodutivos ruins. Embora a infecção periodontal seja considerada um fator de risco para parto pretermo, a localização da bactéria bucal ou de seus antígenos nos tecidos placentários infectados por corioamnionite não tem sido demonstrada. Assim, espécimes de tecido placentário foram obtidos da 
parte maternal e da parte fetal de gestantes com pré-eclampsia e com membranas fetais íntegras para identificar o DNA bacteriano por meio da técnica da reação em cadeia da polimerase em tempo real. Entre as BPPG, mereceram destaques, $T$. denticola (predominante), P. gingivalis T. forsythia, P. intermedia, F. nucleatum, A. actinomycetemcomitans, respectivamente por ordem do número de células (Barak et al. 2007). Por meio da imunocitoquímica, Katz et al. (2009) identificaram antígenos de P.gingivalis na placenta (decídua), nas vilosidades coriônicas (trofoblasto e endotélio) e no epitélio amniótico em um grupo de gestantes com parto pretermo, parto a termo e com trabalho de parto pretermo complicado por corioamnionite. Hasegawa-Nakamura et al. (2011) isolaram $P$. gingivalis de tecidos coriônicos placentários de 23 gestantes de alto risco e no biofilme subgengival de 11 gestantes com doença periodontal. No entanto, não houve diferenças significantes nas médias das idades gestacionais e do peso do recém-nascido entre as gestantes $P$.gingivalis positivo para tecido coriônico.

\subsection{A Placenta}

\subsubsection{A Inflamação na placenta}

A inflamação clínica tem sido classicamente definida por calor, dor, rubor, edema e diminuição da função, e isto reflete os efeitos dos mediadores inflamatórios nos tecidos e nos vasos sanguíneos locais. Em contraste, a inflamação histológica, que é o padrão-ouro para o diagnóstico, é definida pela infiltração do tecido por neutrófilos, macrófagos e linfócitos. O tipo de infiltrado celular é utilizado para classificar a inflamação como aguda ou crônica (Romero et al., 2006, 2007b). Os três principais objetivos da inflamação são: a entrega de células e moléculas para suprimir a infecção; a formação de uma barreira física contra a disseminação da infecção; e a promoção de reparos ao tecido. A inflamação é parte da resposta imune primária, que atua imediatamente, é não-específica e não tem memória, entretanto, também pode levar à doença quando exagerada (Romero et al., 2006).

A inflamação tem sido implicada nos mecanismos responsáveis pela parturição a termo e pretermo, assim como na injúria fetal. Infecção e/ou inflamação é o único processo patológico para o qual uma ligação causal firme com o nascimento prétermo foi estabelecida e uma patofisiologia molecular foi definida (Romero et al., 
2006). Componentes do sistema imune, como os complexos de histocompatibilidade têm sido implicados no processo de abortamento espontâneo, já que uma resposta inflamatória exagerada, sistêmica ou localizada, é um mecanismo de doença no abortamento espontâneo, parto prematuro, PPROM, pré-eclâmpsia e outras "grandes síndromes obstétricas" (Romero et al., 2007b). A respeito disso, há consideráveis evidências de que citocinas pró-inflamatórias são importantes na patogênese da corioamnionite humana. Níveis de diversas interleucinas e proteínas quimioatraentes de monócitos estão significativamente elevados em casos de trabalho de parto prematuro nos quais há evidências histológicas de corioamnionite (Goldman e Schmalsteig, 2008).

A ruptura das membranas fetais ao termo é uma parte normal do processo de parturição que ocorre após o início das contrações uterinas. Entretanto, o nascimento prematuro é a principal causa de mortalidade e morbidade neonatal no mundo e exibe uma relação inversamente proporcional à idade gestacional, tanto que os neonatos prematuros precoces respondem pela vasta maioria dos óbitos. Conseqüentemente, a necessidade de esclarecimentos sobre os fatores que contribuem para o parto prematuro precoce é particularmente urgente (Digiulio et al., 2008; Mass et al., 1999; Menon e Fortunato, 2007; Romero et al., 2006).

Uma resposta inflamatória do hospedeiro tem sido considerada como parte da patogênese do parto prematuro, sendo infecção e inflamação intra-uterinas importantes mecanismos de doença. As evidências que dão suporte a esta conclusão incluem o fato de que a infecção intra-uterina ou a administração sistêmica de produtos microbianos em animal pode resultar em trabalho de parto prematuro e conseqüente parto; infecções maternas extra-uterinas, como a pielonefrite, por exemplo, estarem associadas com parturição prematura; infecções intra-uterinas subclínica estarem associadas trabalho de parto e parto prematuro; pacientes com infecção intra-amniótica ou inflamação intra-uterina no trimestre médio de gestação estar em risco para subseqüente parto prematuro; tratamento antibiótico das infecções intra-uterinas ascendentes poderem prevenir a prematuridade em modelos experimentais de corioamnionite; e tratamento de bacteriúria assintomática prevenir a prematuridade (Romero et al., 2006, 2007a). 


\subsubsection{A Microbiota vaginal e sua relação com o tipo de parto e com a corioamnionite}

Em estudo prospectivo, os microrganismos Gardnerela vaginalis e Bacteroides spp. foram os mais significativos e causadores da vaginose bacteriana quando se comparou a microbiota vaginal de 428 mulheres em trabalho de parto prematuro com à de 568 mulheres em trabalho de parto no tempo normal (Mcdonald et al.,1994).

Em outro estudo multicêntrico realizado em 10397 gestantes, a vaginose bacteriana estava associada à prematuridade e ao baixo peso do recém-nascido, independentemente de outros fatores de risco conhecidos. A vaginose foi detectada em $16 \%$ das pacientes examinadas (Hillier et al.,1995).

Diante disso, tem sido ressaltada a existência de uma relação positiva entre a vaginose bacteriana e o parto prematuro, alertando para a necessidade do tratamento dessa doença tanto na presença de vaginose sintomática quanto na presença de vaginose sem sintomas (Chaim et al.,1997).

Por sua vez, em um estudo tipo caso-controle, a vaginose bacteriana durante a gestação esteve claramente associada com o aumento do risco de prematuridade e recém-nascido de baixo peso. O estudo foi feito com 217 mulheres com idade gestacional entre 28 e 32 semanas, 35 delas com vaginose bacteriana (grupo caso) e 182 sem essa enfermidade (grupo controle). Os autores verificaram que as incidências de trabalho de parto pretermo, de ruptura prematura de membranas e de baixo peso ao nascimento foram maiores no grupo caso do que no grupo controle, e que as médias de idade gestacional e do peso ao nascer foram menores nos recémnascidos das mulheres do grupo caso (Simões et al.,1998).

Além das evidências crescentes acerca da relação entre o trabalho de parto prematuro e o nascimento pré-termo com a infecção do líquido amniótico e/ou do corioâmnio, observações têm sido descritas relacionando este tipo de infecção com as alterações na microbiota vaginal da gestante. Esfregaços cervicais de mulheres com corioamnionite aguda revelaram-se significativamente maior predominância de cocobacilos, consistente com um desvio na microbiota vaginal, analisada pelos 
exames de citologia cérvico-vaginal corados pelo método de Papanicolaou do que as mulheres sem corioamnionite (Mass et al., 1999).

\subsubsection{A Invasão microbiana da cavidade amniótica}

Os eventos adversos associados à invasão microbiana podem ser devido aos produtos bacterianos ou à proliferação de microrganismos intactos. A maioria dos efeitos dos microrganismos é mediada por produtos liberados durante a morte da bactéria. Conseqüentemente, bactérias não-viáveis podem exercer efeitos deletérios se seus produtos forem reconhecidos e promoverem uma resposta inflamatória. De fato, neste estudo, concentrações de endotoxina bacteriana no líquido amniótico foram encontradas e em concentrações muito maiores nas mulheres que apresentaram trabalho de parto com PPROM do que naquelas que apresentaram PPROM, mas sem o trabalho de parto (Romero et al., 2006). Os microrganismos podem ter acesso à cavidade amniótica e ao feto usando qualquer uma das seguintes rotas: ascensão a partir da vagina e/ou da cérvice uterina, que é a forma mais comum; disseminação hematogênica através da placenta; ligadura retrógrada a partir da cavidade peritoneal; e introdução acidental durante procedimentos invasivo (Romero et al., 2006)

A cavidade amniótica da mulher é considerada livre de bactérias desde que as membranas fetais estejam intactas e não esteja em trabalho de parto. A invasão microbiana do líquido amniótico foi evidenciada em aproximadamente $19 \%$ das pacientes em trabalho de parto a termo espontâneo com membranas fetais intactas e em 34\% das pacientes com PROM ao termo. Evidências experimentais recentes indicam que as contrações uterinas exercem um efeito semelhante à sucção, de forma que o fluido vaginal pode ascender para a cavidade uterina com as contrações. Assim, é possível que as contrações uterinas durante o trabalho de parto aumentem o risco de invasão microbiana do líquido amniótico (Seong et al., 2008).

Inflamação intra-amniótica é encontrada em aproximadamente 40\% dos pacientes com PPROM e é um fator de risco para parto prematuro e gestação e desfecho neonatal adversos, com a comprovação ou não da infecção microbiana do 
líquido amniótico através de técnicas de cultura (Lee et al., 2007; Park et al., 2009 Seong et al., 2008). O ataque microbiano ao feto tem lugar em aproximadamente $10 \%$ das gestações com infecção intra-aminótica, e o feto humano é capaz de deflagrar uma resposta inflamatória (celular e humoral) no trimestre médio da gestação (Romero et al., 2007a).

Infecção intra-uterina ascendente tem sido descrita em estágios, sendo a infecção fetal a fase mais avançada. Quando a infecção está limitada ao espaço amniocoriônico ou à decídua (inflamação localizada confinada ao coriodecídua), o processo inflamatório é detectado nas membranas e é de origem materna. O próximo estágio é a invasão microbiana da cavidade amniótica através do âmnio (inflamação do âmnio ou da placa coriônica, sem funisite) e o processo inflamatório intra-amniótico parece ser de origem fetal mais do que materna. O estágio final, no qual há invasão do feto pelos microrganismos, freqüentemente promove uma resposta inflamatória fetal (corioamnionite histológica com funisite), porém estas lesões também podem ocorrer em resposta ao estímulo quimiotático presente na cavidade amniótica, sem invasão microbiana do feto (Park et al., 2009).

Alternativamente, microrganismos da vagina e da cérvice uterina podem transpor as membranas adjacentes à cérvice e colonizar o líquido amniótico sem o envolvimento da decídua, membrana corioamniótica e âmnio, o que parece ocorrer na PPROM e na incompetência cervical. É importante determinar a relação entre a bactéria encontrada na membrana corioamniótica, a resposta inflamatória fetal e/ou intra-amniótica e a inflamação dos diferentes constituintes da placenta. Isto irá aperfeiçoar a compreensão da via de infecção assim como da natureza da resposta inflamatória nos compartimentos fetal e materno da placenta (Park et al., 2009). 


\section{MATERIAIS E MÉTODOS}

\subsection{Seleção de paciente}

Inicialmente, foram selecionadas 119 puérperas, das quais 116 apresentaram placenta única. Destas, somente 93 atenderam os critérios de inclusão, e compreenderam partos do II e do III trimestres da gestação. Neste estudo de corte transversal as puérperas foram assistidas na Maternidade do Hospital Universitário público terciário Cassiano Antônio de Moraes (HUCAM), localizado na Av. Marechal Campos, 1468, Bairro Santos Dumont, Vitória-ES, no período de 6 de maio a 10 de agosto de 2009 .

\subsection{Critérios de inclusão e exclusão}

Os critérios de inclusão foram: (1) idade gestacional (IG) $\geq 22$ semanas pósmenstruais completas (spm) empregando-se a melhor estimativa obstétrica em cada caso (ultrassonografia disponível em 92\% dos casos); (2) ter pelo menos 15 dentes na cavidade bucal; 3) consentimento livre e esclarecido assinado pela parturiente para participar deste estudo. Foram excluídas as puérperas em que não foi possível realizar os exames clínicos periodontais.

\subsection{Processamento histopatológico}

$\mathrm{Na}$ maternidade, a placenta e os anexos fetais foram acondicionados em sacos plásticos esterilizados, sem formaldeído, e identificados com o nome da paciente e a data da terminação. Este material foi conservado a $4{ }^{\circ} \mathrm{C}$ até $\mathrm{O}$ processamento laboratorial no Serviço de Patologia do HUCAM de acordo com critérios estabelecidos, e sob responsabilidade do Prof. Dr. Paulo Roberto Merçon de Vargas.

\subsection{Procedimentos clínicos}

\subsubsection{Informações médicas-obstétricas}

Os dados obstétricos e perinatais empregados neste estudo foram obtidos dos prontuários institucionais e em anamnese, empregando-se protocolo de estudo concomitante sobre desfecho obstétrico atribuível à infecção amniótica. 


\subsubsection{Exame periodontal}

O exame clínico periodontal foi realizado por especialista em periodontia treinado até 72 horas pós-parto (Offenbacher et al.,1996), conforme detalhamento no Fluxograma 2. As mensurações clínicas foram realizadas em seis sítios por dente (mésio-vestibular, vestibular, disto-vestibular, mésio-lingual, lingual e distolingual), em todos os dentes (exceto os terceiros molares), utilizando-se sonda periodontal milimetrada Carolina do Norte (PCPUNC-BR 15, Hufriedy do Brasil, Rio de Janeiro, RJ, Brasil). Foram analisados os seguintes parâmetros periodontais: (1) Sondagem do Nível Clínico de Inserção ( $\mathrm{NCl}$ ), aferindo-se a distância, em milímetros, entre a junção cemento-esmalte e a porção mais apical da bolsa/sulco periodontal; (2) Profundidade Clínica de Sondagem (PS), aferindo-se a distância, em milímetros, entre a margem gengival livre e a porção mais apical sondável da bolsa/sulco periodontal; (3) Índice de Placa Visível (IPV): presença (escore 1) ou ausência (escore 0) de placa supragengival visível (Ainamo e Bay, 1975); (4) Índice de Sangramento Gengival Marginal (ISG): presença (escore 1) ou ausência (escore 0) de sangramento gengival marginal, após percorrer levemente a sonda ao longo da bolsa periodontal/sulco (Ainamo e Bay, 1975); (5) Sangramento à Sondagem (SS): presença (escore 1) ou ausência (escore 0) de sangramento após 20 segundos da sondagem; (6) Supuração (SUP): presença (escore 1) ou ausência (escore 0 ) de supuração espontânea ou após 20 segundos da sondagem.

A presença de periodontite foi diagnosticada se: $\mathrm{PS} \geq 4,0 \mathrm{~mm}$ e $\mathrm{NCl} \geq 3,0 \mathrm{~mm}$ em algum dente e no mesmo sítio, classificando-se a doença em localizada (menos de $30 \%$ dos dentes envolvidos), e generalizada (mais de $30 \%$ dos dentes afetados) (Armitage, 1999). Gengivite foi diagnosticada se: $\mathrm{PS}<4,0 \mathrm{~mm}$ e NCl$<3,0 \mathrm{~mm}$ em dois a cinco dentes; e periodontalmente sadia se: $\mathrm{PS} \leq 2,0 \mathrm{~mm}$ e $\mathrm{NCl} \leq 2,0 \mathrm{~mm}$ e nenhum sítio com sangramento gengival.

O diagnóstico clínico de periodontite crônica baseou-se nas seguintes características: (1) Prevalência maior em adultos podendo ocorrer em crianças e adolescentes; (2) Taxas de progressão baixas a moderadas; (3) Quantidade de depósitos microbianos consistente com a severidade da destruição periodontal; (4) Nenhum padrão de agregação familiar, e (5) Presença freqüente de cálculo subgengival. Já o diagnóstico clínico da periodontite agressiva baseou-se nas suas 
formas localizada e generalizada. A forma localizada apresenta os seguintes aspectos clínicos: (1) Geralmente ocorre em adolescentes; (2) Taxa de progressão rápida; (3) A quantidade de depósitos microbianos não é consistente com a severidade da destruição; (4) Destruicão periodontal localizada em molares e incisivos permanentes; (5) Padrão familiar acentuado, e (6) Cálculo subgengival geralmente ausente. A forma generalizada possui as seguintes características clínicas: (1) Geralmente ocorre em indivíduos com até 30 anos de idade, mas pode acometer indivíduos acima dos 30 anos; (2) Taxa de progressão rápida; (3) A quantidade de depósitos microbianos em algumas vezes é consistente com a severidade da destruição; (4) A destruicão periodontal afeta mais dentes além dos molares e incisivos permanentes; (5) Padrão familiar acentuado, e (6) Cálculo subgengival pode ou não estar presente (Armitage, 2004).

\subsection{Coletas das amostras e os momentos da amostragem.}

As amostras clínicas, biofilme subgengival, exsudato vaginal, membrana amniônica e parênquima placentário foram obtidas de cada puérpera, totalizando 372 espécimes, segundo o Fluxograma 1. O momento da coleta dos espécimes seguiu uma ordem temporal (Fluxograma 2) de acordo com a admissão da gestante na Maternidade do HUCAM e com o tipo de parto realizado. Deste modo, na internação da gestante, o médico ginecologista colheu o exsudato vaginal e realizou outros procedimentos clínicos, laboratoriais e radiológicos. Após o parto, no período entre 24 a 48 horas procedeu-se ao exame clínico bucal com auxílio de foco de luz fixo (crânio do profissional), sonda periodontal, espelho clínico bucal, gorro, máscara, luvas estéreis e gazes. Imediatamente após, procedeu-se à coleta do biofilme subgengival para as puérperas de parto a termo ou pretermo. As placentas secundadas em plásticos esterilizados e estocadas à $4^{\circ} \mathrm{C}$ foram enviadas ao laboratório de patologia visando a remoção da membrana amniônica e do parênquima placentário, também no período máximo de até 48 horas durante seis meses para todas as puérperas do estudo. 
Fluxograma 1 - Material clínico coletado de diferentes fontes e a possível relação com desfechos reprodutivos e infecciosos.

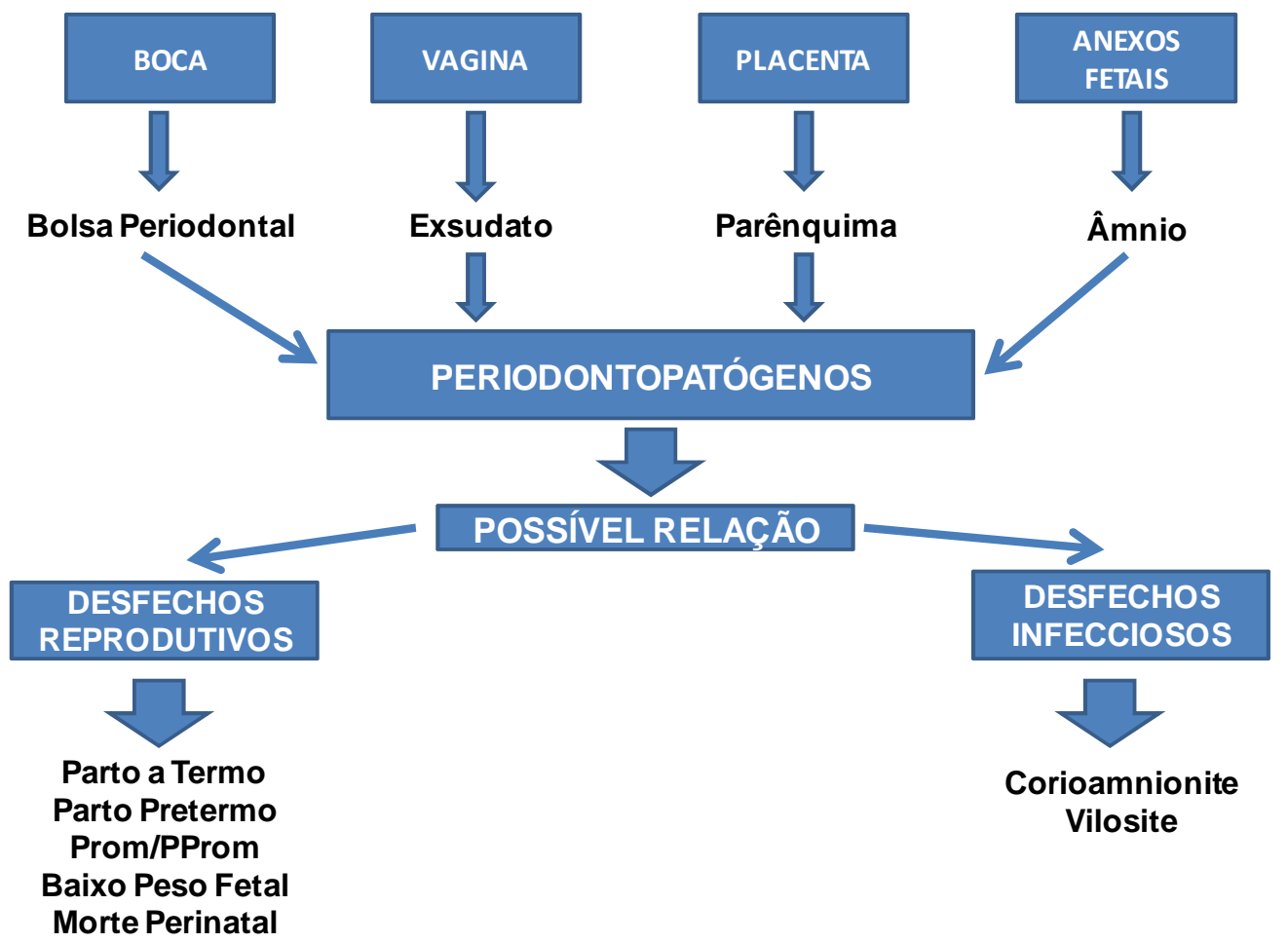

Fluxograma 2 - Momento da coleta dos diferentes espécimes clínicos entre as puérperas do HUCAM.

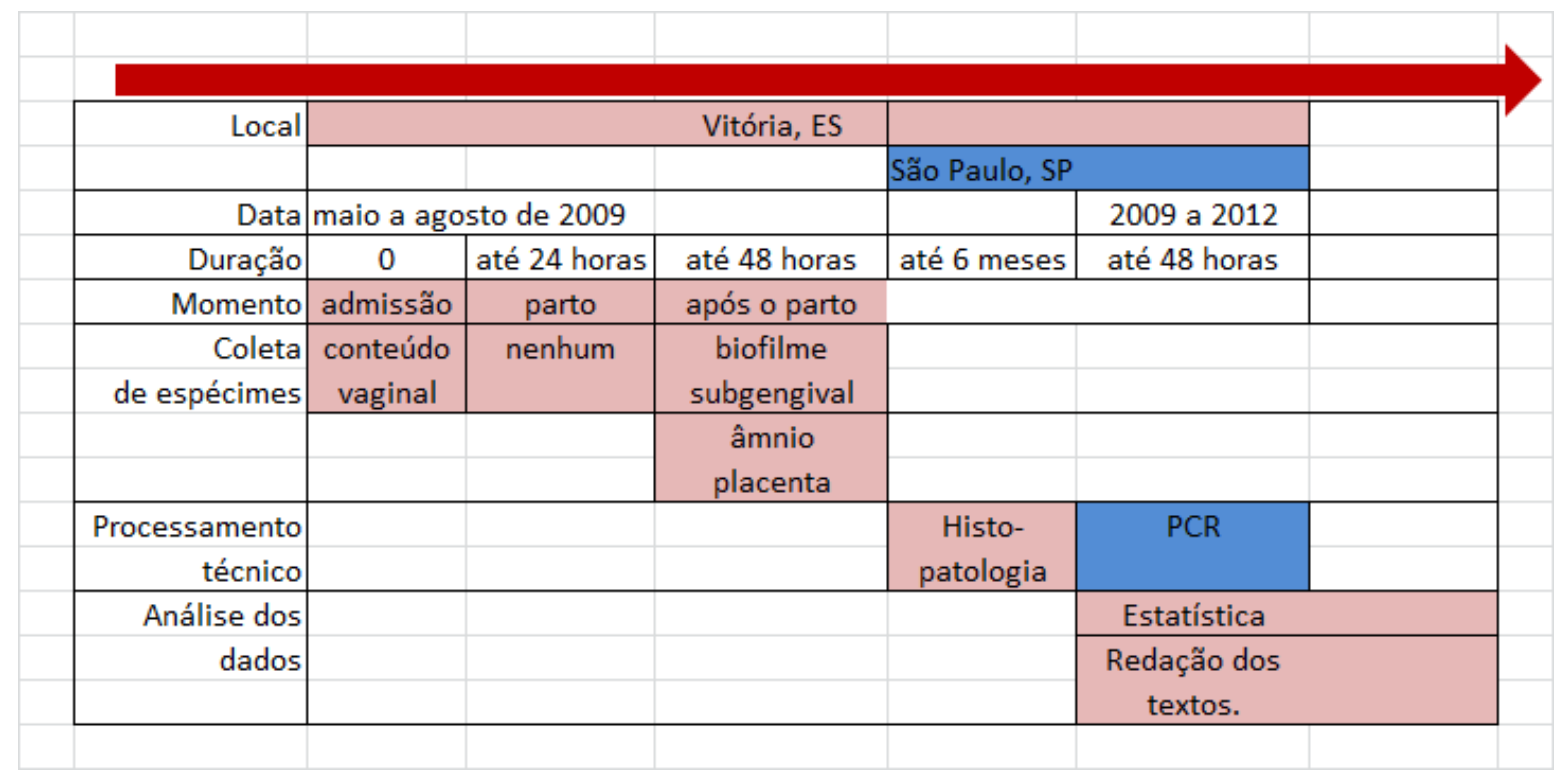


Figura 1 - Desenho esquemático da placenta e dos sítios coletados.

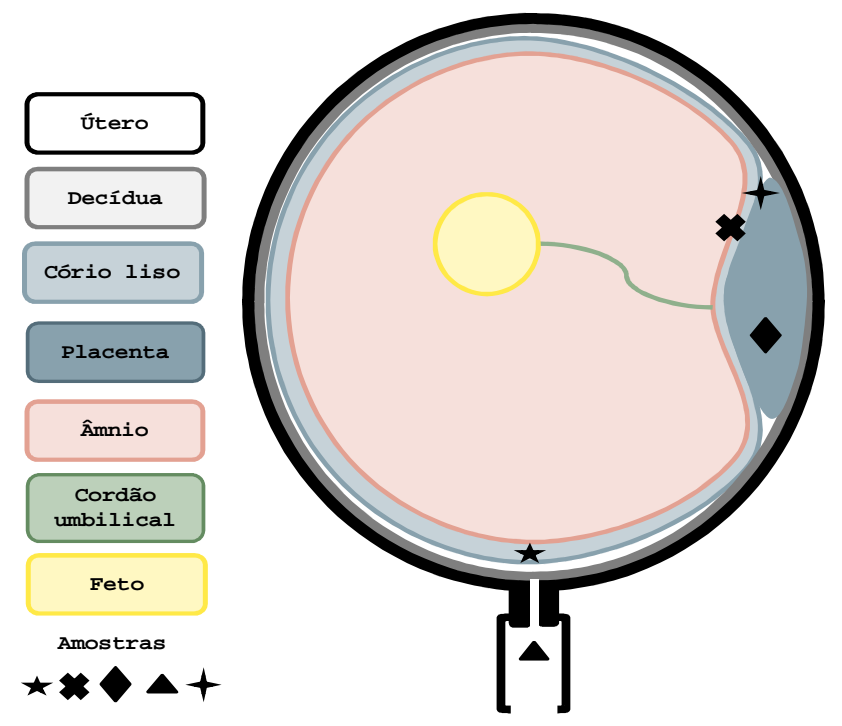

FONTE: Merçon-De-Vargas PR, Salim RC. 2011; Serviço de Patologia/HUCAM/UFES.

Figura 2 - Coleta da membrana amniônica.

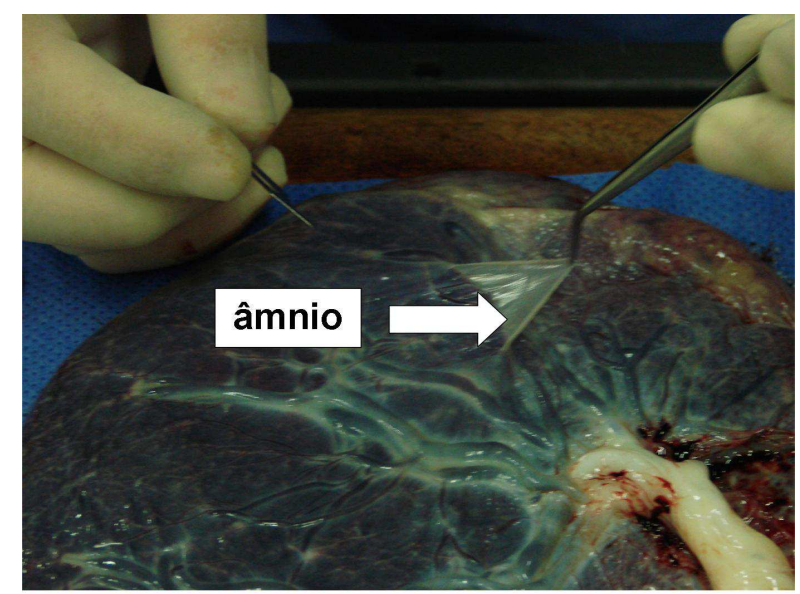

FONTE: Merçon-De-Vargas PR. 2011; Serviço de Patologia/HUCAM/UFES. 
Figura 3 - Coleta de parênquima placentário

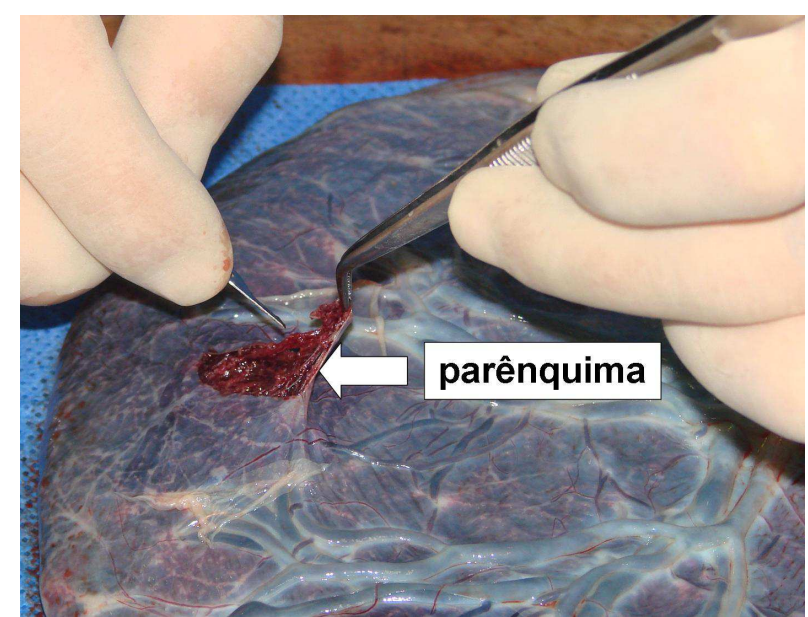

FONTE: Merçon-De-Vargas PR. 2011; Serviço de Patologia/HUCAM/UFES.

\subsubsection{Cavidade bucal}

\subsubsection{Biofilme subgengival}

Os espécimes subgengivais foram coletados durante o exame clínico periodontal, após profilaxia dos dentes com o uso de gazes e curetas periodontais visando à remoção do biofilme supragengival e/ou do cálculo dentário. Quatro amostras subgengivais (bolsas mais profundas ou de gengivite) foram coletadas com cones de papel absorventes esterilizados (No. 35, Tanari, São Paulo, SP, Brasil) e mantidos nos sítios por 30 segundos. Em seguida, os cones foram transferidos para tubos contendo $500 \mu \mathrm{l}$ de TE e estocados a $-80^{\circ} \mathrm{C}$. 
Figura 4 - Biofilme subgengival coletado com cones de papel inseridos na bolsa periodontal.

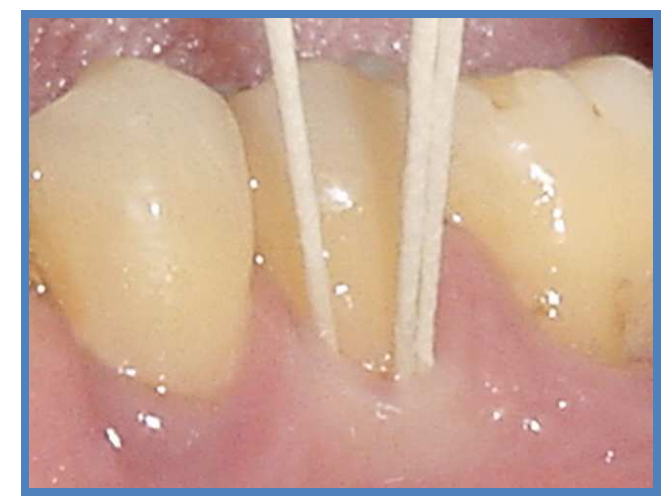

FONTE: Feitosa ACRF. 2011; Periodontia/UFES.

\subsubsection{Trato vaginal}

\subsubsection{Secreção cérvico-vaginal}

De cada gestante, no exame clínico de internação (antes do parto, admissão a maternidade do HUCAM), o obstetra coletou uma amostra da secreção vaginal com auxílio de cotonete esterilizado que foi transferida para tubo criogênico e conservado $\mathrm{a}-80^{\circ} \mathrm{C}$.

\subsubsection{Placenta e âmnio}

Logo após o nascimento da criança, a placenta foi secundada e acondicionada em saco plástico esterilizado, e transportada até o laboratório de Patologia sob refrigeração. Fragmentos de âmnio placentário (500mg a 1g) obtidos por meio de lamina de bisturi nํ.15C e de parênquima placentário (aspirado com agulha $n^{0} 18$ ) foram coletados por patologista auxiliado pelo periodontista (Figuras 2 e 3), e transferidos para tubos criogênicos e mantidos a -80 ํ․ Após esta coleta, os espécimes foram fixados em formaldeído (4\%) para posterior exame anátomopatológico.

\subsubsection{Exame anátomo-patológico dos anexos fetais}

Os anexos fetais foram examinados macro e microscopicamente de acordo 
com protocolo sistemático e estruturado (Merçon-De-Vargas, 1992), sem conhecimento dos informes clínicos ou dos resultados dos exames microbiológicos. O critério diagnóstico de corioamnionite (CAM) foi a presença de neutrófilos no cório ou no âmnio placentários (Altshuler, 1997; Benirschke et al., 2006; Fox e Langley, 1971).

\subsection{Análise microbiológica}

As amostras clínicas da cavidade bucal, vagina, placenta e âmnio foram avaliados microbiologicamente segundo o Fluxograma 1.

\subsubsection{Extração de DNA bacteriano das amostras clínicas}

As quatro amostras de biofilme subgengival de cada puérpera obtidas com cones de papel absorventes foram transferidas para um novo tubo eppendorf esterilizado visando realizar um pool destes espécimes. Em seguida, os tubos contendo os espécimes foram agitados em vortex (40 segundos), submetidos à centrifugação (14.000 rpm) por 10 minutos e posteriormente, à extração dos respectivos DNA bacterianos pelo método fenol-clorofórmio modificado (AvilaCampos et al., 1999a,b). Às amostras com secreção vaginal foram adicionadas tampão TE (300ul), aguardou-se a eluição (um minuto), agitou-se em vortex (40 segundos), submeteu-se à centrifugação (14.000 rpm) por 10 minutos e posteriormente, à extração dos respectivos DNA bacterianos pelo método fenolclorofórmio modificado. As membranas amnióticas foram removidas dos tubos criogênicos, cortadas em pequenos fragmentos com tesoura serrilhada e trituradas com bastão de vidro esterilizado em placas de Petri. Logo após, fragmentos com cerca de 200 a 300mg foram transferidas para tubos eppendorf contendo tampão TE (300ul), agitados por um minuto, centrifugados e submetidos à extração dos DNA bacterianos pelo método acima descrito. Quanto ao parênquima placentário foram transferidos $1,0 \mathrm{ml}$ de sangue para tubos eppendorf e procederam-se as demais etapas de acordo com o protocolo acima descrito.

\subsubsection{Detecção bacteriana pela reação em cadeia da polimerase (PCR)}

As amostras de DNA foram amplificadas utilizando-se iniciadores específicos 
segundo Ashimoto et al. (1996) e Avila-Campos et al. (1999a). As reações de amplificação do DNA bacteriano foram realizadas em volumes finais de $25 \mu \mathrm{l}$, contendo 10X de tampão PCR, $50 \mathrm{mM}$ de $\mathrm{MgCl}_{2}, 0,2 \mu \mathrm{M}$ da mistura de dNTP, 0,4 $\mu \mathrm{M}$ de cada iniciador específico, $5 \mathrm{U}$ de platinum Taq DNA polimerase, e $1 \mathrm{ng}$ de DNA. A reação de amplificação foi realizada em termociclador (Perkin-Elmer, Gene Amp PCR System 9700, Norwalk, CT, USA) programado de acordo com as condições descritas na Tabela 1. Foram usados como controles positivos DNA de cepas de referência: A. actinomycetemcomitans ATCC 29523, F. nucleatum ATCC 25586, P. gingivalis ATCC 33277, e T. forsythia ATCC 43037. Em todas as reações os DNA genômicos foram substituídos por água Milli-Q esterilizada como controle negativo. Os produtos de PCR $(20 \mu \mathrm{l})$ e o marcador molecular $1 \mathrm{~kb}$ plus DNA (Invitrogen do Brasil Ltda., São Paulo, Brasil) foram analisados por eletroforese (90 $\mathrm{V}, 2$ horas) em gel de agarose a $1 \%$, sendo posteriormente, corados com brometo de etídio $(0,5 \mu \mathrm{g} / \mathrm{ml})$, visualizados sob luz ultravioleta e fotografados com sistema Kodak Digital Science-120.

\begin{tabular}{|c|c|c|c|c|c|}
\hline Bactéria alvo & Sequência de iniciadores $\left(5^{\prime}-3^{\prime}\right)$ & $\begin{array}{l}\text { Condiçôes } \\
\text { (ciclos, temperatura, tempo) }\end{array}$ & $\begin{array}{l}\text { Temperatura } \\
\text { anelamento }\end{array}$ & $\begin{array}{l}\text { Amplificação } \\
\text { (bp) }\end{array}$ & Referências \\
\hline $\begin{array}{l}\text { Universal Primers } \\
165 \text { rRNA }\end{array}$ & $\begin{array}{l}\text { AGA GTT TGA TCC TGG CTC AG } \\
\text { CAA TAC TCG TAT CGC CCG TTA TTC }\end{array}$ & $\begin{array}{l}1 \text { ciclo 940C; } 30 \text { ciclos: } 940 \mathrm{C} \times 30,56^{\circ} \\
\mathrm{C} \times 30^{\prime \prime}: 56^{\circ} \mathrm{C} \times 30^{\prime \prime} .72^{\circ} \mathrm{C} \times 1^{\prime}: 1 \text { ciclo } 72^{\circ} \mathrm{C} \times 5^{\prime}\end{array}$ & 60 & 1500 & Amano etal 1999 \\
\hline A. actinomycetemcomitans & $\begin{array}{l}\text { AAA CCC ATC TCT GAG TTC TTC TTC } \\
\text { ATG CCA ACT TGA AGT TAA AT }\end{array}$ & $\begin{array}{l}1 \text { ciclo de } 94^{\circ} \mathrm{C} 5^{\prime}, 30 \text { ciclos } 94^{\circ} \mathrm{C} 30^{\prime \prime}, 560 \mathrm{C} \\
30^{\prime \prime} .72^{\circ} \mathrm{C} 30^{\prime \prime} .1 \text { ciclo } 72^{\circ} \mathrm{C} 5^{\prime \prime}\end{array}$ & 56 & 557 & Ashimoto et al 1996 \\
\hline F. nucleatum & $\begin{array}{l}\text { ATT GTG GCT AAA AAT TAT AGT T } \\
\text { ACC CTC ACT TTG AGG ATT ATAG }\end{array}$ & $\begin{array}{l}1 \text { ciclo } 94^{\circ} \mathrm{C} 5^{\prime}, 30 \text { ciclos } 94^{\circ} \mathrm{C} 30^{\prime \prime}, x x x \\
\text { ciclos } 50^{\circ} \mathrm{C} 30^{\prime \prime} . x x \text { ciclos } 72^{\circ} \mathrm{C} 30^{\prime \prime} .1\end{array}$ & 40 & 500 & Ávila-Campos 1996 \\
\hline P. gingivalis & $\begin{array}{l}\text { AGG CAG CTT GCC ATA CTG CG } \\
\text { ACT GTT AGC AAC TAC CGA TGT }\end{array}$ & $\begin{array}{l}1 \text { ciclo } 94^{\circ} \mathrm{C} 5^{\prime} ; 35 \text { ciclos } 94^{\circ} \mathrm{C} 30^{\prime \prime}, \mathrm{XX} \\
\text { cirlos } 60^{\circ} \mathrm{C} 30^{\prime \prime} .77^{\circ} \mathrm{C} 30^{\prime \prime} .1 \text { cirlo } 77^{\circ} \mathrm{C} .7^{\prime}\end{array}$ & 60 & 404 & Ashimoto et al 1996 \\
\hline T. forsythia & $\begin{array}{l}\text { GCC TAT GTA ACC TGC CCG CA } \\
\text { TGC TTC AGT GTC AGT TAT ACC T }\end{array}$ & $\begin{array}{l}1 \text { ciclo } 94^{\circ} \mathrm{C} 5^{\prime}, 30 \text { ciclos } 94^{\circ} \mathrm{C} 30^{\prime \prime}, \text { XXX } \\
\text { ciclos } 60^{\circ} \mathrm{C} 1^{\prime} . X X X \text { ciclos } 72^{\circ} \mathrm{C} 2^{\prime} .1 \text { ciclo }\end{array}$ & 60 & 641 & Ashimoto et al 1996 \\
\hline
\end{tabular}

\subsection{Análise estatística}

A análise estatística consistiu na determinação da ocorrência uni-variada (freqüência simples) ou bi-variada (valor $p$, Intervalo de Confiança - IC, QuiQuadrado - $x^{2}$, Incremento Direto - ID, Odds ratio - OR, Razão Simples - RS e 
Número necessário para o efeito - NNE) das variáveis, doença periodontal (DP) e bactéria periodontopatogênica (BPPG), nos vários sítios e das variáveis obstétricas na amostra como um todo, e comparativamente nos casos com corioamnionite (CAM) e com quatro desfechos reprodutivos ruins (DRR): PROM/PPROM, PPT, BPN e MPN. O contraste entre as freqüências foi sumarizado: (1) pelo incremento direto (ID), isto é, a diferença entre as proporções do fator (causa) na presença e na ausência do DRR (efeito), calculada como $((a / n)-(b / n))$, considerando um valor superior a 0,20 (20\%) um contraste de magnitude significativo (Feinstein, 2002) e (2) pela odds ratio (OR), uma aproximação do risco relativo que revela quantas vezes é mais (ou menos) comum o efeito na presença do fator (causa) em relação à ausência do fator. Empregaram-se fórmulas descritas por Feinstein (2002) e tabelas de contingência recomendadas por Tukey (1977). Nenhuma tentativa foi feita para controlar os fatores de confusão ou para ajustar as estimativas das comparações múltiplas. A principal motivação para esta decisão foi a pretensão de concentrar a análise nos aspectos substantivos do problema, bactérias periodontopatogênicas, doença periodontal, desfechos reprodutivos ruins e infecciosos (CAM e vilosite), mais condizentes com o objetivo preliminar de identificar as possíveis associações não independentes.

\subsection{Implicações Éticas}

Este estudo foi aprovado pelo Comitê de Ética em Pesquisa em Seres Humanos do Instituto de Ciências Biomédicas da Universidade de São Paulo (Proc. № 807/CEP). 


\section{RESULTADOS}

\subsection{Dados demográficos, obstétricos e fetais.}

A ocorrência das características sócio-demográficas, obstétricas e fetais da amostra como um todo se encontra na Tabela 2. As puérperas estudadas apresentam o típico perfil das gestantes brasileiras atendidas pelo SUS: 20,4\% eram adolescentes, $75,0 \%$ não brancas, $94,87 \%$ com menos de oito anos de educação, 31,2\% ocupavam-se do lar, $70,6 \%$ não civilmente casadas, 10,84\% atenderam menos de quatro consultas prenatais e $55,91 \%$ eram primigestas. Rotura prematura ou precoce de membranas fetais foi observada em $22,2 \%$, parto cesariano em $65,59 \%$, pretermo em $36,56 \%$, baixo peso fetal em $34,41 \%$, morte perinatal em $5,38 \%$, corioamnionite em $34,41 \%$ e vilosite em $8,6 \%$ dos casos.

\section{Tabela 2 - Dados demográficos, gestacionais, obstétricos e fetais.}

Idade materna em anos, mediana (IQR)

$25(20-30)$

Raça/etnia - não branca, $n$ (\%)

$69 / 92(75,00)$

Instrução - $<8$ anos, n (\%)

$74 / 78(94,87)$

Primigesta, $\mathrm{n}(\%)$

$52 / 93(55,91)$

Prenatal, $<6$ consultas, $\mathrm{n}(\%)$

$9 / 83(10,84)$

Tabagismo na gestação, $\mathrm{n}(\%)$

$7 / 92(7,61)$

Infecção urinária, $\mathrm{n}(\%)$

$11 / 90(12,22)$

Hipertensão arterial na gestação, $n(\%)$

$10 / 90(11,11)$

Diabetes melitus na gestação, $\mathrm{n}(\%)$

$4 / 90(4,44)$

Parto cesariano, $\mathrm{n}(\%)$

$61 / 93(65,59)$

Rotura de membranas fetais, $>12$ horas, $\mathrm{n}(\%)$

$16 / 91(17,58)$

Corioamnionite histológica, $\mathrm{n}(\%)$

$32 / 93(34,41)$

Vilosite, $\mathrm{n}(\%)$

$8 / 93(8,6)$

Idade gestacional em dias, média ( $\mathrm{dp}$ )

$259(28)$

Nascimento pretermo $<34$ semanas, $n(\%)$

$21 / 93(22,58)$

Nascimento pretermo $<37$ semanas, $n(\%)$

$34 / 93(36,56)$

Peso ao nascer, média (dp)

$2782(849)$

Baixo peso fetal ao nascer $(<2500 \mathrm{~g}), \mathrm{n}(\%)$

$32 / 93(34,41)$

Morte perinatal, $\mathrm{n}(\%)$

$5 / 93(5,38)$ 


\subsection{Dados clínicos bucais}

Os parâmetros clínicos dentários e periodontais estão apresentados na Tabela 3 e na Figura 5. Todas puérperas estudadas apresentaram alguma doença periodontal e $62,4 \%$ na forma de periodontite agressiva, com profundidade de bolsa periodontal mediana de 4,6 mm e nível clínico de inserção mediano de 3,8 mm; 72,04\% já haviam perdido algum dente e 83,87\% tinham cárie. Sangramento à sodagem foi observado em $22,6 \%$ dos sítios periodontais e $47 \%$ dos sítios apresentaram placa bacteriana. A periodontite agressiva foi mais prevalente $(62,3 \%)$ entre as puérperas, logo após, a periodontite crônica com 32,2\% e gengivite com 8,06\%. Cerca de $30 \%$ das puérperas apresentaram a extensão localizada da periodontite agressiva, enquanto se observou 33,3\% na forma generalizada desta infecção periodontal. Na periodontite crônica, as extensões localizadas e generalizadas nas puérperas atingiram $8,60 \%$ e $23,66 \%$, respectivamente.

\section{Tabela 3 - Dados Clínicos Bucais.}

Cáries, n (\%)

$78 / 93 \quad(83,87)$

Perda dentária, n (\%)

$67 / 93(72,04)$

Porcento de sítios com placa, mediana (IQR)

$47,01 \quad(29-62)$

$\%$ Profundidade de sondagem $\geq 4,0 \mathrm{~mm}$ média, mediana (IQR)

$12,06 \quad(5-17)$

\% Perda média de inserção $\geq 3,0 \mathrm{~mm}$, mediana (IQR)

$21,26 \quad(12-28)$

Porcento de sítios com sangramento à sondagem, mediana (IQR)

$22,59(10-30)$

Doença periodontal

Gengivite crônica, n (\%)

$5 / 93$

Periodontite

Crônica localizada, n (\%)

Crônica generalizada, $\mathrm{n}(\%)$

Agressiva localizada, $\mathrm{n}(\%)$ 


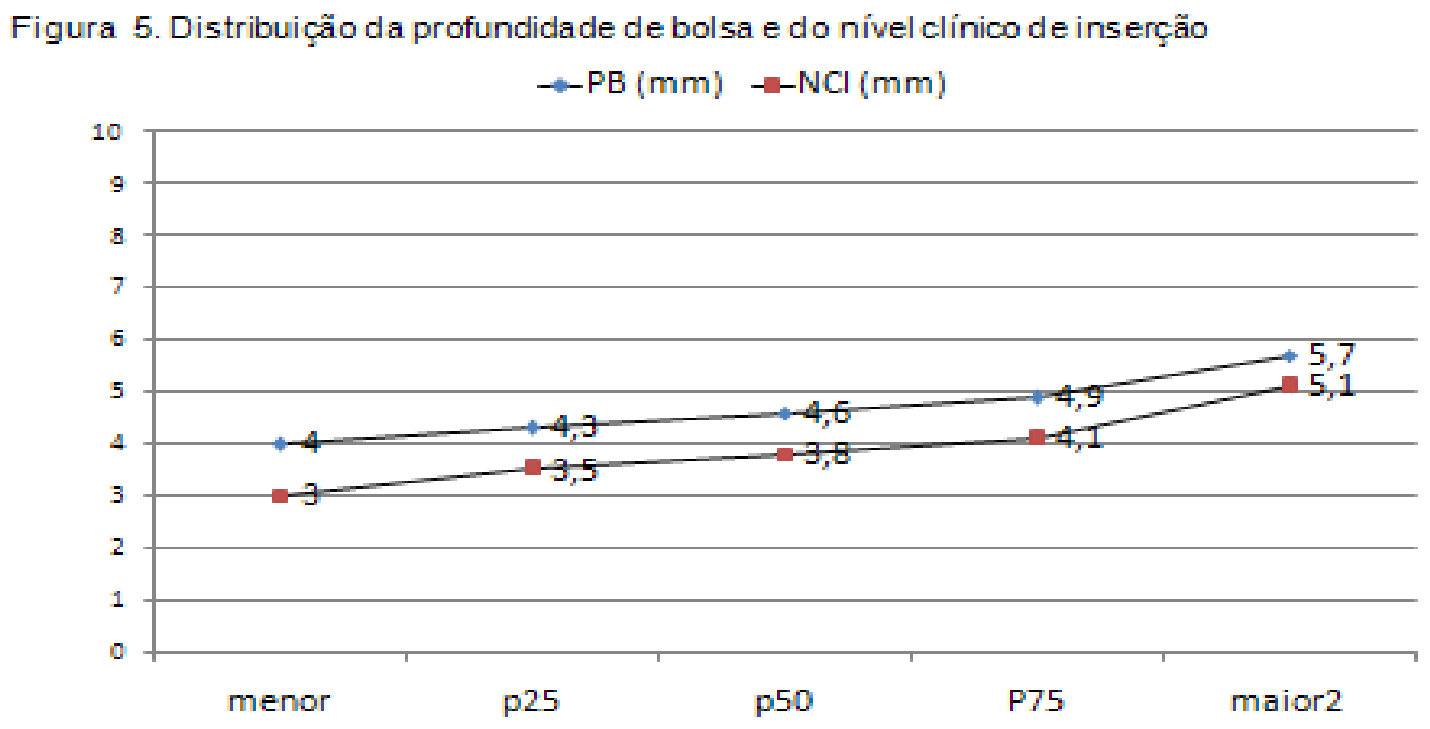

\subsection{Prevalência de bactérias periodontopatogênicas (BPPG)}

A freqüência absoluta de detecção de cada bactéria periodontopatogênica em cada sítio é apresentada na Tabela 4. Alguma bactéria periodontopatogênica foi encontrada em 120 (8,06\%) dos 1080 testes, das quais, 372 amostras clínicas examinadas corresponderam a $70(75,27 \%)$ das 93 puérperas estudadas (Figura 6). Todas as bactérias periodontopatogênicas avaliadas foram encontradas no biofilme subgengival (boca) e no trato genital inferior (vagina). Os periodontopatógenos $F$. nucleatum e $P$. gingivalis foram detectados em todos os sítios. Nenhum $A$. actinomycetemcomitans foi encontrado na membrana amniônica e no parênquima placentário das puérperas. $T$. forsythia esteve presente nos sítios biofilme, vagina e parênquima placentário, mas não no âmnio. $P$. gingivalis foi o mais prevalente das BPPG na amostra como um todo. Somente dois periodontopatógenos foram encontrados no âmnio, $P$. gingivalis e $F$. nucleatum. A prevalência de cada periodontopatógeno em todos os sítios foi: $A$. actinomycetemcomitans em 5/93 (5,37\%), P. gingivalis em 59/93 (63,33\%), F. nucleatum em 23/93 (24,73\%) e T. forsythia em 33/93 (35,48\%) das puérperas. No biofilme subgengival, $A$. actinomycetemcomitans foi observado em 2/93 (2,16\%), $P$. gingivalis em $30 / 93(32,25 \%$, F. nucleatum em 16/93 (17,11\%) e T. forsythia em 
29/93 (31,18\%) das gestantes (Tabela 4). Em 22,85\% (16/70) das puérperas foram observados dois periodontopatógenos e três em 7,14\% (5/70) das puérperas (Figura 7).

Todas as bactérias periodontopatogênicas foram detectadas na vagina (Tabela 4), com as seguintes distribuições: $A$. actinomycetemcomitans em 3/93 (3,22\%), P. gingivalis em 16/93 (17,11\%), F. nucleatum em 2/93 (2,16\%), e T. forsythia em $3 / 93$ (3,22\%). Nas amostras vaginais houve duas associações: uma puérpera com $A$. actinomycetemcomitans e $P$. gingivalis e outra com $F$. nucleatum e T. forsythia (Figura 8).

Apenas dois periodontopatógenos foram detectados no âmnio (Tabela 4): $F$. nucleatum em 4/93 (4,30\%) e $P$. gingivalis em 9/93 (9,67\%), além de uma puérpera apresentar as duas bactérias periodontopatogênicas (Figura 9).

No parênquima placentário foram observados três periodontopatógenos em cinco puérperas (Tabela 4): F. nucleatum em 1/93 (1,08\%) e $P$. gingivalis em 4/93 $(4,30 \%)$ e uma única puérpera com dois periodontopatógenos, $P$. gingivalis e $T$. forsythia (Figura 10).

Tabela 4 - Distribuição topográfica de bactérias periodontopatogênicas em 93 puérperas.

\begin{tabular}{lcccccc}
\hline & Todos os & Boca & Vagina & \multicolumn{2}{c}{ Placenta } \\
& sítios & & & Âmnio & Parênquima \\
\cline { 5 - 7 } & $\mathrm{n}(\%)$ & $\mathrm{n}(\%)$ & $\mathrm{n}(\%)$ & $\mathrm{n}(\%)$ & $\mathrm{n}(\%)$ \\
\hline A. actinomycetemcomitans & $5(5,38)$ & $2(2,15)$ & $3(3,23)$ & $0(0,00)$ & $0(0,00)$ \\
F. nucleatum & $23(24,73)$ & $16(17,20)$ & $2(2,15)$ & $4(4,30)$ & $1(1,08)$ \\
$\boldsymbol{P}$. gingivalis & $59(63,44)$ & $30(32,26)$ & $16(17,20)$ & $9(9,68)$ & $4(4,30)$ \\
T. forsythia & $33(35,48)$ & $29(31,80)$ & $3(3,23)$ & $0(0,00)$ & $1(1,08)$ \\
\hline
\end{tabular}


Figura 6 - Presença de algum periodontopatógeno em qualquer sítio avaliado.

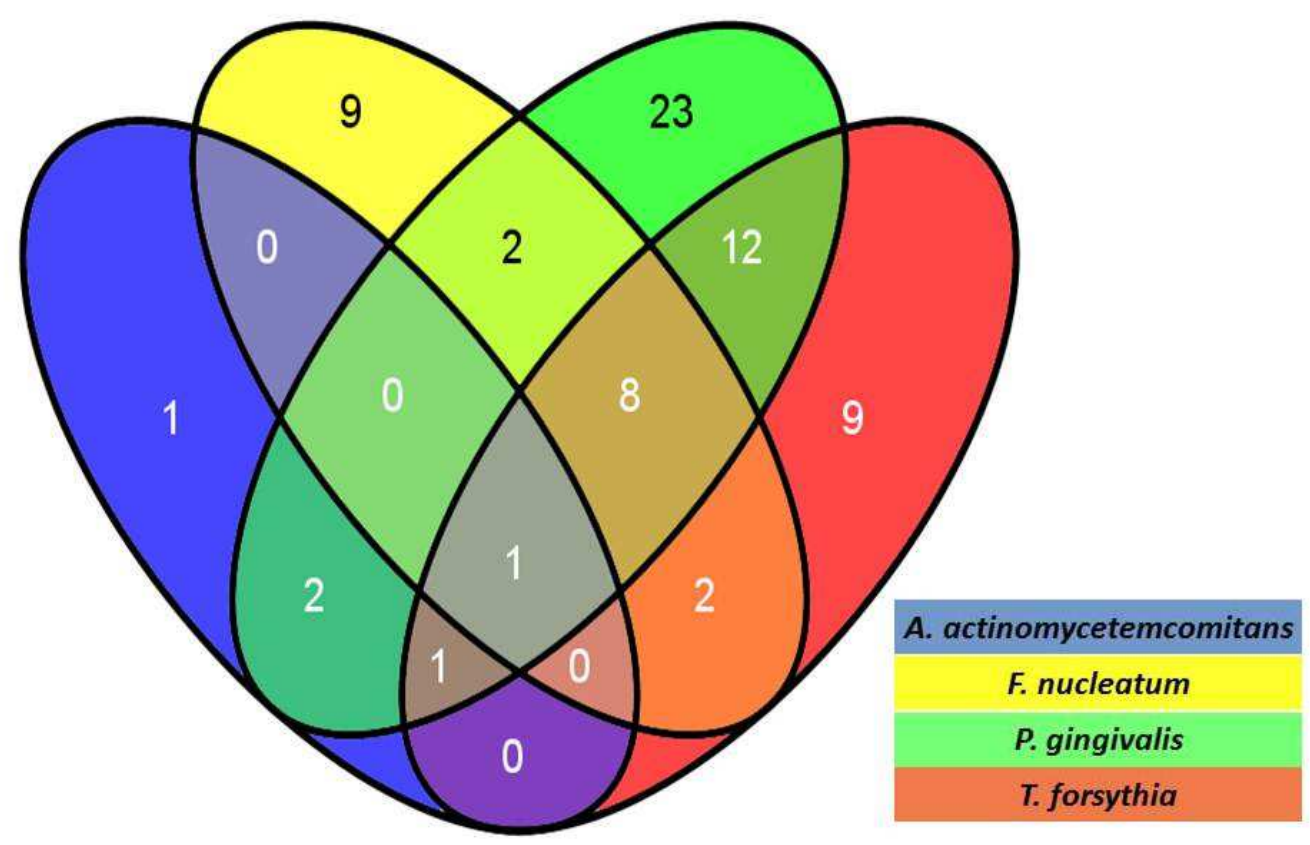

Figura 7 - Presença de bactérias periodontopatogênicas nas amostras de biofilme subgengival.

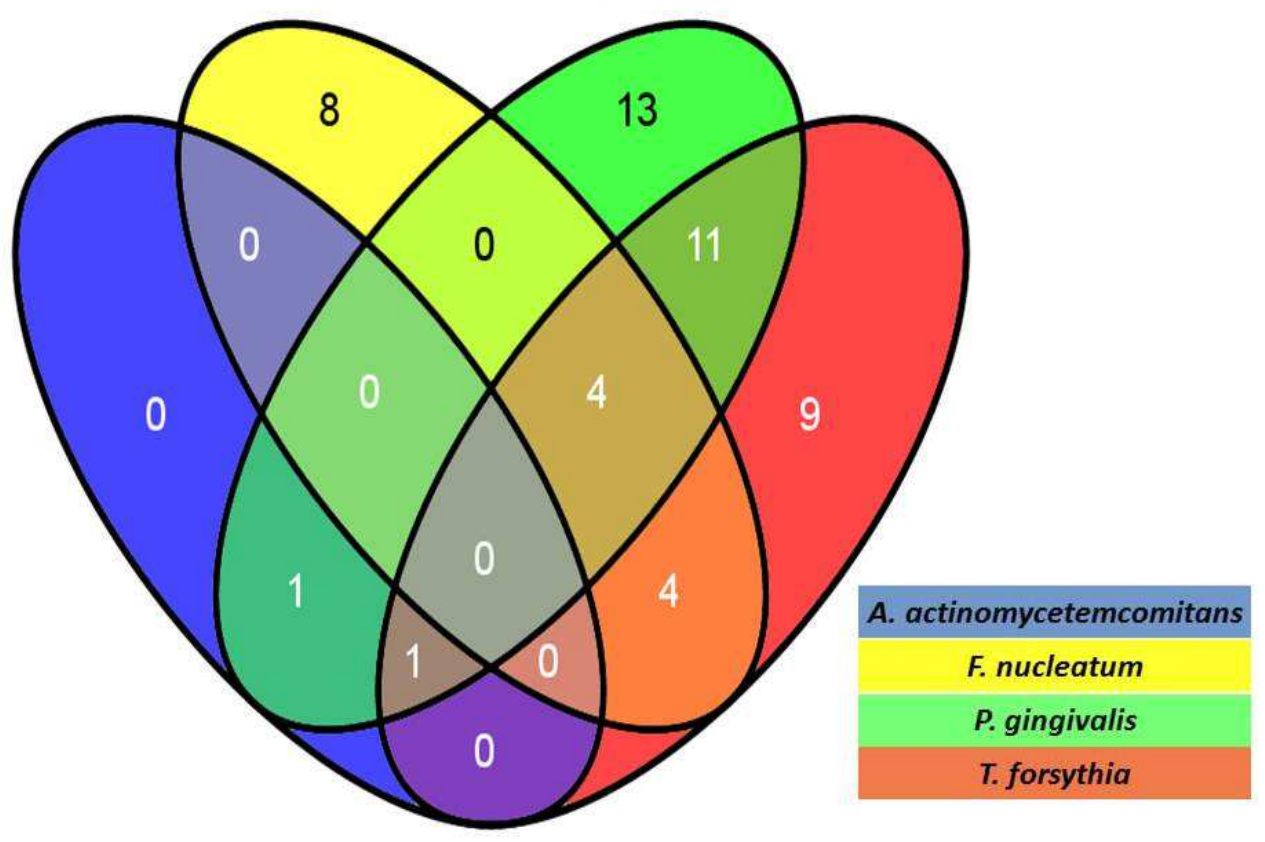


Figura 8 - Presença de bactérias periodontopatogênicas nas amostras vaginais.

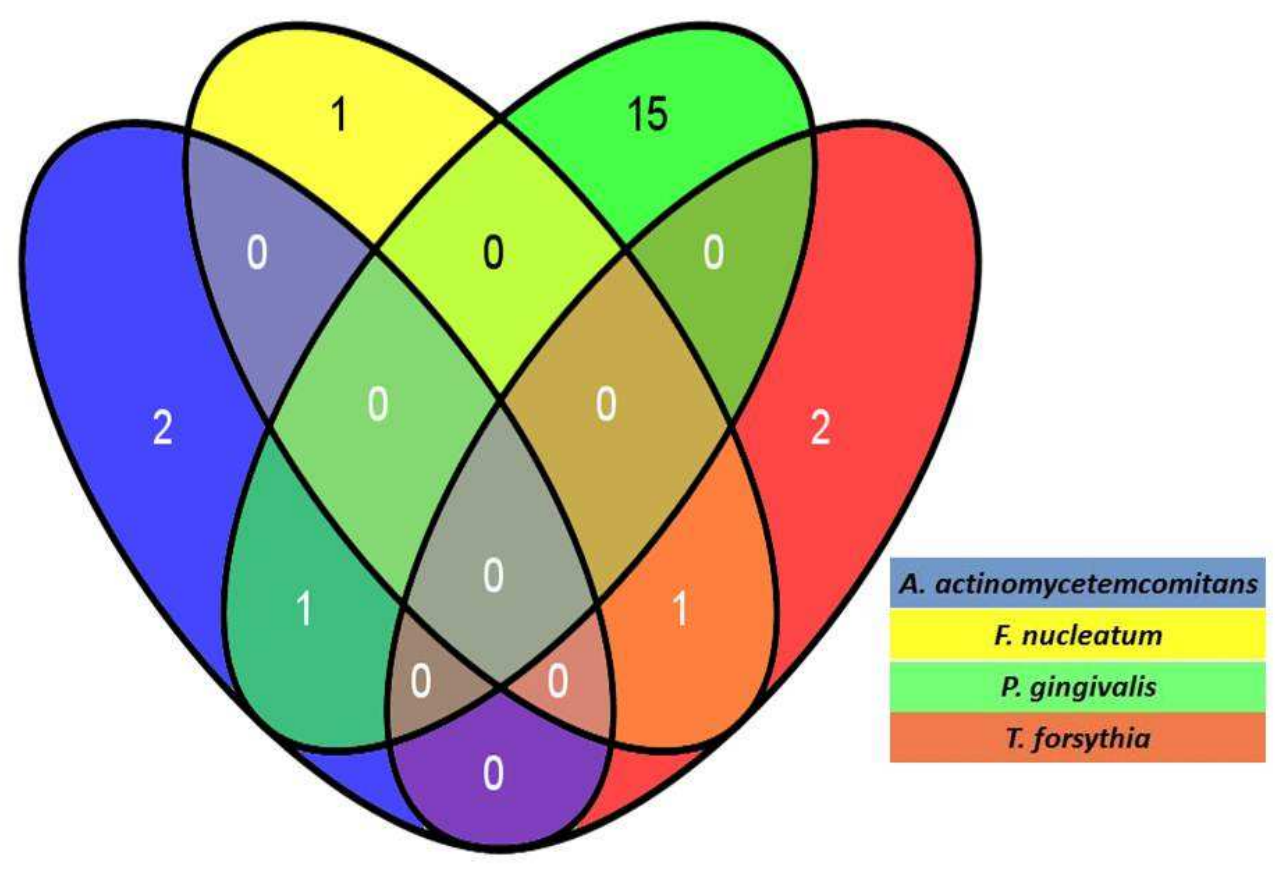

Figura 9 - Presença de bactérias periodontopatogênicas nas amostras amnióticas.

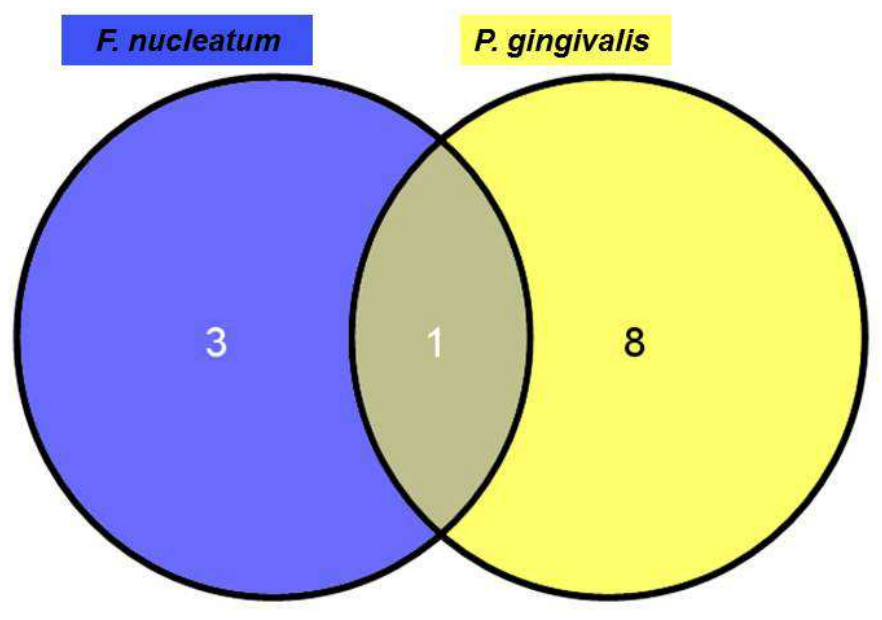


Figura 10 - Presença de bactérias periodontopatogênicas nas amostras de placenta.

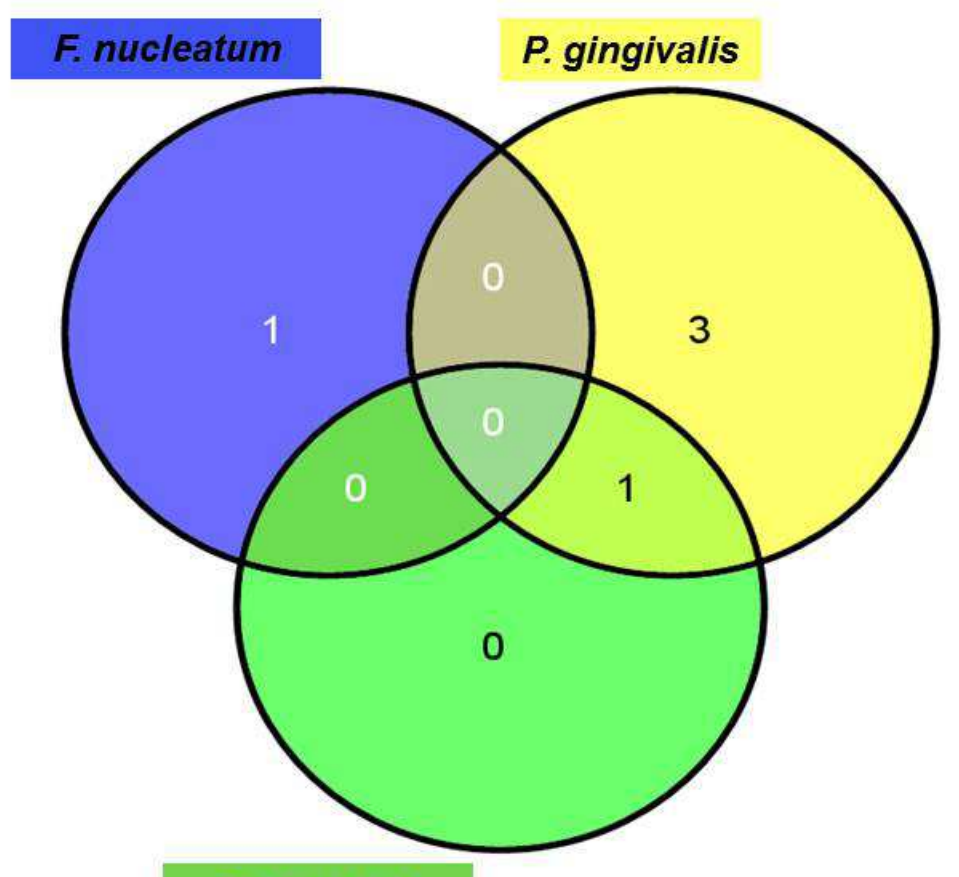

T. forsythia

5.4 Disseminação de bactéria periodontopatogênica (BPPG).

5.4.1 Disseminação da boca (biofilme subgengival) para a vagina.

Apenas P.gingivalis foi detectado simultaneamente em ambos os sítios par, boca e vagina da mesma puérpera (Figura 11), correspondendo a $20,0 \%(6 / 30)$ da taxa de disseminação e a 37,5\% (6/16) da taxa de proporção. 
Figura 11 - Presença de P.gingivalis em dois sítios analisados.

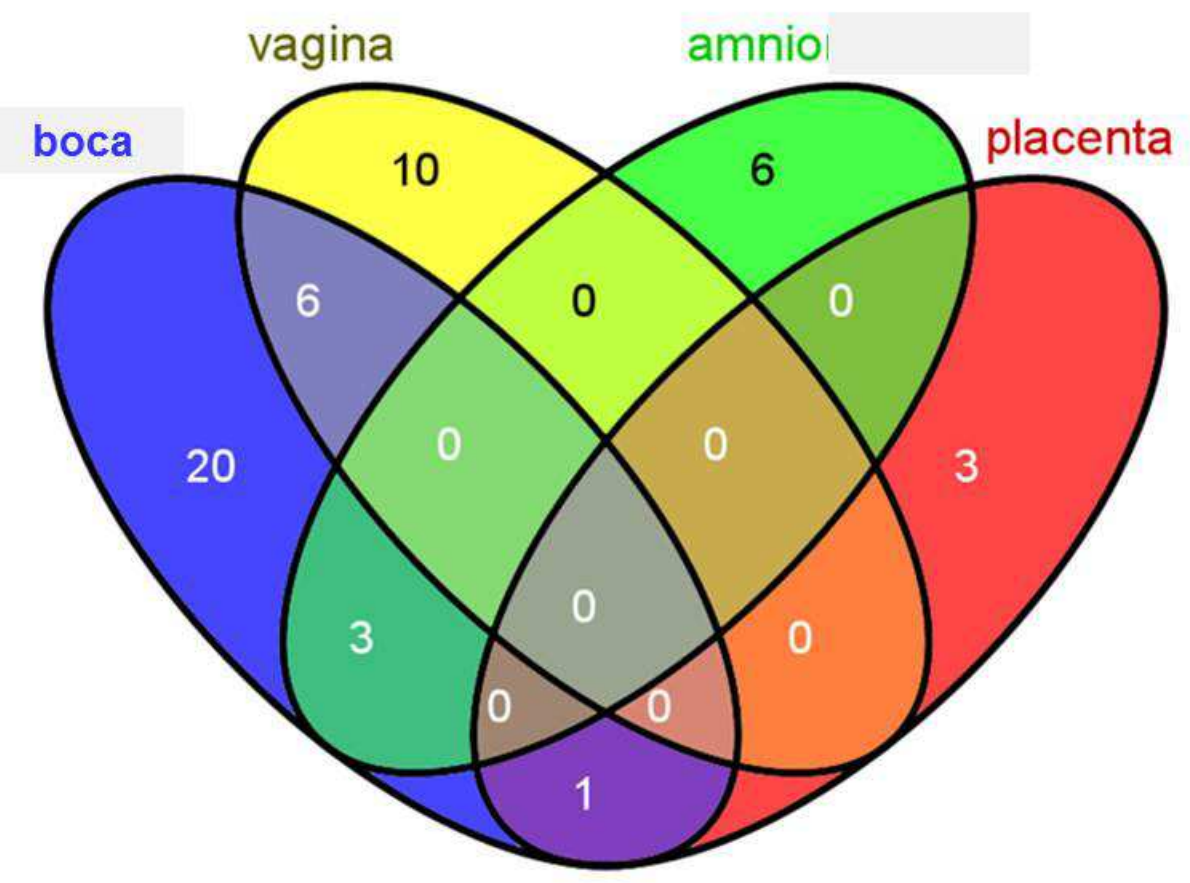

\subsubsection{Disseminação da boca para o âmnio.}

Foi observada disseminação da boca para o âmnio de F. nucleatum em 1/16 (6,25\%) (Figura 12) e de P.gingivalis em 3/30 (10.0\%) (Figura 11), correspondendo a uma taxa de proporção de $1 / 4(25,0 \%)$ e de 3/10 (30,0\%), respectivamente. Nenhum outro periodontopatógeno foi detectado no sítio par boca e âmnio.

\subsubsection{Disseminação da boca para o parênquima placentário.}

Houve apenas uma puérpera entre as 30 (3,33\%) que disseminou P.gingivalis da boca para o parênquima placentário, correspondendo a 1/4 $(25,0 \%)$ da taxa de proporção (Figura 11). Nenhum outro periodontopatógeno foi detectado no sítio par boca e parênquima placentário. 


\subsubsection{Disseminação da vagina para o âmnio.}

Nenhuma detecção simultânea de bactéria periodontopatogênica na vagina e âmnio foi observada (Figuras 11, 12 e 13).

\subsubsection{Disseminação do âmnio para o parênquima placentário.}

Houve nenhuma detecção simultânea de qualquer bactéria periodontopatogênica no âmnio e parênquima placentário (Figuras 11, 12 e 13).

Figura 12 - Presença de F.nucleatum nos sítios analisados.

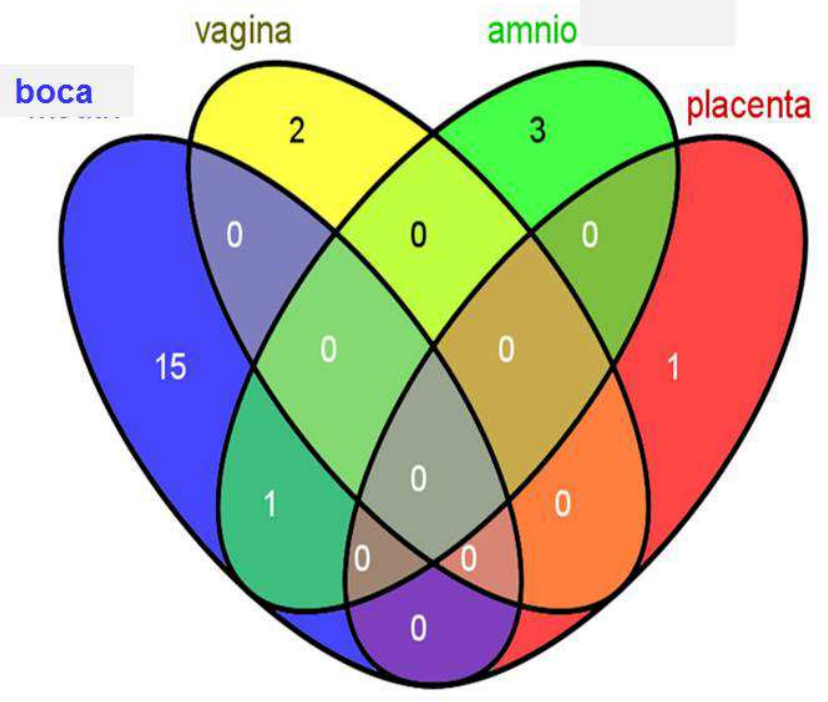

Figura 13 - Presença de T.forsythia nos sítios analisados.

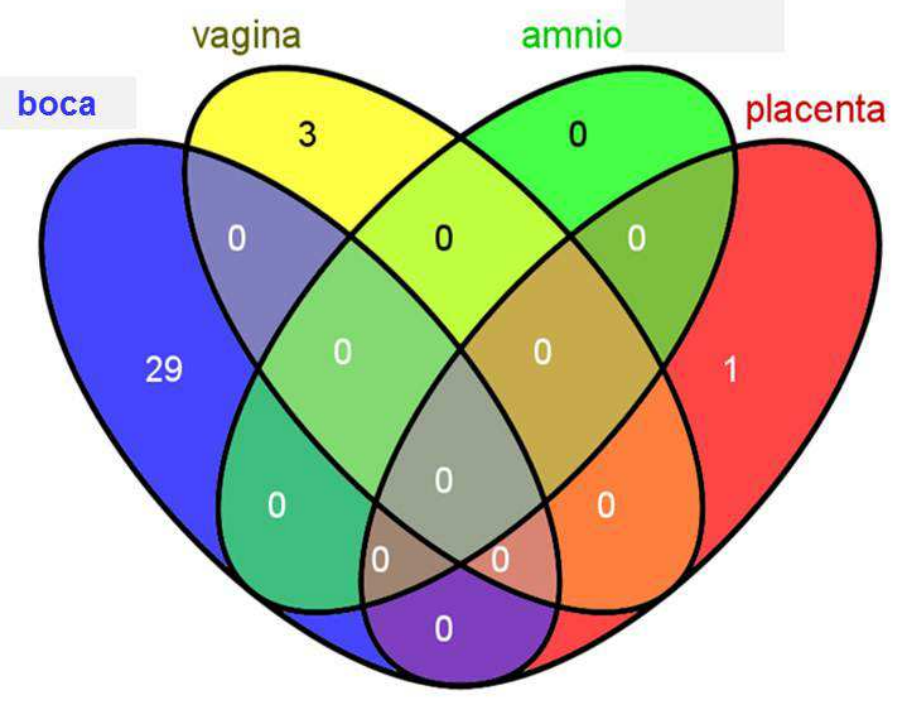




\subsection{Associações entre doença periodontal (DP), bactérias periodontopatogênicas (BPPG) e desfechos reprodutivos ruins (DRR).}

\subsubsection{Doença periodontal e desfechos reprodutivos ruins.}

A periodontite agressiva associou-se com maior frequência em relação ao ínicio do trabalho de parto nas terminações a termo espontâneo (ID=23\%, Figura 14); com rotura das membranas fetais 24 horas ou mais (ID=22\%, Figura 15); com menor contraste para parto pretermo (ID $=10 \%$, Figuras 16); parto muito pretermo (ID=10\%, Figura 17); e baixo peso fetal ao nascer (ID=15\%, Figura 18), mas sem significância estatística. Não houve qualquer outra associação significante entre doença periodontal e desfecho reprodutivo ruim, tais como, periodontite e corioamnionite, periodontite e vilosite, e periodontite e morte perinatal.

Figura 14 - Início do trabalhode parto nas terminações a termo.

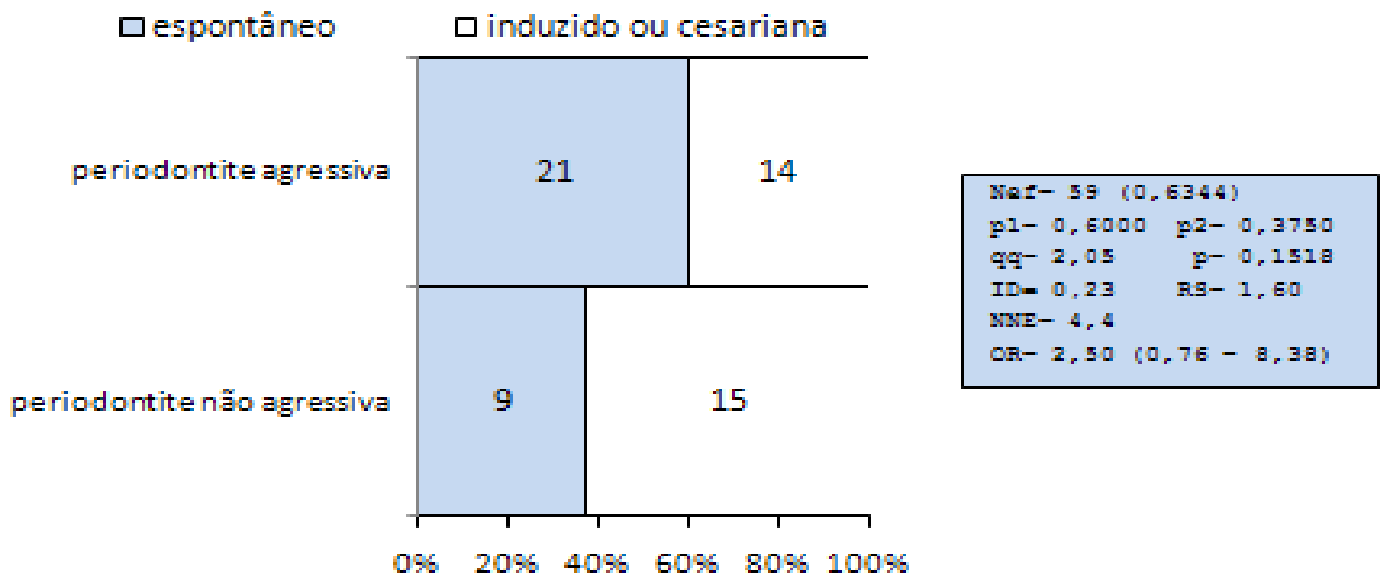


Figura 15 - Rotura prolongada das membranas fetais.

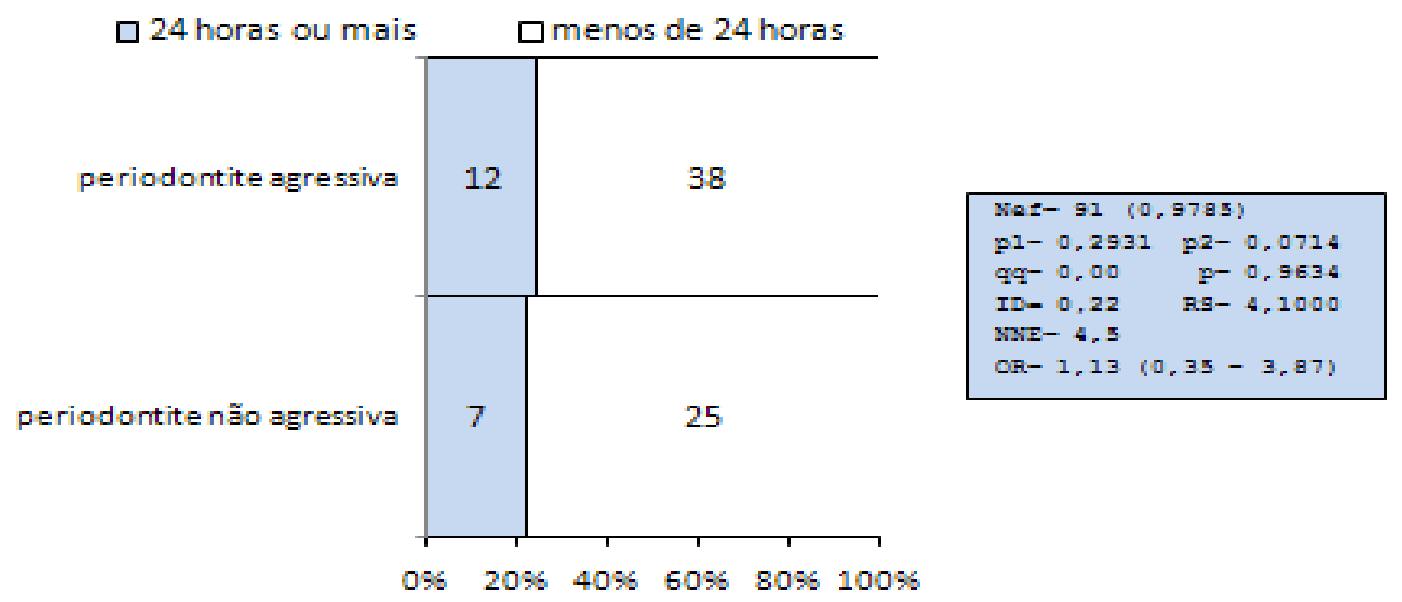

Figura 16-Parto pretermo.

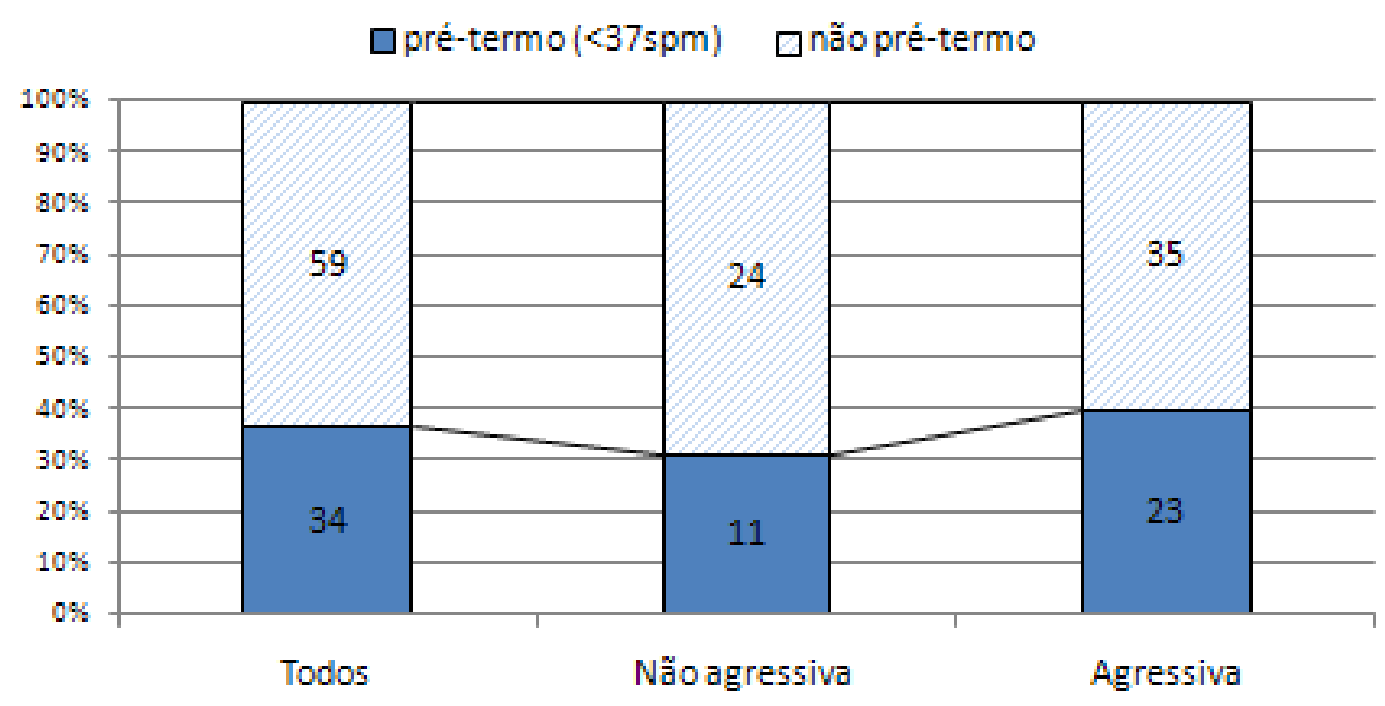

Periodontite 
Figura 17 - Parto muito pretermo.

$\square$ pretermo (24 a 33spm) Q não pretermo (37 a 42spm)

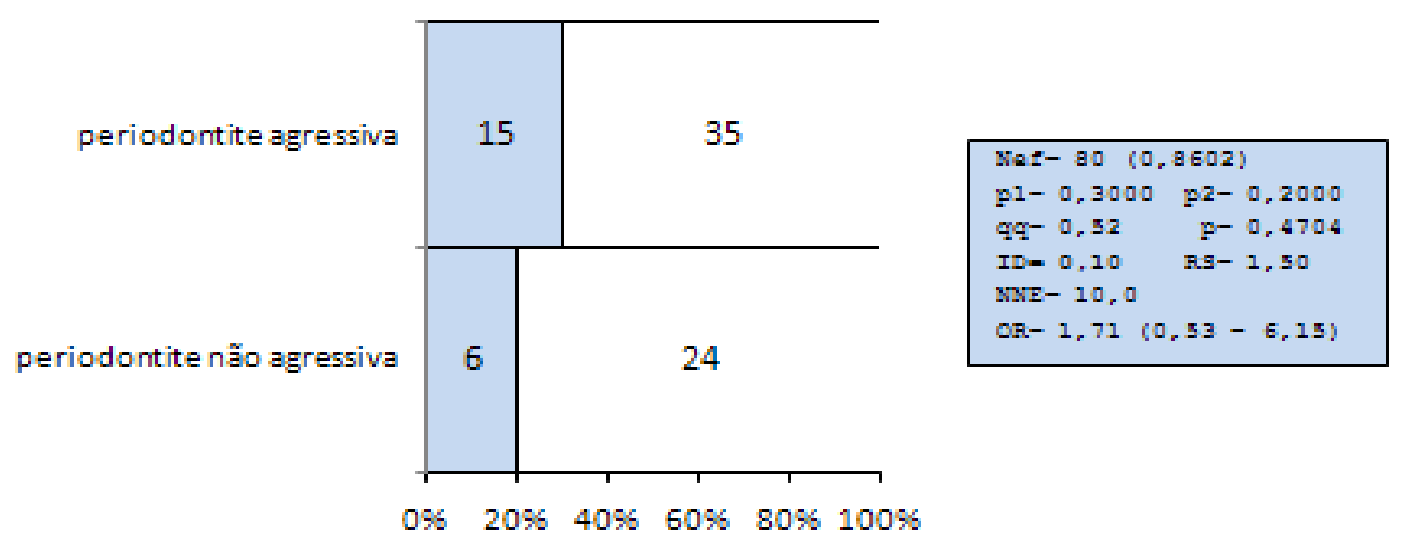

Figura 18 - Baixo peso fetal ao nascer.

$\square$ baixo peso fetal $(<2500 \mathrm{~g}) \quad \square$ peso fetal não baixo

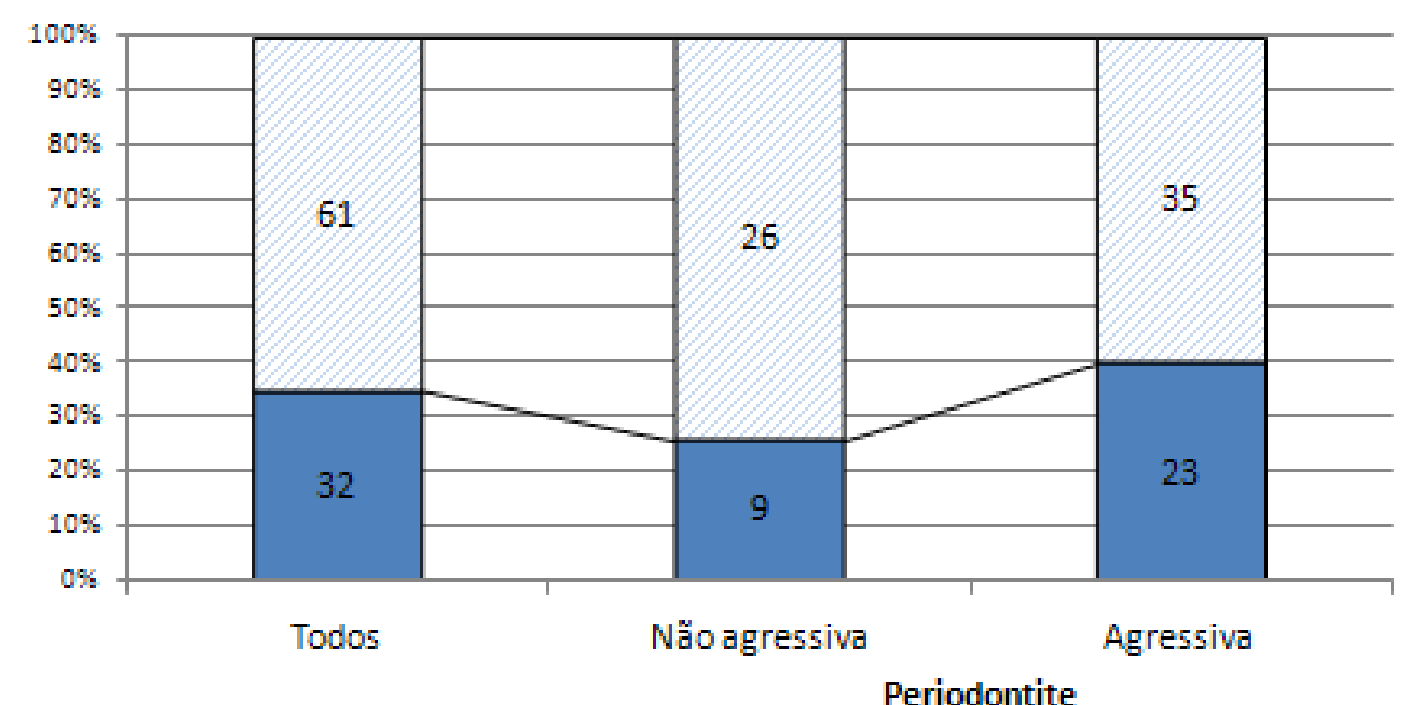

Periodontite 


\subsubsection{Bactérias periodontopatogênicas e desfechos reprodutivos ruins}

A relação entre a presença de alguma bactéria periodontopatogênica (BPPG) no âmnio com presença de corioamnionite (CAM) alcançou um contraste (ID) de quase $20 \%$, (ID=18\%, Figuras 19 e 20 ). Um forte contraste foi observado entre a bactéria periodontopatogênica P.gingivalis no âmnio e corioamnionite (ID=23\%, Figuras 21 e 22). No entanto, nenhuma destas relações foi estatisticamente significante. A prevalência de bactérias periodontopatogênica no trato vaginal na presença de rotura de membranas fetais foi de $21,74 \%$ e sem rotura das membranas foi de $25,53 \%$.

Figura 19 - Al guma (qual quer) bactéria periodontopatogênica em âmnio e corioamnionite.

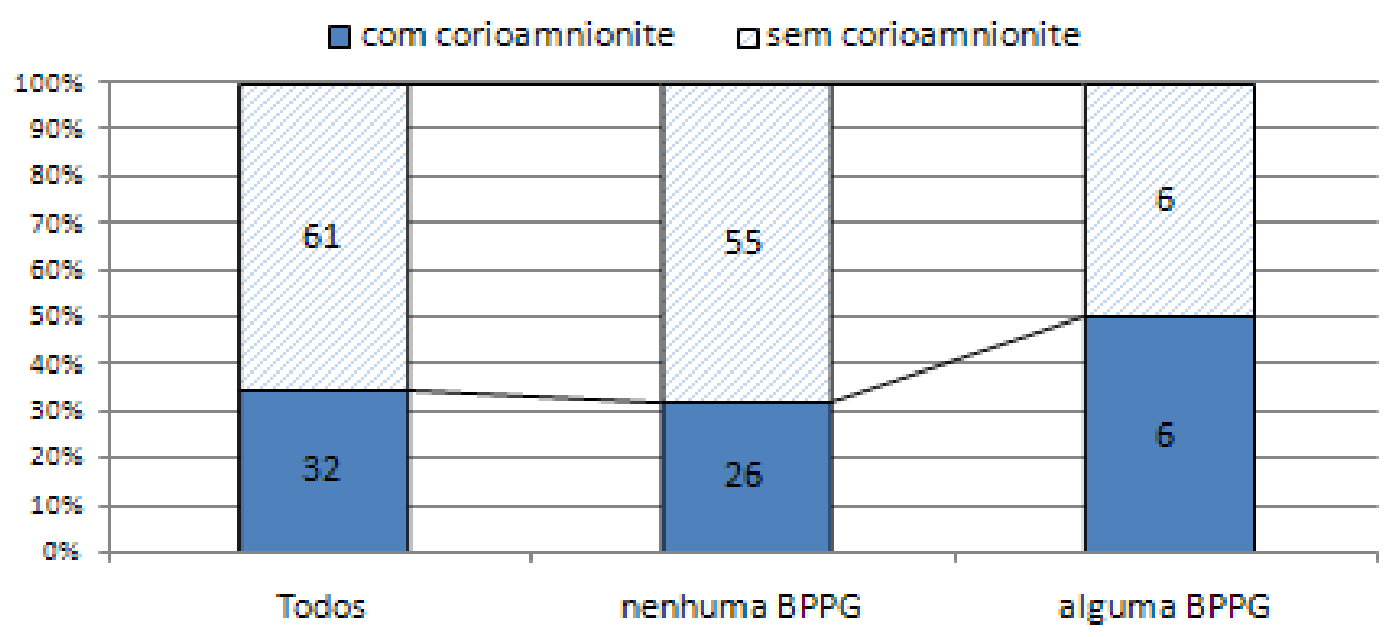


Figura 20 - Corioamnionite.

\section{$\square$ corioamnionite presente $\square$ corioamnionite ausente}

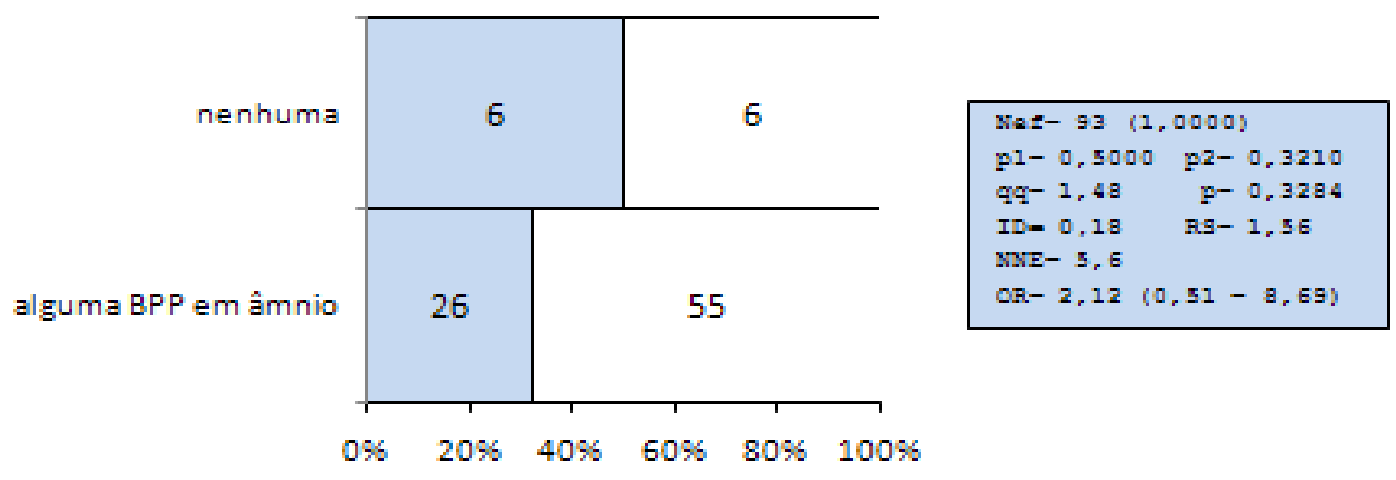

Figura 21 - P. gingivalis em âmnio e corioamnionite.

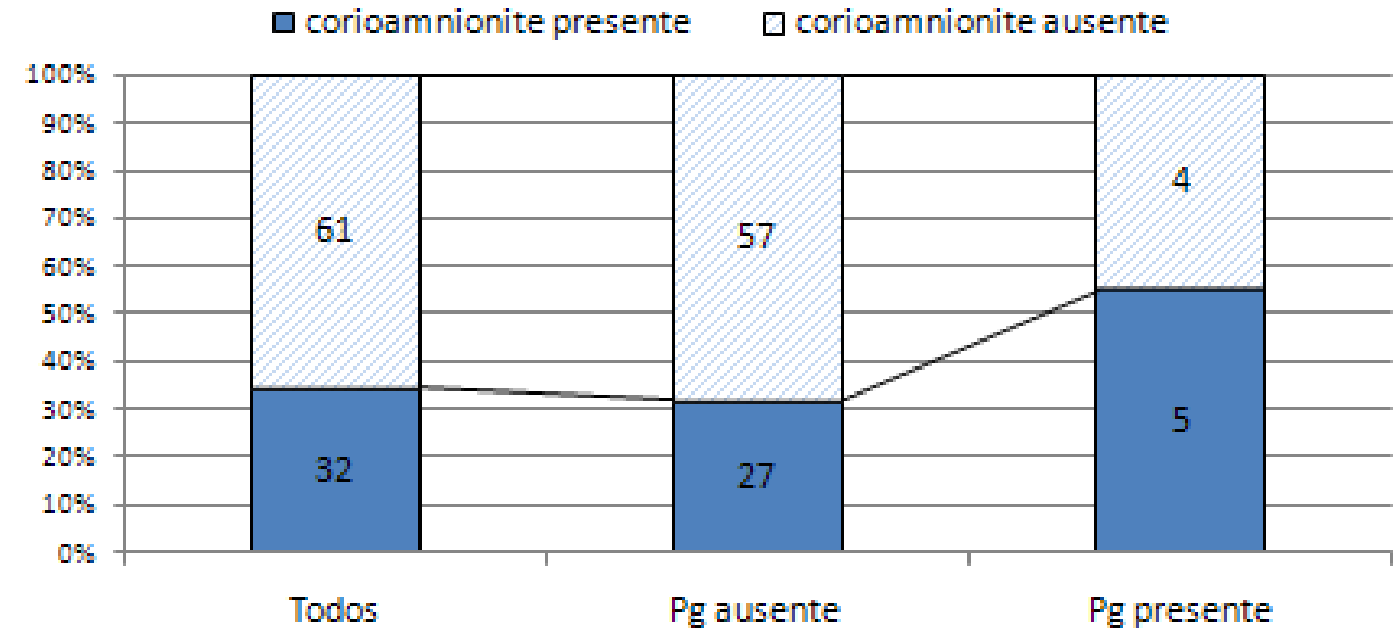


Figura 22 - P. gingivalis no âmnio e corioamnionite.

$\square$ corioamnionite presente $\square$ corioamnionite ausente

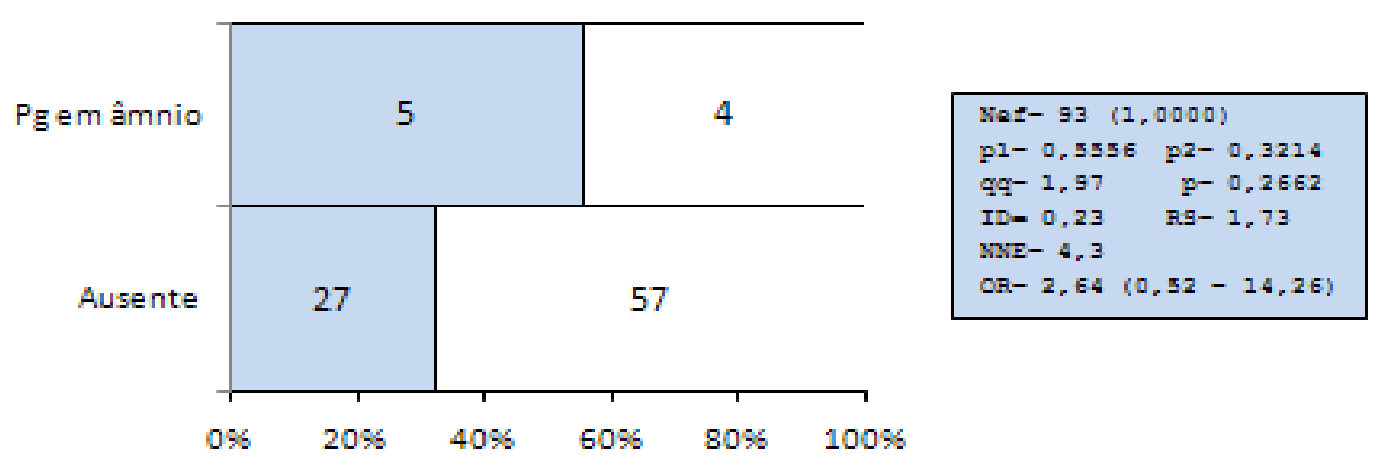




\section{DISCUSSÃO}

Os resultados do presente estudo demonstraram que, nas parturientes estudadas, os desfechos obstétricos e fetais observados são relevantes devido à conhecida relação de baixo nível sócio-econômico com doença periodontal (Bosnjak et al., 2006; Contreras et al., 2006; Cruz et al., 2005; Cruz et al., 2009; Guimarães et al., 2010; Kunnen et al., 2007; Moore et al., 2001; Ovalle et al., 2009; Vettore et al., 2008) e com desfechos reprodutivos ruins (Chan et al., 2010; Guimarães et al., 2010; Han et al., 2009; Louro et al., 2001).

Deve ser enfatizado que estas puérperas relataram nunca ter visitado um dentista durante a gestação e antes mesmo de se engravidarem. Isto, provavelmente, reflete o estado de saúde bucal encontrado nesta população. Deve ser mencionado que, em nosso modelo de estudo, além de todas puérperas serem portadoras de infecção bucal (periodontite ou gengivite), 20\% eram adolescentes (14 a 19 anos de idade).

Levando-se em consideração este resultado, Cruz et al. (2009) demonstraram que, em gestantes brasileiras, cerca de $43 \%$ eram adolescentes (13 a 20 anos) e portadoras de doença periodontal. Por sua vez, em estudos realizados por Offenbacher et al. (1996) e Jeffcoat et al. (2001), 27\% e 24\% respectivamente, das gestantes tinham menos de 20 anos e $82 \%$ da população apresentou doença periodontal, uma situação equivalente no presente estudo. Neste contexto, Ovalle et al. (2009) também confirmaram em estudo realizado no Chile com 59 gestantes, uma idade média de 26 anos, a maioria adolescente, e 99\% apresentaram infecção periodontal localizada ou generalizada. A idade na nossa população difere daquela investigada por Moore et al. (2001), os quais relataram uma idade média maior (29,8 anos) entre as gestantes, menor proporção do grupo étnico negro $(28,5 \%)$ e uma taxa de $17 \%$ de gestantes com menos de 25 anos de idade.

De maneira geral, os estudos disponíveis na literatura sobre a relação entre doença periodontal e desfechos reprodutivos ruins apontam uma maior prevalência para raça negra, semelhantemente ao encontrado no presente estudo $(75 \%)$. 
Porém, nossos resultados discrepam dos estudos de Moore et al. (2001, 2004, 2005), Noack et al. (2005) e Pitiphat et al. (2008), onde os indivíduos avaliados, predominantemente eram da raça branca.

Quanto ao nível de escolaridade, caracterizado essencialmente na amostra estudada pelo ensino fundamental, a elevada prevalência $(94,87 \%)$ observada reflete a baixa condição sócio-econômica e a natureza homogênea desta população. Muito embora, esta variável demográfica se associa com o tipo de estudo empregado, uma variabilidade entre $25 \%$ a $73 \%$ tem sido observada nesta direção (Bassani et al., 2007; Bosnjak et al., 2006; Buduneli et al., 2005; Contreras et al., 2006; Cruz et al., 2009; Kunnen et al., 2007; López et al., 2002a, 2002b; Nabet et al., 2010; Rakoto-Alson et al., 2010; Vettore et al., 2008).

É notável ressaltar que todas as gestantes fizeram o pré-natal (embora $10,84 \%$ freqüentassem menos de 6 consultas), uma clara indicação que não falta oportunidade para intervenção em saúde por culpa das pacientes. Por outro lado, López et al. (2002a) mencionam que o cuidado pré-natal inadequado age frequentemente como fator de risco para desfecho reprodutivo ruim em mulheres com baixo nível sócio-econômico e baixo nível de escolaridade. Não obstante a elevada freqüência de visitas pré-natais observada no presente estudo, mas sem significância estatística, outras pesquisas apontam concordâncias relacionadas a esta variável (Bassani et al., 2007; Bosnjak et al., 2006; Buduneli et al., 2005; Cruz et al., 2009; Offenbacher et al., 1996; Vettore et al., 2008). Outrossim, é importante mencionar que estas gestantes tinham acesso livre aos programas de cuidados prénatais oferecidos pelo HUCAM. Isto implica em melhor controle sobre os diversos fatores de risco para parto pretermo e baixo peso fetal ao nascer. Muito embora, seja aconselhável esta medida no sentido de reduzir as chances para parto pretermo, a elevada freqüência de visitas pré-natais relatada por López et al. (2002a) também não reduziu significativamente o número de partos pretermos.

Outro ponto crítico é a questão do impacto do tabagismo, um importante fator de risco para doença periodontal (Bergstrom, 1990, 2004; Bergstrom et al., 1988; Grossi et al., 1995) e desfechos reprodutivos ruins (Kierse, 1989; Shah e Bracken, 2000; Shiono et al., 1986). Em nosso estudo apenas 7,6\% de nossas 
amostras relataram que fumaram durante a gestação, mas não houve qualquer associação com doença periodontal ou com desfecho reprodutivo ruim, talvez em função deste baixo número, situação semelhante observada nos estudos de López et al. (2002a) e Moore et al. (2001). Esta baixa freqüência de tabagistas pode ser explicada devido ao registro do uso de cigarros relatado pela puérpera apenas no ato de sua matrícula para o estudo, ou seja, na internação para o parto e não durante toda a gestação ou ainda antes da gravidez. Além disso, durante suas visitas para cuidados pré-natais, recebem orientação de educação em saúde e forte aconselhamento para reduzir ou eliminar o uso de tabaco durante a gestação. Por outro lado, nos estudos de Berkowitz e Papiernik (1993) e López et al. (2002b) observaram-se associações dose-resposta entre tabagismo e baixo peso fetal, parto pretermo ou pretermo e baixo peso fetal ao nascer, com o problema peso ao nascer aumentando com o número de cigarros usados, enquanto nos estudos de Holbrook et al. (2004) e de Moore et al. (2005) foram relatados elevadas prevalências de gestantes tabagistas.

A administração de antibióticos e esteróides antes do parto são condutas médicas empregadas na gestação para redução dos prováveis desfechos reprodutivos ruins, essencialmente visando prevenir parto pretermo após ruptura prematura das membranas fetais. Muito embora apenas $12 \%$ da nossa amostra tenham sido observados infecção urinária, considerada fator de risco obstétrico importantíssimo para parto pretermo, isto pode ser reflexo do diagnóstico de infecção genito-urinária materna devido à infecção subclínica presente ou ainda a administração de antibióticos no último mês da gestação para previnir infecção ascendente na época do parto. No entanto, esta discrepância divergiu do relato de Offenbacher et al. (1996), onde $25 \%$ da amostra apresentou esta infecção, enquanto que Moore et al. (2005) encontraram 39\% na sua população, mas bem menos que, os $15 \%$ observados por Moore et al. (2001) para as gestantes primíparas com parto extremo pretermo e os $5 \%$ observados nas gestantes com parto a termo no estudo de Bosnjak et al. (2006).

A hipertensão arterial nas gestantes neste estudo transversal caracterizou-se por baixa prevalência (11\%). Este aspecto não tem sido diferente em alguns estudos (Bassani et al., 2007; Davenport et al., 2002; Guimarães et al., 2010 
Louro et al., 2001; Moliterno et al., 2005; Vettore et al., 2008), os quais, também, relataram nenhuma associação significante com doença periodontal ou com outros fatores obstétricos. Já o estudo de Nabet et al. (2010) realizado em maternidades francesas, uma associação significante foi observada entre periodontite generalizada e parto pretermo induzido para pré-eclâmpsia. Outro estudo (Kunnen et al.,2007) também demonstrou uma associação significante entre gestantes com préeclâmpsia e doença periodontal severa, mesmo com uma amostra pequena $(n=52)$.

O efeito de doenças ou condições sistêmicas sobre o estado de saúde ou doença do periodonto tem sido amplamente reconhecido. Por outro lado, estudos sobre efeito da doença periodontal sobre doenças ou condições sistêmicas são, relativamente, mais recentes. Esses estudos sugerem leves a moderadas associações entre doença periodontal e certas desordens sistêmicas, entre as quais, diabetes melitus (Offenbacher et al., 1996). Na amostra estudada, apenas $4,4 \%$ das puérperas apresentou diabetes melitus, resultado semelhante observado em outras investigações (Guimarães et al., 2010; López et al., 2002b; Moliterno et al., 2005; Vettore et al., 2008).

Quanto à via do parto, a elevada prevalência (em torno de 66\%) de parto cesariano na nossa amostra demonstra que, as gestantes do sistema único de saúde buscam este hospital público terciário, HUCAM, para serem assistidas em gestações de alto risco, especificamente para partos pretermos. Este aspecto obstétrico observado na nossa amostra está de acordo com os trabalhos de Vettore et al. (2008) e Han et al. (2009) que demonstraram uma maior prevalência de partos cesarianos em gestantes com partos pretermos ou partos com baixo peso fetal ao nascer, mas difere dos resultados de Rakoto-Alson et al. (2010) e Buduneli et al. (2005), onde esta via apresentou baixa freqüência.

A ruptura das membranas fetais ao termo é uma parte normal do processo de parturição que ocorre após o início das contrações uterinas. Entretanto, o nascimento prematuro é a principal causa de mortalidade e morbidade neonatal no mundo (Digiulio et al., 2008; Mass et al., 1999; Menon e Fortunato, 2007; Romero et al., 2006). A ruptura prematura das membranas fetais (PROM/PPROM) e o trabalho de parto pretermo são frequentemente associadas com parto pretermo. A ruptura 
prematura e precoce das membranas fetais (PPROM) está associada com 30 a 40\% dos partos pretermos e é a principal causa identificável de parto pretermo (Menon e Fortunato, 2007). Em nosso estudo, a prevalência da rotura de membranas fetais (PPROM/PROM) acima de 12 horas atingiu cerca de 18\% das puérperas, bem próximo dos resultados de Ovalle et al. (2009) com freqüência de 28\% (17/59). No entanto, León et al. (2007) encontraram cinco gestantes $(41,66 \%)$ das 12 com periodontite portadoras de PPROM, enquanto três gestantes das oito com gengivite apresentaram PPROM, mas sem significância estatística.

Em outro estudo, Jarjoura et al. (2005) demonstraram que 55,4\% (46/83) das gestantes (idade gestacional média de 33,2 semanas) com partos pretermos apresentaram PPROM, enquanto nas gestantes com partos a termo (idade gestacional de 39,3 semanas), 19,2\% (23/120) também tiveram PPROM e esta associação se mostrou estatisticamente significante. Por sua vez, Nabet et al. (2010) também não observaram relação significante entre periodontite localizada e generalizada com PPROM ou parto pretermo espontâneo. Estes aspectos são relevantes do ponto de vista inflamação/infecção, porque, aproximadamente em $30 \%$ dos casos com PROM, o isolamento bacteriano não se correlaciona com alterações inflamatórias encontradas durante a corioamnionite histológica (CAM). No presente estudo, a CAM observada nas puérperas foi de 34,4\%, uma taxa relativamente elevada e próxima aos 38,40\% relatados por Merçon-De-Vargas (1992), ambos os estudos de corte transversal do II trimestre, na mesma instituição. Esta grande prevalência pode ser atribuída, entre outros fatores, à população crescente de pacientes de alto risco obstétrico atendidas na instituição. A prevalência de CAM em estudos de doença periodontal variou de $2 \%$ a $38 \%$ (Han et al., 2006; Leon et al., 2007; Louro et al., 2001; Offenbacher et al., 2001).

Deve ser mencionado que, quando a infecção está limitada ao espaço amniocoriônico ou à decídua (inflamação localizada confinada ao coriodecídua), o processo inflamatório é detectado nas membranas e é de origem materna. No estágio final, no qual há invasão do feto pelos microrganismos, freqüentemente promove uma resposta inflamatória fetal (corioamnionite histológica com funisite), porém estas lesões também podem ocorrer em resposta ao estímulo quimiotático presente na cavidade amniótica, sem invasão microbiana do feto (Park et al., 2009). 
As nossas taxas observadas para nascimento pretermo $(<34$ semanas $\mathrm{e}<37$ semanas) e baixo peso fetal ao nascer $(<2500 \mathrm{~g})$ foram respectivamente, $22,58 \%$, $36,56 \%$ e $34,4 \%$, prevalências maiores que relatadas em alguns estudos (Bosnjak et al., 2006; Hoolbrook et al., 2004; Louro et al., 2001; Offenbacher et al., 2009; Ryu et al., 2010). Embora, alguns estudos incluindo apenas partos pretermos mostrem resultados conflitantes (Michalowicz e Durand, 2007; Santos-Pereira et al., 2007), nossos resultados estão de acordo com alguns estudos europeus (Michalowicz e Durand, 2007; Moore et al., 2005; Nabet et al., 2010).

Apenas $8,6 \%$ das puérperas no presente estudo apresentou vilosite, bem menos do que observado por Ovalle et al. (2009). A atribuição deste desfecho reprodutivo é tema controverso e inclui a morte perinatal (Altshuler, 1997; Benirschke et al., 2006; Fox, 1978; Fox e Sebire, 2007; Kloos e Vogel, 1978).

Morte perinatal (natimorto) é um tipo de desfecho reprodutivo que não tem sido comumente relatado em estudos que investigam doença periodontal e desfechos reprodutivos ruins. Em geral, os estudos publicados têm avaliado o efeito da terapia periodontal sobre tais desfechos reprodutivos variando entre dois a oito natimortos e/ou abortos espontâneos (Jeffcoat et al., 2003; López et al., 2002b; López et al., 2005; Michalowicz et al., 2006;; Tarannum e Faizuddin, 2007). Na amostra estudada foram observadas cinco mortes perinatais (natimorto), ou seja, 5,38\%, concordando com os estudos acima citados. Contudo, no estudo de Moore et al. (2004) se observou uma taxa total de 18,9\% (natimorto e/ou aborto espontâneo), sendo que $21,2 \%$ das mortes perinatais foram encontradas em gestantes com periodontite severa e $17,3 \%$ em gestantes periodontalmente sadias.

A doença periodontal é tradicionalmente definida baseada nos fatores de morbidade clínica ao redor do dente, ou seja, profundidade de sondagem ou bolsa, perda do nível de inserção e perda óssea radiográfica. Contudo, não há consenso sobre o que constitui limite para doença periodontal (Chan et al., 2010). Assim, o critério de infecção periodontal adotado neste estudo ( $P B \geq 4,0 \mathrm{~mm}$ e $\mathrm{NCl} \geq 3,0 \mathrm{~mm}$ ) tem sido amplamente utilizado em estudos de periodontite relacionados com desfechos reprodutivos ruins (Buduneli et al., 2005; Cruz et al., 2009; Jarjoura et al., 2005; Lieff et al., 2004; López et al. 2002a; Moliterno et al., 2005; Moss et al., 2005; Noack et al., 2005), muito embora ocorra variabilidade na definição da doença. $\mathrm{Na}$ 
nossa amostra, como todo, encontramos uma alta prevalência $(93,05 \%)$ de periodontite, mas não tão discrepante de outros estudos (Offenbacher et al., 1996, Vettore et al., 2008). Vale ainda mencionar que na amostra, tivemos mais puérperas com periodontite agressiva (62,03\%) do que com periodontite crônica (32,02\%), com destaque para alta prevalência nas extensões localizadas e generalizadas da periodontite agressiva, semelhante ao estudo de Ovalle et al. (2009), mas diferente de Nabet et al. (2010) que encontraram uma taxa de 10,8\% para ambas as formas da doença periodontal.

As puérperas matriculadas no presente estudo e caracterizadas por uma população homogeneamente de baixa renda, a vasta maioria nunca tinha visitado um dentista. Esta situação sugere que o estado da doença periodontal nesta população possa ser considerado mais nativo. Este estudo compreendeu uma população bem definida com mulheres dando partos em um hospital público terciário, com alta experiência de cárie $(83,87 \%$ e $72,04 \%$, respectivamente) e hábitos de higiene oral (47\% de placa dental) distantes do nível satisfatório, porém, compatíveis com vários estudos (Bassani et al., 2007; Budunelli et al.,2005; Jarjoura et al. ,2005; Lieff et al., 2004; Moore et al., 2004; Moore et al., 2005; Nabet et al., 2010; Vettore et al., 2008), mas discordantes com outros (Contreras et al., 2006; Rakoto-Alson et al., 2010).

Quanto ao risco de doença periodontal definido no estudo pela profundidade de bolsa (PB), perda do nível clínico de inserção ( $\mathrm{NCl})$ e sangramento à sondagem (SS), verifica-se que apesar da baixa porcentagem de sítios (22,6\%) com sangramento gengival (um indicador clínico de doença ativa), 50\% da amostra apresentam médias elevadas para $\mathrm{PB}$ e $\mathrm{NCl}$, ou seja, 4,6 mm e 3,8 mm, respectivamente, semelhante aos relatados em alguns estudos (Bosnjak et al., 2006; Buduneli et al., 2005; Contreras et al., 2006; Ryu et al., 2010). Entretanto, nossas médias diferem de outras investigações (Jarjoura et al., 2005; López et al., 2002a Moliterno et al., 2005; Moore et al., 2001; Moore et al., 2004; Moore et al., 2005; Noack et al., 2005; Offenbacher et al., 1996; Offenbacher et al., 2009; Rakoto-Alson et al., 2010; Santos-Pereira et al., 2007; Vettore et al., 2008), os quais observaram variabilidade de 1,33 $\mathrm{mm}$ a 3,5 $\mathrm{mm}$ para $\mathrm{PB}$ e de 0,21 $\mathrm{mm}$ a 2,75 $\mathrm{mm}$ para $\mathrm{NCl}$ em puérperas com partos pretermos. Este padrão médio de bolsas periodontais e perda 
de inserção certamente identificam uma puérpera com risco de progressão, apesar de não termos avaliado esta condição clínica no início da gestação.

Também foram observadas todas as bactérias periodontopatogênicas (BPPG) em ambas, boca e vagina, $P$. gingivalis e $F$. nucleatum no âmnio, além de $P$. gingivalis, $F$. nucleatum e T. forsythia no parênquima placentário. Duas destas bactérias ( $F n$ e $P g$ ) pertencentes ao complexo vermelho descrito por Socransky et al. (1998) tem sido encontradas na vagina (Bearfield et al., 2002; Hill, 1993; Persson et al., 2009), no âmnio (Hill, 1993, 1998; León et al., 2007) e na placenta em puérperas com desfechos reprodutivos ruins (Barak et al., 2007, Bearfield et al., 2002; Han et al., 2006).

A elevada prevalência de $P$. gingivalis e $T$. forsythia observada no biofilme subgengival está de acordo com outros relatos (Hasegawa-Nakamura et al., 2003; León et al., 2007; Ovalle et al., 2009), mas a prevalência de $A$. actinomycetemcomitans e $F$. nucleatum mostrou-se abaixo do esperado (Léon et al., 2007, Madianos et al., 2001; Ovalle et al., 2009).

As bactérias periodontopatogênicas foram observadas nas amostras vaginais, com $P$. gingivalis sendo o mais freqüente deles. A prevalência observada de cada periodontopatógeno na vagina variou de $3,23 \%$ para $A$. actinomycetemcomitans, $17,20 \%$ para $P$. gingivalis, ambos valores menores do que a maioria dos resultados relatados (Bearfield et al., 2002; Hillier et al., 1995; Persson et al., 2009).

Fusobacterium nucleatum uma bactéria anaeróbica Gram-negativa, membro da microbiota indígena da cavidade bucal e comumente isolado de infecções bucais (Avila-Campos et al., 1999a) é uma bactéria raramente encontrada no trato vaginal, mas tem sido encontrada em elevado número no líquido amniótico (Hill, 1993). A maioria das investigações tem sido realizada em pacientes selecionadas (majoritariamente em partos pretermos) o que tornou difícil a comparação dos nossos resultados com aqueles da literatura.

Apenas $F$. nucleatum (4,30\%) e $P$. gingivalis $(13,97 \%)$ foram detectadas nas amostras amnióticas, constituídos como os mais freqüêntes ou únicas bactérias 
descritas no líquido amniótico de mulheres com trabalho de parto pretermo assistido (Bearfield et al., 2002; Hill, 1993; Ovalle et al., 2009). A baixa prevalência observada neste estudo pode ser explicada devido ao desenho deste trabalho (corte transversal) e pela elevada proporção de partos a termo. Assim, a possibilidade de contaminação do âmnio através da vagina foi excluída porque em nenhuma das infecções amnióticas houve a mesma bactéria encontrada na vagina.

A prevalência de $P$. gingivalis e $F$. nucleatum no parênquima placentário foi muito menor do que os $19,04 \%$ de $F$. nucleatum (Han et al., 2009) e os $30 \%$ de $P$. gingivalis (Barak et al., 2007) descritos em parto pretermo ou gestação de alto risco Hasegawa-Nakamura et al., 2011; Madianos et al., 2001; Vettore et al., 2008). A detecção de $T$. forsythia no parênquima placentário não tem sido, em geral, freqüentemente relatada nos estudos.

A cavidade bucal é a mais importante fonte das quatro bactérias periodontopatogênicas analisadas neste estudo, mas não a única fonte como tem sido relatada em outros sítios corporais, particularmanente no trato vaginal, entre eles: A. actinomycetemcomitans (Persson et al., 2009), F. nucleatum (Bearfield et al., 2002, Hill, 1993; Persson et al., 2009), P. gingivalis (Persson et al., 2009) e $T$. forsythia (Persson et al., 2009). Isto mostra a falta de conhecimento sobre o real significado da detecção destas bactérias em ambientes extraorais, provavelmente constituindo-se como microbiota transitória com capacidade de permanência em ecossistemas diferentes. Deste modo, para todos os propósitos, a cavidade bucal deve ser considerada a fonte primária e a mais importante na transmissão desses microrganismos.

A despeito da detecção de todas as BPPG nas amostras vaginais, houve apenas uma única deteç̧ão simultânea boca-vagina de $P$. gingivalis com uma taxa de disseminação de 20,0\% (6/30). De acordo com outros estudos (León et al., 2007; Ovalle et al., 2009), a cavidade bucal materna não parecer ser a fonte de transmissão e disseminação microbiana na maioria das infecções vaginais, devido às evidências de uma resposta protetora de anticorpos maternos para bactérias periodontais reduzindo a colonização (Madianos et al. 2001). 
Como a via hematogênica proposta por Kornman e Loesche (1980) é implausível, outras vias pelas quais as BPPG poderiam acessar o trato vaginal devem ser consideradas. Ao lado das fontes e vias externas indiretas como cães e gatos, está a microbiota fecal ou a cavidade bucal do parceiro sexual. Como neste estudo não foram examinadas amostras fecais, essa fonte não pode ser excluída. Pelos resultados obtidos neste estudo, é possível sugerir que a transmissão bacteriana pode ser realizada, talvez, pela prática sexual oro-genital. Santos (2009) em estudo realizado com 18 mulheres sexualmente ativas e acompanhadas por meio de um diário de prática sexual observou que a vagina era exposta à saliva em $79,6 \%$ das sessões sexuais.

Neste estudo, foi notado que $A$. actinomycetemcomitans, $F$. nucleatum e $P$. gingivalis encontrados nas infecções vaginais não foram observadas no âmnio, provando-se que não houve disseminação bacteriana para esse local. Assim, a presença de $F$. nucleatum e $P$. gingivalis nas infecções amnióticas deve ser mais profundamente investigada. Outra possibilidade de que a bactéria oral presente na vagina fosse removida pela passagem do líquido amniótico também foi excluída porque a prevalência bacteriana no trato vaginal foi similar nos casos com $(21,74 \%)$ ou sem (25,53\%) rupturas de membranas. Hill (1993) relatou a elevada prevalência de $P$. gingivalis no âmnio relacionando com a sua presença no trato vaginal.

Segundo Han et al. (2006), é possível que uma infecção vaginal transitória e localmente limitada tenha ocorrido, disseminada através da cérvice vaginal para as membranas fetais e subseqüentemente desaparecido na vagina pelas caracaterísticas ambientais desse ecossistema. Também, outra explicação para a ausência de infecções amnióticas nas infecções vaginais observadas neste estudo, está de acordo com a descrição clássica da patogênese da infecção amniótica mencionada por Blanc (1961), onde bactérias presentes na vagina ascendem da cérvice para as membranas fetais, causando infecção e disseminando para o líquido amniótico. A corioamnionite realmente não exige a presença da bactéria no âmnio, mas apenas as substâncias quimiotáticas produzidas pelas bactérias no líquido amniótico. Em nosso estudo foi observada uma estreita relação de contraste de $18 \%$ entre a presença das bactérias periodontais no âmnio e a corioamnionite, além de um forte contraste de $23 \%$ entre $P$. gingivalis no âmnio e CAM, concordando com 
outros estudos (Han et al., 2009; Jarjoura et al., 2005; Katz et al., 2009; León et al., 2007; Ovalle et al.,2009).

Da mesma forma, outros estudos apontam diferentes patógenos periodontais relacionados com CAM, tais como, Bergeyella sp. (Han et al., 2006), Eikenella corrodens (Jadhav et al., 2009) e F.nucleatum (Han et al., 2010). Mesmo diante disso, este contraste não se associou com maior freqüencia ou risco de PROM/PPROM, PPT, BPN, MPN ou com DRR (PPT ou BPN ou MPN), apesar da elevada incidência de corioamnionite histológica $(34,4 \%)$ observada nas puérperas avaliada neste presente estudo. No entanto, Hasegawa-Nakamura et al. (2011) demonstraram uma prevalência bacteriana mais densa no líquido amniótico do que nas membranas amnióticas.

Nossos resultados não excluem a etiologia infecciosa para os 36,56\% de PPT, que podem ter sido determinadas por infecção vaginal, cervical, endometrial, da cavidade amniótica ou do parênquima da placenta, nestes dois últimos, nas gestantes estudadas, sem inflamação diagnosticável pela histopatologia. Mas como nos recordam Kramer (2003) e Haram et al. (2003), que infecções do trato genital e amniótico são responsáveis não por todos, mas por 25 a 75\% dos casos de PPT e também que mais de um fator causal está operando nas mulheres mais propensas à doença periodontal e desfecho reprodutivo ruim.

A ausência de CAM nos casos com BPPG no âmnio pode ser atribuída a quatro razões: (1) Limitada capacidade das BPPG de penetrar e proliferar nas membranas fetais e/ou quimiotactismo fraca, características que são variáveis de microrganismo para microrganismo; (2) Trata-se de infecção de curta duração ou lenta, não completamente desenvolvida pela interrupção do processo devido à ultimação do parto, portanto com pouco exsudato inflamatório como se descreve para o S. agalactiae (Altshuler, 1997; Benirschke et al., 2006). Uma inflamação distribuída difusamente em toda a superfície das membranas é observada em aproximadamente 12 a 48 horas após a infecção, tempo requerido para a penetração e proliferação microbiana (Blanc, 1961; Tolockiene et al., 2001); (3) Erro ao amostrar as membranas extra-placentárias (deixando de incluir as bordas de rotura no fragmento) ou das membranas placentárias (escolha de locais com 
trombose subcorial, talvez o erro mais comum em patologia placentária); (4) Erro de observação microscópica, deixando de identificar a inflamação, por inexperiência ou distração, esta uma importante causa de erro diagnóstico em patologia. Este é um aspecto importante que explica por que não há inflamação e, portanto, porque não há desfecho ruim como mostram a ausência de contraste significativo deste tanto com a mera presença como com a ausência ou com uma discreta inflamação. $O$ ponto relevante aqui é que nós temos examinado as membranas amnióticas e não o líquido amniótico, e, então, pode ser que tenhamos perdido alguns casos de infecções amnióticas.

Apenas um dos quatro P.gingivalis, nenhum dos F. nucleatum e T. forsythia nas puérperas positivas para parênquima placentário parece vir da cavidade bucal materna, das fontes vaginal ou amniótica, um achado também verificado por outros (Barak et al., 2007; Hasegawa-Nakamura et al., 2011; Katz et al., 2007). A raridade de detecção simultânea na cavidade bucal materna nos casos de infecção do parênquima placentário torna difícil de explicar a fonte da bactéria. HasegawaNakamura et al. (2011), por exemplo, detectaram $P$. gingivalis na cavidade bucal de três dos seis casos positivos para parênquima placentário e não puderam excluir a fonte vaginal ou cervical.

Os resultados do presente estudo são intrigantes e imprevistos. As puérperas têm uma alta prevalência de periodontite agressiva e desfechos perinatais ruins. Neste estudo foi detectado um número significante de infecções periodontais, vaginais, amnióticas e placentárias produzidas por BPPG, mas a cavidade bucal materna não parece ser a fonte da maioria das infecções, assim como nenhuma das infecções amnióticas observadas pareceram ser originadas do trato vaginal.

Assim como em muitos casos, a fonte de BPPG na vagina, membrana amniótica e parênquima placentário pode não ser a cavidade bucal materna, de onde elas vêm? Com isso, podem-se sugerir algumas hipóteses:

1) Todas as infecções vaginais, amnióticas e do parênquima placentário vem da cavidade bucal materna, mas no momento de coleta da amostra, a carga bacteriana periodontal estava tão baixa ou localmente restrita que não pode 
ser detectada pelo método do PCR, ou seja, a prevalência observada neste estudo foi subestimada. Por outro lado, não está claro porque a bactéria pode ter disseminado em alguns casos e não em outros. Entretanto, em condições anormais, tais como, pobre higiene oral e doença periodontal agressiva, a carga bacteriana no biofilme supragengival, aumenta de duas a 10 vezes mais, e assim há maior possibilidade de introduz mais bactérias dentro da corrente sanguínea, elevando a prevalência e magnitude da bacteriemia (Lopatin et al., 1980), mas isto, também não explica a baixa proporção da infecção vaginal observada;

2) As bactérias vêm de outros sítios corporais, uma possibilidade sugerida, mas não confirmada neste e nem outros estudos (Bearfield et al., 2002; Ovalle et al., 2009). A mais provável fonte é a contaminação fecal, assim como esta é a fonte de alguns microrganismos mais freqüentemente identificados nas infecções vaginais e amnióticas;

3) As infecções vaginais e amnióticas viriam de microrganismos da cavidade bucal do parceiro sexual materno, como sugerido por Hill (1993), uma hipótese plausível, mas não confirmada pelos estudos já realizados. Entretanto, essas fontes merecem destaques por causa da presença ubíqua da BPPG e da freqüência das práticas sexuais oro-genitais. Em outras palavras, o perigo real vem da periodontite do parceiro sexual e dessas práticas sexuais.

Para confirmar a disseminação de um sítio para outro é necessário demonstrar não apenas sua presença em ambos os sítios, mas também demonstrar que a cepa bacteriana é a mesma por meio de técnicas moleculares (Han et al., 2006). Entretanto, a presença da mesma bactéria na cavidade bucal e no âmnio ou no líquido amniótico tem sido considerada uma evidência de que os microrganismos bucais teriam sua origem na cavidade bucal (Chaim e Mazor, 1992; Hill, 1998).

Outros estudos têm sugerido que a via hematogênica permite a disseminação de bactérias periodontais para o líquido amniótico (Han et al., 2010; Hill, 1998; Offenbacher et al., 1998), mas isso não é uma evidência empírica nem biologicamente plausível. Nossos resultados revelam a elevada prevalência desses organismos no trato vaginal e no âmnio, à diferença daquilo observado no 
parênquima placentário, o que sugeriria a existência de uma via de disseminação transcervical (corioamnionite) podendo ser considerada de maior importância que a via hematogênica transplacentária (vilosite).

Finalmente, os resultados aqui mostrados sugerem a necessidade de se realizar maiores estudos inluindo os parceiros sexuais para definir melhor a origem desses microrganismos que com alguma frequência podem produzir essas infecções em puérperas. 


\section{CONCLUSÕES}

Os resultados do presente estudo permitem concluir que:

1 - Foi observada elevada prevalência de doença periodontal, corioamnionite e de todos os desfechos reprodutivos ruins nas pacientes analisadas, porém doença periodontal não se associou com maior freqüência ou maior risco de corioamnionite nem de nenhum dos desfechos reprodutivos estudados nestas puérperas;

2 - As bactérias periodontais atingem a vagina e o âmnio placentário, indicando que podem ser responsáveis pela infecção amniótica e do feto, embora, a sua presença em qualquer sítio, mesmo no âmnio placentário não se associou com maior freqüência ou risco de corioamnionite nem de desfecho reprodutivo ruim nestas puérperas;

3 - Bactérias periodontais podem atingir o parênquima da placenta, mas não se associou com a vilosite. 


\section{REFERÊNCIAS}

Adriaens LM, Alessandri R, Sporri S, Lang NP, Persson GR. Does pregnancy have an impact on the subgingival microbiota. J Periodontol. 2009; 80:72-81.

Agueda A, Ramón JM, Manau C, Guerrero A, Echeverría J.J. Periodontal Disease as a Risk Factor for Adverse Pregnancy Outcomes: A Prospective Cohort Study. J Clin Periodontol. 2008; 35:16-22.

Ainamo J, Bay I. Problems and proposals for recording gingivitis and plaque. Int Dent J.1975; 25:229-35.

Althabe O, Schwarcz R. Aspectos perinatales del parto prematuro. Buenos Aires: El Ateneo; 1978. $128 \mathrm{p}$.

Altshuler G. Pathology of the Placenta. In: Gilbert-Barnes, editors. Potter's Pathology of the Fetus and the Newborn Infant. chap.8, St Louis: Mosby; 1997. 259p.

Altshuler G, Hyde S. Fusobacteria. An important cause of chorioamnionitis. Arch Pathol Lab Med. 1985; 109:739-43.

Alves RT, Ribeiro RA. Relationship between maternal periodontal disease and birth of preterm low weight babies. Braz. Oral Res. 2006; 20:318-23.

Amano A, Nakagawa I, Ataoka K, Morisaki I, Hamada S. Distribution of Porphyromonas gingivalis strains with fimA genotypes in periodontitis patients. J Clin Microbiol. 1999; 37:1426-430.

Armitage G. Development of a Classification System for Periodontal Diseases and Conditions. Ann Periodontol.1999; 4:1-6.

Armitage G. Periodontal Diagnoses and Classification of Periodontal Diseases. Periodontol 2000. 2004; 34:9-21.

Ashimoto A, Chen C, Bakker I, Slots J. Polymerase chain reaction of 8 putative periodontal pathogens in subgingival plaque of gingivitis and advanced periodontitis. Oral Microbiol Immunol. 1996; 11:66-73. 
Avila-Campos MJ, Sacchi CT, Whitney AM, Steigerwalt AG, Mayer LW. Arbitrarily primed-polymerase chain reaction for identification and epidemiologic subtyping of oral isolates of Fusobacterium nucleatum. J Periodontol. 1999a; 70:1202-1208.

Avila-Campos MJ, Sacchi CT, Whitney AM, Steigerwalt AG, Mayer LW. Specific primer design using AP-PCR for identification of Actinobacillus actinomycetemcomitans. J Clin Periodontol. 1999b; 26:699-74.

Barak S, Barak OO, Machtei EE, Sprecher H, Ohel G. Evidence of periodontopathogenic microorganisms in placentas of women with pré-eclâmpsia. $\mathrm{J}$ Periodontol. 2007; 78:670-676.

Bassani DG, Olinto MTA, Kreiger N. Periodontal disease and perinatal outcomes: a case-control study. J Clin Periodontol. 2007; 34:31-39.

Bearfield C, Davenport ES, Sivapathasundaram V, Allaker RP. Possible association between amniotic fluid micro-organism infection and microflora in the mouth. $\mathrm{Br} \mathrm{J}$ Obstet Gynaecol.2002; 109:527-33.

Benirschke K, Kaufmann P, Baergen R. The pathology of the human placenta. 5rd ed. New York: Springer-Verlag; 2006.

Bergstrom J, Persson L, Preber $\mathrm{H}$. Influence of cigarette smoking on vascular reaction during experimental gingivitis. Scand J Dent Res. 1988; 96:34-39.

Bergstrom J. Oral hygiene compliance and gingivitis expression in cigarette smokers. Scand J dent Res. 1990; 98:497-503.

Bergstrom J. Tobacco smoking and chronic destructive periodontal disease. Odontol. 2004; 92:1-8.

Berkowitz GS, Papiernik E. Epidemiology of Preterm Birth. Epidemiol Rev. 1999; 15:414-43.

Blanc WA. Amniotic infection syndrome: pathogenesis, morphology, and significance in circumnatal mortality. Clin Obstet Gynecol.1959; 2:705-734.

Blanc WA. Pathways of fetal and early neonatal infection. Viral placentitis, bacterial and fungal chorioamnionitis. J Pediatr. 1961; 59:473-496. 
Bobetsis YA, Barros SP, Offenbacher S. Exploring the relationship between periodontal disease and pregnancy complications. J Am Dent Assoc. 2006; 137 Suppl10: S7-13.

Bosnjak A, Relja T, Vucicevic-Boras V, Plasaj H, Plancak D. Pre-term delivery and periodontal disease: a case-control study from Croatia. J Clin Periodontol. 2006; 33:710-16.

Brunetti MC. A infecção periodontal associada ao parto pré-termo e baixo peso ao nascer. 2002. Tese (Doutorado em Saúde Pública) - Faculdade de Saúde Pública, Universidade de São Paulo, São Paulo; 2002.

Buduneli N, Baylas H, Buduneli E, Turkoglu O, Kose T, Dahlen G. Periodontal infections and preterm low birth weight: a case-control study. J. Clin. Periodontol. $2005 ; 32: 174-81$.

Calabrich CFC, Calabrich JLS. A Infecção periodontal durante a gravidez. Fem. 2005; 33:609-12.

Chan HC, Wu CT, Welch KB, Loesche WJ. Periodontal disease activity measured by the Benzoyl-DL-Arginine-Naphthylamide Test is associated with preterm births. $J$ Periodontol. 2010; 81:982-91.

Chaim W, Mazor M. Intrammniotic infection with fusobacteria. Arch Gynecol Obstet.1992; 251:1-7.

Chaim W, Mazor M, Leiberman JR. The relationship between bacterial vaginosis and preterm birth. A review. Arch Gynecol Obstet. 1997; 259:51-8.

Clothier B, Stringer M, Jeffcoat MK. Periodontal disease and pregnancy outcomes: exposure, risk and intervention. Best Pract Res Obstet Gynaecol. 2007; 21:451-66.

Contreras AA, Herrera JA, Soto JE, Arce RM, Jaramillo A, Botero JE. Periodontitis is associated with preeclampsia in pregnant women. J Periodontol. 2006; 77:182-88.

Cruz SS, Costa MCN, Gomes Filho IS, Vianna MIP, Santos CT. Doença periodontal materna como fator associado ao baixo peso ao nascer. Rev Saúde Pública. 2005; 39:782-87.

Cruz SS, Costa MCN, Gomes-Filho IS, Rezende EJC, Barreto ML, Santos CAST, Vianna MIP, Passos JS, Cerqueira EMM. Contribution of periodontal disease in 
pregnant women as a risk factor for low birth weight. Community Dent Oral Epidemiol. 2009; 37:527-33.

Davenport ES, Williams CECS, Sterne JAC, Murad S, Sivapathasundram V, Curtis MA. Maternal periodontal disease and preterm low birthweight: case-control study. J Dent Res. 2002; 81:313-18.

Digiulio DB, Romero R, Amogan H P, Kusanovic JP, Bik EM, Gotsch F, Kim CJ, Erez O, Edwin S, Relman D. A. Microbial prevalence, diversity and abundance in amniotic fluid during preterm labour: a molecular and culture-based investigation. PLOS One. 2008; 26:e3056.

Dortbudak O, Eberhardt R, Ulm M, Persson GR. Periodontitis, a marker of risk in pregnancy for preterm birth. J Clin Periodontol. 2005; 32: 45-52.

Farrell S, Ide M, Wilson RF. The relationship between maternal periodontitis, adverse pregnancy outcome and miscarriage in never smokers. J Clin Periodontol. 2006; 33:115-20.

Feinstein AR. Principles of Medical Statistics. 1. ed. Boca Raton: Chapman \& Hall/CRC; 2002.

Fox $\mathrm{H}$, Langley FA. Leucocytic infiltration of the placenta: a clinical-pathological study. J Clin Pathol. 1971; 24:480.

Fox H. Pathology of the Placenta. 1st London: W. B. Saunders; 1978.

Fox H, Sebire NJ. Pathology of the placenta. London: Saunders (Elsevier); 2007.

Gazolla C, Ribeiro A, Moysés MR, Oliveira LAM, Pereira LJ, Sallum AW. Evaluation of the incidence of preterm low birth weight in patients undergoing periodontal therapy. J Periodontol. 2007; 78:842-48.

Glesse S, Saba-Chujfi E, Carvalho A, Pacheco JJ, Salazar F. Estudo epidemiológico da influência da doença periodontal no trabalho de parto pré-termo na cidade brasileira de Santa Cruz do Sul - RS. Rev Port Estomat Med Dent Cir Maxilofacial. 2004; 45:205-14. 
Goepfert AR, Jeffcoat MK, Andrews WW, Faye-Petersen O, Cliver SP, Goldenberg RL, Hauth JC. Periodontal disease and upper genital tract inflammation in early spontaneous preterm birth. Obstet Gynecol. 2004; 104:777-83.

Goldman AS, Schmalstieg FC. The pathogenesis of chorioamnionitis. J Pediatr. 2008; 153:3-4.

Gomes-Filho IS, Cruz SS, Rezende EJC, Silveira BBB, Trindade SC, Passos JS, Freitas COT, Cerqueira EMM, Santos CAST. Periodontal status as predictor of prematurity and low birth weight. J Public Health Dent. 2006; 66:295-98.

Gonçalves TFT, Chaiworapongsa T, Romero R. Intrauterine infection and prematurity. Ment Retard Dev Disabil Res Rev. 2002; 8:3-13.

Gontijo GR, Saba-Chujfi E, Carvalho A, Pacheco JJ, Salazar F. Estudo epidemiológico da prevalência da doença periodontal em mulheres com parto prétermo na cidade brasileira de Divinópolis-MG. Rev Port Estomatol Med Dent Cir Maxilofacial. 2006; 47:203-09.

Grossi SG, Genco RJ, Machtei EE, Ho AW, Koch G, Dunford R et al. Assessment of risk for periodontal disease. II. Risk indicators for alveolar boné loss. J Periodontol. 1995; 66:23-29.

Guimarães NA, Silva-Mato A; Cota LOM, Siqueira FM, Costa FO. Maternal periodontal disease and preterm on extreme preterm birth: An ordinal logistic regression analysis. J Periodontol. 2010; 81:350-58.

Haffajee AD, Socransky SS. Microbial etiological agents of destructive periodontal diseases. Periodontol 2000. 1994; 5:78-11.

Haffajee AD, Socransky SS. Relationship of cigarette smoking to the subgingival microbiota. J Clin Periodontol. 2001; 28:377-88.

Haffajee AD, Socransky SS. Microbiology of periodontal diseases: introduction. Periodontol 2000. 2005; 38:9-12.

Han YW, Ikegami A, Bissada NF, Herbst M, Redline RW, Ashmead GG. Transmission of an uncultivated Bergeyella strain from the oral cavity to amniotic fluid in a case of preterm birth. J Clin Microbiol. 2006; 44:1475-83. 
Han YW, Shen T, Chung P, Buhimschi IA, Buhimschi CS. Uncultivated Bacteria as Aetiologic Agents of Intra-amniotic Inflammation Leading to Preterm Birth. J Clin Microbiol. 2009; 47:38-47.

Han YW, Fardini Y, Chen C, lacampo, KG, Peraino VA, Shamonki JM, Redline RW. Term stillbirth caused by oral Fusobacterium nucleatum. J Obstet Gynecol. 2010; 115 (part 2):442-45.

Haram K, Mortensen JHS, Wollen AL. Preterm delivery: an overview. Acta Obstet Gynecol Scand. 2003; 82:687-04.

Hasegawa K, Furuich Y, Shimotsu A, Nakamura M, Yoshingaga M, Kamitomo M, Hatae M, Maruyama I, Izumi Y. Associations between systemic status, periodontal status, serum cytokine levels, and delivery outcomes in pregnant women with a diagnosis of threatened premature labor. J Periodontol. 2003; 74:1764-770.

Hasegawa-Nakamura K, Tateishi F, Nakamura T, Nakajima Y, Kawamata K, Douchi T, Hatae M, Noguchi K. The possible mechanism of preterm birth associated with periodontopathic Porphyromonas gingivalis. J Periodont Res. 2011:1-9.

Henriques LWP. A influência da doenca periodontal no parto pré-termo: Estudo epidemiológico realizado na Associação Beneficente Pró-Matre, em Vitória-ES. [Dissertação (Mestrado em Odontologia)]. Campinas: CPO. São Leopoldo Mandic. Campinas; 2003.

Hill GB. Investigating the source of amniotic fluid isolates of fusobacteria. Clin Infect Dis. 1993; 6:423-24.

Hill GB. Preterm birth: association with genital and possible oral microflora. Ann Periodontol. 1998; 3:222-32.

Hillier SL, Nungent RP, Eschenbach DA, Krhon MA,Gibbs RS, Martin DH et al. Association between bacterial vaginosis and preterm delivery of a low birthweight infant. The vaginal infections and premature study. N Eng J Med. 1995; 333:1737742.

Hoffman HJ, Bakkteig LS. Risk factors associated with the occurrence of preterm birth. Clin Obstet Gynecol. 1984; 27:539-52.

Holbrook WP, Óskarsdóttir A, Fridjónsson T, Einarsson H, Hauksson A, Geirsson RT. No link between low-grade periodontal disease and preterm birth: a pilot study in a healthy Caucasian population. Acta Odontol Scand. 2004; 62:177-79. 
Jadhav A, Belfort MA, Dildy GA. Eikenella corrodens chorioamnionitis: modes of infection? Am J Obstet Gynecol.2009:e4-e5.

Jarjoura K, Devine PC, Perez-Deelboy A, Herrera-Abreu M, D'alton M, Papapanou PN. Markers of periodontal infection and preterm birth. Am J Obstet Gynecol. 2005; 192:513-19.

Jeffcoat MK, Geurs NC, Reddy MS, Cliver SP, Goldenberg RL, Hauth JC. Periodontal infection and preterm birth: results of a prospective study. J Am Dent Assoc. 2001a; 32:875-80.

Jeffcoat MK, Geurs NC, Reddy MS, Goldenberg RL, Hauth JC. Current evidence regarding periodontal disease as a risk factor in preterm birth. Ann Periodontol. 2001b; 6:183-88.

Jeffcoat MK, Hauth JC, Geurs NC, Reddy MS, Cliver SP, Hodgkins PM, Goldenberg $\mathrm{RL}$. Periodontal disease and preterm birth: results of a pilot intervention study. $\mathrm{J}$ Periodontol. 2003; $4: 1214-218$.

Khader Y, Ta'Ani Q. Periodontal diseases and the risk of preterm birth and low birth weight? A meta-analysis. J Periodontol. 2005; 76:161-65.

Khader Y, Al-Shishani L, Obeidat B, Khassawneh M, Burgan S, Amarin ZO, Alomari M, Alkafajei A. maternal periodontal status and preterm low birth weight delivery: a case-control study. Arch Gynecol Obstet. 2009; 279:165-69.

Katz J Chegini N, Shiverick KT, Lamont RL. Localization of P.gingivalis in preterm delivery placenta. J Dent Res. 2009; 88:575-78.

Kent ASH, Sullivan MHF, Elder MG. Transfer of cytokines through human fetal membranes. J Reprod Fertil. 1994;100:81-4.

Kierse MJ. Na evaluation of formal risk scoring for preterm birth. AM J Perinat. 1989; 6:226-33.

Kloos K, Vogel M. Patología del Período Perinatal: Fundamento, métodos y primeros resultados de una quiematopatología, Barcelona: Salvat; 1978.

Kornman KS, Löesche WJ. The subgingival microbial flora during pregnancy. J Periodontol Res. 1980; 15:111-22. 
Kramer MS. The epidemiology of adverse pregnancy outcomes: an overview. J Nutr. 2003; 133(5 Suppl 2):S1592-596.

Kunnen A, Blaauw J, van Doormaal JJ, van Pampus MG, van der Schans CP, Aarnoudse JG et al. Women with a recent history of early-onset pre-eclampsia have a worse periodontal condition. J Clin Periodontol. 2007; 34:202-07.

Lee SD, Romero R, Jung H, Park C W, Park JS, Yoon BH. The intensity if the fetal inflammatory response in intraamniotic inflammation with and without microbial invasion of the amniotic cavity. Am J Obstet Gynecol., 2007;197:e1-6.

Leon R, Silva N, Ovalle A, Chaparro A, Ahumada A, Gajardo M et al. Detection of Porphyromonas gingivalis in the amniotic fluid in pregnant women with a diagnosis of threatened premature labor. J Periodontol. 2007; 78:1249-255.

Libby $\mathrm{P}$, Egan D, Skarlatos S. Roles of infectious agents in atherosclerosis and restenosis: an assessment of the evidence and need for future research. Circulation. 1997; 96:4095-103.

Lieff S, Boggess KA, Murtha AP, Jared $\mathrm{H}$, Madianos PN, Moss $\mathrm{K}$ et al. The oral conditions and pregnancy study: periodontal status of a cohort of pregnant women. $\mathrm{J}$ Periodontol. 2004; 75:116-26.

Lindemann RA, Economou JS, Rothermel H. Production of interleukin-1 and tumor necrosis factor by human peripheral monocytes activated by periodontal bacteria and extracted lipopolysaccharides. J. Dent Res. 1988; 67:1131-135.

Löe H, Theilade E, Jensem SB. Experimental gingivitis in man. J Periodontol. 1965; 36:177-87.

Löe $\mathrm{H}$, Anerud A, Boysen H, Morrison E. Natural history of periodontal disease in man. Rapid moderate and no loss of attachment in Sri Lankan laborers 14 to 46 years of age. J Clin Periodontol 1986; 13:431-45.

Loesche WJ. Bacterial mediators in periodontal disease. Clin Infect Dis. 1993; 16: 4 (Suppl): S203-10.

Lohsoonthorn V, Kungsadalpipob K, Chanchareonsook P, Limpongsanurak S, Vanichjakvong O, Sutdhibhisal S et al. Is Maternal Periodontal Disease a Risk Factor for Preterm Delivery? Am J Epidemiol. 2009; 169:731-39. 
Lopatin DE, Kornman KS, Loesche WJ. Modulation of immunoreactivity to periodontal disease-associated microorganisms during pregnancy. Infect Immun. 1980; 28:713-18.

López NJ, Smith PC, Gutierrez J. Higher risk of preterm birth and low birth weight in women with periodontal disease. J Dent Res. 2002a; 81:58-63.

López NJ, Smith PC, Gutierrez J. Periodontal therapy may reduce the risk of preterm low birth weight in women with periodontal disease: a randomized controlled trial. J Periodontol. 2002b; 73:911-24.

López NJ, Da Silva I, Ipinza J, Gutiérrez J. Periodontal therapy reduces the rate of preterm low birth weight in women with pregnancy-associated gingivitis. J Periodontol. 2005; 76: 11 (Suppl.):2144-153.

Louro PM, Fiori HH, Louro Filho P, Steibel J, Fiori RM. Doença periodontal na gravidez e baixo peso ao nascer. J Pediatr. 2001; 77:23-28.

Lunardelli AN, Peres MA. Is there an association between periodontal disease, prematurity and low birth weight? A population-based study. J Clin Periodontol. 2005:1-9.

Macones GA, Pary S, Nelson DB, Strauss JF, Ludmir J, Cohen AW et al. Tratment of localized periodontal disease in pregnancy does not reduce the occurrence of preterm birth: results from the Periodontal Infections and Prematurity Study (PIPS). Am J Obstet Gynecol. 2010; 202: 147.e1-8

Madianos PN, Lieff S, Murtha AP, Boggess KA, Auten Jr. RL, Beck JD et al.. Maternal periodontitis and prematurity. Part II: maternal infection and fetal exposure. Ann Periodontol. 2001; 6:175-82.

Marakoglu I, Gursoy UK, Marakoglu K, Cakmak H, Ataoglu T. Periodontitis as a risk factor for preterm low birth weight. Yonsei Med J. 2008; 49:200-203.

Marin C, Segura-Egea JJ, Martinex-Sahuquillo A, Búllon P. Correlation between infant birth weight and mother's periodontal status. J Clin Periodontol. 2005; 32:29904.

Mass SB, Brennan JP, Silverman N, Van Hoeven $\mathrm{KH}$. Association between a shift in vaginal flora on Papanicolaou smear and acute chorioamnionitis and preterm delivery. Diagn Cytopathol. 1999; 21:7-9. 
Mcdonald HMV, O'Loughlin JA, Vigneswaran R, Jolley PT, McDonald PJ. Bacterial vaginosis in pregnancy and efficacy os short-course oral metronidazole treatment: a randomized controlled trial. Obstet Gynecol. 1994; 84:343-48.

McGaw T. Periodontal diseases and preterm delivery of low-birth-weight infants. J Can Dent Assoc. 2002; 68:165-69.

Menon R, Fortunato SJ. Infection and the role of inflammation in preterm premature rupture of the membranes. Review. Best Pract Res Clin Obstet Gynaecol. 2007; 21:467-78.

Merçon-De-Vargas, P.R. Contribuição do estudo morfológico dos anexos fetais para o entendimento dos problemas reprodutivos, sobretudo os do III trimestre da gestação humana, em especial quanto ao valor diagnóstico dos achados morfológicos: estudo anátomo-clínico de 962 casos. [Tese (Doutorado em Anatomia Patológica Médica)]. Belo Horizonte: Universidade Federal de Minas Gerais, Belo Horizonte; 1992.

Merçon-De-Vargas PR, Pagani AD, Ramos PGP, Novaes PB. Infecção cervicovaginal em gestantes: qual a dimensão do problema? VII EMGO - Minas Gerais. Anais do VII Encontro Mineiro de Ginecologia e Obstetrícia. Poços de Caldas; 2000.

Meurman JH, Furuholm J, Kaaja R, Rintamaki H, Tikkanem U. Oral health in women with pregnancy and delivery complications. Clin Oral Invest. 2006; 20: 96-101.

Michalowicz BS, Hodges JS, DiAngelis AJ, Lupo VR, Novak MJ, Ferguson JE et al. Treatment of periodontal disease and the risk of preterm birth. New Engl $\mathrm{J}$ Med. 2006; 355:1885-894.

Michalowicz BS, Hodges JS, Novak MJ, Buchanan W, Diangelis AJ, Papapanou, PN et al. Change in Periodontitis during Pregnancy and the Risk of Pre-term Birth and Low Birthweight. J Clin Periodontol. 2009; 36:308-14.

Mitchell-Lewis D, Engebretson SP, Chen J, Lamster IB, Papapanou PN. Periodontal infections and pre-term birth: early findings from a cohort of young minority women in New York. Eur J Oral Sci. 2001; 109:34-9.

Mokeem SA, Molla GGN, Al-Jawair TS. The prevalence and relationship between periodontal disease and pre-term low birth weight infants at King Khalid University Hospital in Riyadh, Saudi Arabia. J Contemp Dent Pract. 2004; 5:1-12. 
Moliterno LFM, Monteiro B, Figueredo CMS, Fischer RG. Association between periodontitis and low birth weight: a case-control study. J Clin Periodontol. 2005; 32:886-90.

Moore S, Ide M, Wilson RF, Coward PY, Borkowska E, Baylis R et al. Periodontal health of London women during early pregnancy. Brit Dent J. 2001; 191:570-73.

Moore S, Ide M, Coward PY, Randhava M, Borkowska E, Baylis R et al. A prospective study to investigate the relationship between periodontal disease and adverse pregnancy outcome. B Dent J. 2004; 197:251-58.

Moore S, Randhava M, Ide M. A case-control study to investigate an association between adverse pregnancy outcome and periodontal disease. J Clin Periodontol. 2005; 32:1-5.

Moreu G, Téllez L, González-Jaranay M. Relationship between maternal periodontal disease and low-birth-weight pre-term infants. J Clin Periodontol. 2005; 32:622-27.

Morrison JC. Preterm birth: a puzzle worth solving. Obstet Gynecol. 1990; 76 (1Suppl):5S-12.

Moss KL, Beck, JD, Offenbacher S. Clinical risk factors associated with incidence and progression of periodontal conditions in pregnant women. J Clin Periodontol. 2005; 32:492-98.

Nabet C, Lelong N, Colombier M-L, Sixou M, Musset A-M, Goffinet F et al. Maternal periodontitis and the causes of preterm birth: the case-control Epipap study. J Clin Periodontol. 2010; 37:37-5.

Naeye RL, Tafari N. Risk factors in pregnancy and diseases of the fetus and newborn. 1 ed. Baltimore: Williams \& Wilkins, 1983. 282 p.

Newnham JP, Newnham IA, Ball CM, Wright M, Pennel CE, Swain J et al. Treatment of periodontal disease during pregnancy. Obstet Gynecol. 2009; 114:1239-248.

Noack B, Klinngenberg J, Weigelt J, Hoffmann T. Periodontal status and preterm low birth weight: a case control study. J Periodontol. 2005; 40:339-45.

Nordenvall M, Sandstedt B. Chorioamnionitis in relation to gestational outcome in a Swedish population. Eur J Obstet Gynecol Reprod Biol. 1990; 36:59-7. 
Offenbacher S, Heasman PA, Collins JG. Modulation of host PGE 2 secretion as a determinant of periodontal disease expression. J Periodontol. 1993; 64:432-44.

Offenbacher S, Katz V, Fertik G, Collins J, Boyd D, Maynor G et al. Periodontal infection as a possible risk factor for preterm low birth weight. J Periodontol. 1996a; 67:1103-113.

Offenbacher S. Periodontal diseases: Pathogenesis. Ann Periodontol. 1996b; 1:82178.

Offenbacher S, Lieff S, Boggess KA, Murtha AP, Madianos PN, Champagne CM et al. Maternal periodontitis and prematurity. Part I: Obstetric outcome of prematurity and growth restriction. Ann Periodontol. 2001; 6:164-74.

Offenbacher S, Boggess K A, Murtha AP, Jared HL, Lieff S, Mckaig RG et al. Progressive periodontal disease and risk of very preterm delivery. Obstet Gynecol. 2006; 107:29-36.

Offenbacher S, Beck JD, Jared HL, Mauriello SM, Mendoza LC, Couper DJ et al. Effects of periodontal therapy on rate of preterm delivery. Obstet Gynecol. 2009; 114: 551-59.

Oittinen J, Kurki T, Kekki M, Kuusisto M, Pussinen P, Vilkuna-Rautiainen $\mathrm{N}$ et al. Periodontal disease and bacterial vaginosis increase the risk for adverse pregnancy outcome. Infec Dis Obstet Gynecol. 2005; 13:213-16.

O'Neil TCA. Plasma female sex-hormone levels and gingivitis in pregnancy. J Periodontol. 1979; 50:279-82.

Ovalle A, Gamonal J, Martínez MA, Silva N, Kakarieka E, Fuentes A, et al. Relación entre enfermedad periodontal, infección bacteriana ascendente y patologia placentária con parto prematuro. Rev Méd Chile. 2009; 137:504-14.

Page RC. The role of inflammatory mediators in the pathogenesis of periodontal disease. J Periodontol Res. 1991; 26:230-42.

Page RC. Periodontal diseases: a new paradigm. J Den Educ. 1998; 62:812-21.

Park CW, Moon KC, Park JS, Jun JK, Romero R, Yoon BH. The involvement of human amnion in histologic chorioamnionitis is an indicator that a fetal and an intraamniotic inflammatory response is more likely and severe: clinical implications. Placenta. 2009; 30:56-61. 
Paster BJ, Olsen I, Aas JA, Dewhirst FE. The breadth of bacterial in the human periodontal pockets and other oral sites. Periodontol 2000. 2006; 42:80-87.

Paster BJ, Dewhirst FE. Molecular Microbial Diagnosis. Periodontol 2000. 2009; $51: 38-44$.

Persson R, Hitti J, Verhelst R, Vaneechoutte M, Persson R, Hirschi R et al. The vaginal microflora in relation to gingivitis. BMC Infect Dis. 2009; 9:1-8.

Pitiphat W, Joshipura KJ, Gillman MW, Williams PL, Douglass CW, Rich-Edwards JW. Maternal periodontitis and adverse pregnancy outcomes. Community Dent Oral Epidemiol. 2008; 36:3-11.

Polyzos NP, Polyzos I, Mauri D, Tzioras S, Tsappi M, Cortinovis I et al. Effect of periodontal disease treatment during pregnancy on pretrm birth incidence: ametaanalysis of randomized trials. Am J Obstet Gynecol. 2009; 35:225-32.

Radnai M, Gorzó I, Nagy E, Urbán E, Novák T, Pál A. A possible association between preterm birth and early periodontitis: pilot study. J Clin Periodontol. 2004; 31:736-41.

Rakoto-Alson S, Tenenbaum H, Davideau JL. Periodontal diseases, preterm births and low birth weight: findings from a homogeneous cohort of women in Madagascar. J Periodontol. 2010; 81:205-13.

Rajapakse PS, Nagarathne M, Chandrasekra KB, Dasanayake AP. Periodontal disease and prematurity among non-smoking Sri Lankan women. J Dent Res. 2005; 84:274-77.

Richée EL, Boggess KA, Lieff S, Murtha AP, Auten RL; Beck JD et al. Periodontal disease increases the risk of preterm delivery among preeclamptic women. Ann Periodontol. 2002; 7:95-101.

Romero R, Ghidini A, Mazor M, Behnke E. Microbial invasion of the amniotic cavity in premature rupture of membranes. Clin Obstet Gynecol. 1991; 34:769-78.

Romero R, Espinoza J, Gonçalves LF, Kusanovic JP, Friel LA, Nien JK. Inflammation in preterm and term labour and delivery. Review. Semin Fetal Neonatal Med. 2006; 11:317-26. 
Romero R, Gotsch F, Pineles B, Kusanovic JP. Inflammation in pregnancy: its roles in reproductive physiology, obstetrical complications, and fetal injury. Review. Nutr Rev. 2007a; 65:12 (pt 2) S194-202.

Romero R, Espinoza J, Gonçalves L F, Kusanovic JP, Friel LA, Hassan S. The role of inflammation and infection in preterm birth. Review. Semin Reprod Med. 2007b; 25:21-39.

Ryu JI, Oh KJ, Yang HJ, Choi BK, Ha JE, Jin BH et al. Health behaviors, periodontal conditions, and periodontal pathogens in spontaneous preterm birth: a case-control study in Korea. J Periodontol. 2010; 81:855-63.

Sacks GP, Studena K, Sargent IL, Redman CWG. Normal pregnancy and preeclampsia both produce inflammatory changes in peripheral blood leucocytes akin to those of sepsis. Am J Obstet Gynecol. 1998; 179:80-6.

Sakamoto M, Umeda M, Benno Y. Molecular analysis of human oral microbiota. J Periodont Res. 2005; 40:277-85.

Santos CMRO. Autocoleta vaginal e diário de hábitos de vestuário, higiene, práticas sexuais e sintomas como instrumentos para o estudo da microbiota, citolise e inflamação vaginais. [Dissertação (Mestrado em doenças infecciosas)]. Vitória: Universidade Federal do Espírito Santo; 2009.

Santos-Pereira SA, Giraldo PC, Saba-Chujfi E, Amaral RLG, Morais SS Fachini AM et al. Chronic periodontitis and pre-term labour in Brazilian pregnant women: an association to be analysed. J Clin Periodontol. 2007; 34:208-13.

Scannapieco FA, Bush RB, Paju S. Periodontal disease as a risk factor for adverse pregnancy outcomes. A systematic review. Ann Periodontol. 2003; 8:70-8.

Schenkein HV. Finding genetic risk factors for periodontal diseases: is the climb worth the view? Periodontol 2000. 2002; 30:79-90.

Seong HS, Lee SE, Knag JH, Romero R, Yoon BH. The frequency of microbial invasion of the amniotic cavity and histological chorioamnionitis in women at term with intact membranes in the presence or absence of labor. Am J Obstet Gynecol. 2008; 199:375. e1-5.

Sharma R, Maimanuku LR, Morse Z, Pack AR. Preterm low birth weights associated with periodontal disease in the Fiji Islands. Int Dent J. 2007; 57, 257-60. 
Shiono PH, Klebanoff MA, Rhoads CG. Smoking and drinking during pregnancy. J Am Med Assoc. 1986; 255:82-84.

Shub A, Wong C, Jennings B, Swain J, Newnham JP. Maternal Periodontal Disease and Perinatal Mortality. Aust New Zeal J Obstetr Gynecol. 2009; 49:130-36.

Skuldbol T, Johansen KH, Dahlén G, Stoltze K, Holmstrup P. Is pre-term labour associated with periodontitis in a Danish maternity ward? J Clin Periodontol. 2006; 33:177-83.

Simões JA, Giraldo PC, Cecatti JG, Camargo RPS; Faundes A. Complicações perinatais em gestantes com e sem vaginose bacteriana. Rev Bras Ginecol Obstet. $1998 ; 20: 437-41$.

Sinasc. Sistema Nacional de Nascidos Vivos. Ministério da Saúde. Rede Interagencial de Informações para a Saúde. Indicadores e dados básicos para a saúde - 2007 (IDB-2007). Tema do ano: nascimento no Brasil. Disponível em: <http:/tabnet.datasus.gov.br/cgi/idb2007/tema.pdf> Acesso em: 05 ago. 2010.

Srinivasan U, Misra D, Marazita MJ, Foxman B. Vaginal and oral microbes, host genotype and preterm birth. Med Hypotheses. 2009; 73:963-75.

Socransky SS, Haffajee AD. Evidence of bacterial etiology: a historical perspective. Periodontol 2000. 1994; 5:7-25.

Socransky SS, Haffajee AD. The nature of periodontal diseases. Ann Periodontol. $1997 ; 2: 3-10$.

Socransky SS, Haffajee Ad, Cugini MA, Smith C, Kent Jr RL. Microbial complexes in subgingival plaque. J Clin Periodontol. 1998; 25:134-44.

Socransky SS, Haffajee A.D. Periodontal microbial ecology. Periodontol 2000. 2005; 38:135-87.

Stashenko P, Dewhirst FE, Peros WJ, Kent RL, Ago JM. Synergistic interactions between interleukin-1, tumor necrosis factor and lymphotoxin in bone resorption. $J$ Immunol. 1987; 138:1464-468.

Sweet RL, Gibbs RS. Infection Diseases of the Female Genital tract. 4.ed. Philadelphia: Pippincot William \& Willkins; 2002. 187p. 
Swenson HM. The effect of smoking on plaque formation. J Periodontol. 1979; 50:146-47.

Tarannum F, Faizuddin M. Effect of periodontal therapy on pregnancy outcome in women affected by periodontitis. J Periodontol. 2007; 78:2095-103.

Tolockiene E, Morsing E, Holst E, Herbst A, Ljungh A, Svenningsen, $\mathrm{N}$ et al. Intrauterine infection may be a major cause of stillbirth in Sweden. Acta Obstet Gynecol Scand. 2001; 80:511-18.

Toygar HU, Seydaoglu G, Kurklu S, Guzeldemir E, Arpak N. Periodontal health and adverse pregnancy outcome in 3,576 Turkish women. J Periodontol. 2007; 78:2081094.

Tukey JW. Exploratory data analysis. 1ed. Massachussetts, Addison-Wesley Publishing Company; 1977.

Urbán E, Radnai, Novák T, Gorzó I, Pál A, Nagy E. Distribution of anaerobic bacteria among pregnant periodontitis patients who experience preterm delivery. Anaerobe. 2006; 12:52-7.

Vergnes JN, Sixow M. Preterm low birth weight and maternal periodontal status: a meta-analysis. Am J Obstet Gynecol. 2007; 196:135.e1-135.e7.

Vettore MV. Periodontal infection and adverse pregnancy outcomes: a systematic review of epidemiological studies. Cad Saúde Pública. 2006; 22: 2041-053.

Vettore MV, Leão AT, Leal MC, Feres M, Sheiham A. The relationship between periodontal disease and preterm low birth weight: clinical and microbiological results. J Periodont Res. 2008; 43:615-26.

Vittek J Rappaport SC, Gordon GG, Munnangi PR, Southren AL. Concentration of circulating hormones and metabolism of androgens by human gingiva. J Periodontol. 1979; 50:254-64. 
Watts DH, Krohn MA, Hillier SL, Eschenbach DA. The association of occult amniotic fluid infection with gestational age and neonatal outcome among women in preterm labor. Obstet Gynecol. 1992; 79:351-57.

Wigglesworth JS. Perinatal pathology. Series Major Problems in Pathology. v. 15. Philadelphia : W.B. Saunders; 1984.

Williams RC, Offenbacher S. Periodontal medicine: The emergence of a new branch of periodontology. Periodontol 2000. 2000; 23:9-12.

Williams MC, O'brien WF, Nelson RN, Spellacy WN. Histological chorioamnionitis is associated with fetal growth restriction in term and preterm infants. Am J Obstet Gynecol. 2000; 183:1094-99.

Williams CECS, Davenport ES, Sterne JAC, Sivapathasundaram V, Fearne JM, Curtis MA. Mechanisms of risk in preterm low birth weight infants. Periodontol 2000. 2000; 23:142-50.

Wimmer G, Pihlstrom BL. A critical assessment of adverse pregnancy outcome and periodontal disease. J Clin Periodontol. 2008; 35(Suppl.8): 380-97.

Yoon BH, Romero R, Kim K, Kim EC, Kim T, Park, J.S et al. Clinical implications of detection of Ureaplasma urealyticum in the amniotic cavity with the polymerase chain reaction. Am J Obstet Gynecol. 2000; 183:1130-137.

Xiong X, Buekens P, Fraser WD, Beck J, Offenbacher S. Periodontal disease and adverse pregnancy outcomes: a systematic review. Brit J Obstet Gynecol. 2006; 113:135-43. 


\section{APÊNDICE A}

\section{TERMO DE CONSENTIMENTO LIVRE E ESCLARECIDO}

Você está sendo convidado para participar da pesquisa: AVALIAÇÃo CLÍNICA E MICROBIOLÓGICA DA DOENÇA PERIODONTAL E DA PLACENTA DE PARTURIENTES ATENDIDAS NO HUCAM sob a responsabilidade dos pesquisadores Alfredo Carlos Rodrigues Feitosa e Paulo Roberto Merçon de Vargas. Nesta pesquisa nós estamos buscando entender se as bactérias da boca presentes nas gengivas inflamadas (bolsa periodontal) são encontradas na secreção vaginal ou se elas podem ser encontradas na placenta (nas membranas, no celoma ou no espaço interviloso). $O$ pesquisador, Prof. Dr. Alfredo Carlos Rodrigues Feitosa irá obter este Termo de Consentimento junto a você durante o trabalho na Maternidade do HUCAM (Hospital Universitário Cassiano Antonio de Moraes).

Na sua participação você permitirá durante a sua internação a coleta da secreção vaginal por meio de swab e tocólise (toque) realizado pelo obstetra ou pelo residente da Maternidade. Após o parto, e até 12 horas, o pesquisador Dr. Alfredo Carlos Rodrigues Feitosa realizará duas a quatro coletas da placenta junto ao Serviço de Patologia do HUCAM. Depois ele retornará ao leito da Maternidade, no período de até 72 horas, para coletar quatro amostras de placa dental (quatro dentes), por meio de dois cones de papel absorvente estéreis colocados dentro da bolsa periodontal, e fará o exame clínico da cavidade bucal para identificar se a gengiva está inflamada ou não, por meio do uso de sonda periodontal (instrumento metálico para diagnóstico de rotina) e enumerar os dentes presentes. Em nenhum momento da pesquisa você será identificado. Os resultados da pesquisa serão publicados e ainda assim a sua identidade será preservada. Você não terá nenhum gasto e ganho financeiro por participar na pesquisa.

Os riscos da coleta das amostras de placa dental da gengiva inflamada não existem, pois apenas ocorre leve sensação de espetar a gengiva com os cones de papel. Durante o exame clínico com a sonda periodontal, leve dor após a colocação da mesma, como parte da rotina de diagnóstico dos pacientes no Serviço de Periodontia da UFES. Os benefícios desta pesquisa são extremamente interessantes, pois permitirá descobrir quais as parturientes que estão com inflamação gengival (bolsa periodontal) para que as mesmas sejam encaminhadas pelo pesquisador Dr. Alfredo Carlos Rodrigues Feitosa para receber tratamento periodontal gratuito no Serviço de Periodontia da UFES. Outro detalhe é conhecermos quais são as bactérias da boca que podem esta vivendo na cavidade vaginal, e se elas também estão na parte interna (espaço interviloso ou celoma da placenta). Você é livre para parar de participar a qualquer momento sem nenhum prejuízo para a senhora. Uma cópia deste Termo de Consentimento Livre e Esclarecido ficará com a senhora.

Qualquer dúvida a respeito da pesquisa a senhora poderá entrar em contato com: Pesquisador Prof. Dr. Alfredo Carlos Rodrigues Feitosa

Av, Hugo Musso, 958 apto: 701 Praia da Costa CEP: 29101-280 Vila Velha-ES

Tel: (27) 3299-5766/3335-7273/3335-7276 ou 9999-4793

Vitória, de de $200 \ldots \ldots$

\section{Assinatura dos pesquisadores}

Eu aceito participar do projeto citado acima, voluntariamente, após ter sido devidamente esclarecido:

Nome do participante da pesquisa 
APÊNDICE B 
A. Gel em agarose (1\%) de alguns produtos do PCR de Porhyromonas gingivalis.

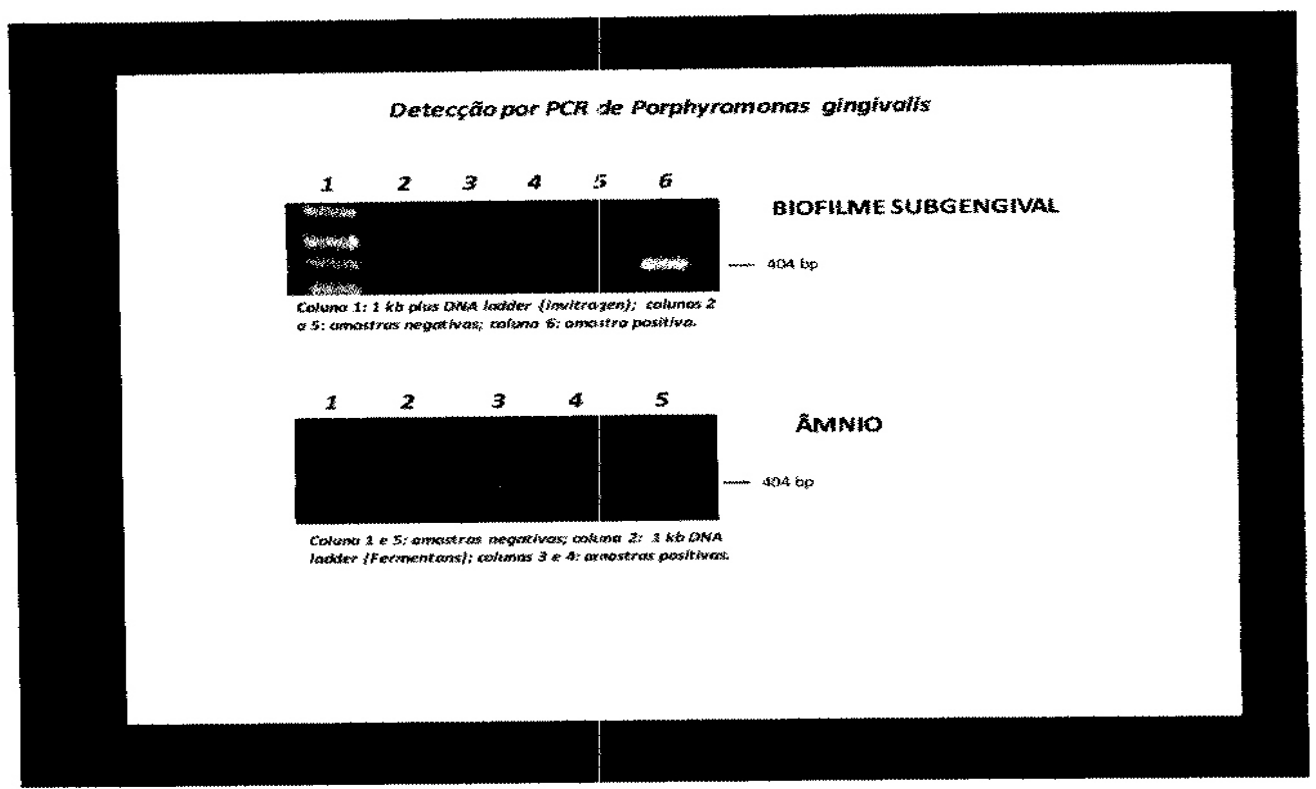




\section{APÊNDICE C}

Ficha Clínica Periodontal para exame clínico bucal nas puérperas.




